OPEN ACCESS

Edited by:

Banasri Hazra,

Jadavpur University, India

Reviewed by:

Sutapa Biswas Majee,

NSHM Knowledge Campus, India

Nora Gray,

Oregon Health and Science University,

United States

${ }^{*}$ Correspondence:

Ming Gao

gaoming@mukogawa-u.ac.jp

Tonghua Liu

thliu@vip.163.com

Specialty section:

This article was submitted to

Ethnopharmacology,

a section of the journal

Frontiers in Pharmacology

Received: 31 May 2020

Accepted: 14 August 2020

Published: 04 September 2020

Citation:

Sun B, Wu L, Wu Y, Zhang C, Qin L, Hayashi M, Kudo M, Gao M and Liu T

(2020) Therapeutic Potential of Centella asiatica and

Its Triterpenes: A Review.

Front. Pharmacol. 11:568032. doi: 10.3389/fphar.2020.568032

\section{Therapeutic Potential of Centella asiatica and Its Triterpenes: A Review}

\author{
Boju Sun ${ }^{1}$, Lili Wu ${ }^{2}$, You $W u^{1}$, Chengfei Zhang ${ }^{1}$, Lingling Qin ${ }^{3}$, Misa Hayashi ${ }^{4}$, \\ Maya Kudo ${ }^{4}$, Ming Gao ${ }^{4 *}$ and Tonghua Liu ${ }^{{ }^{*}}$
}

1 Second Clinical Medical College, Beijing University of Chinese Medicine, Beijing, China, ${ }^{2}$ Key Laboratory of Health Cultivation of the Ministry of Education, Beijing University of Chinese Medicine, Beijing, China, ${ }^{3}$ Technology Department, Beijing University of Chinese Medicine, Beijing, China, ${ }^{4}$ School of Pharmaceutical Sciences, Mukogawa Women's University, Hyogo, Japan

Centella asiatica (also known as Centella asiatica (L.) Urb. or Gotu kola) is a traditional Chinese medicine with extensive medicinal value, which is commonly used in Southeast Asian countries. This study aimed to summarize the effects of $C$. asiatica and its main components on neurological diseases, endocrine diseases, skin diseases, cardiovascular diseases, gastrointestinal diseases, immune diseases, and gynecological diseases, as well as potential molecular mechanisms, to study the pathological mechanism of these diseases based on the changes at the molecular level. The results showed that $C$. asiatica and its triterpenoids had extensive beneficial effects on neurological and skin diseases, which were confirmed through clinical studies. They exhibited anti-inflammatory, antioxidative stress, anti-apoptotic effects, and improvement in mitochondrial function. However, further clinical studies are urgently required due to the low level of evidence and lack of patients.

Keywords: anti-apoptosis, anti-inflammatory, anti-oxidative stress, Centella asiatica, triterpenoids

\section{INTRODUCTION}

Centella asiatica, also known as Centella asiatica (L.) Urb. or Gotu kola, is an herb used in traditional Chinese medicine in China and Southeast Asian countries to treat a variety of diseases. The earliest records of C. asiatica in China can be retraced back to "su wen shi" and "zheng lei ben cao" in Song Dynasty. It is described as follows: "Centella asiatica, bitter, cold, nontoxic. Suitable for use in fever and skin conditions." Another source "ming jia fang xuan" lists the herb for use in treating Gilles de la Tourette syndrome in children. A large number of animal and cell experiments have been performed on C. asiatica and its active components. Centella contains several pentacyclic triterpenoids, including asiaticoside, brahmoside, and madecassic acid, along with other constituents such as centellose, centelloside, and madecassoside (Murray and Pizzorno, 2012; Singh and Rastogi, 1968; Singh and Rastogi, 1969). The main chemical components responsible for its pharmacological activity are triterpenes, mostly asiaticoside, asiatic acid, madecassoside, and madecassic acid (Figure 1).

Madecassoside (pubchem CID: 131801373) is a pentacyclic triterpene saponin from C. asiatica with multiple pharmaceutical activities. It has a molecular formula of $\mathrm{C} 48 \mathrm{H} 78 \mathrm{O} 20$ and a molecular 


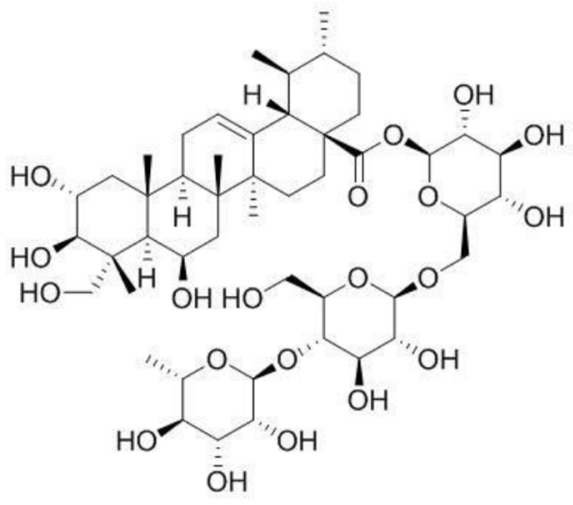

Madecassoside

$\mathrm{C} 48 \mathrm{H} 78 \mathrm{O} 20=975.13$

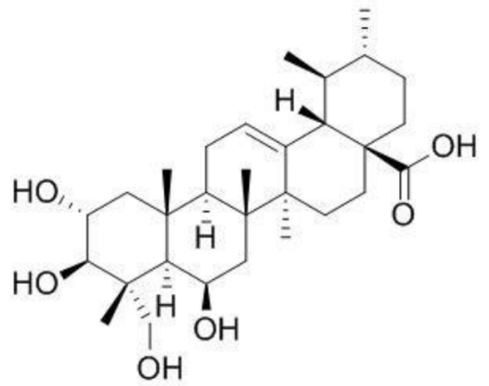

Madecassic acid

$\mathrm{C} 30 \mathrm{H} 48 \mathrm{O} 6=504.70$

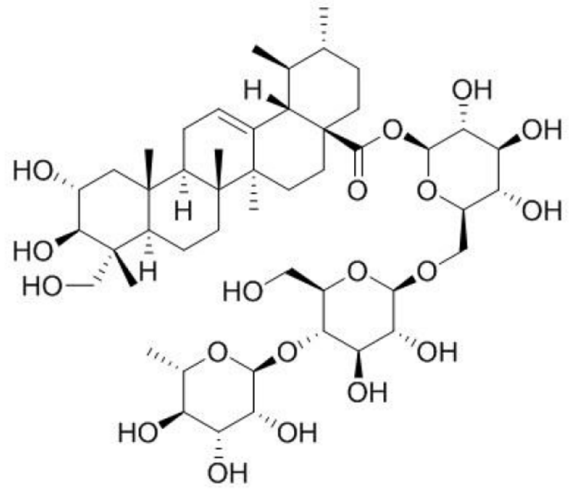

Asiaticoside

C48H78O19 $=959.12$

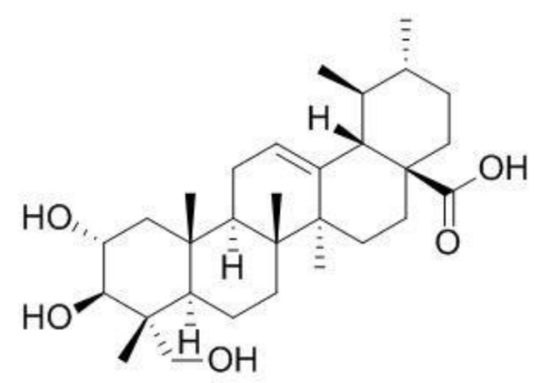

Asiatic acid

$\mathrm{C} 30 \mathrm{H} 48 \mathrm{O} 5=488.7$

FIGURE 1 | Molecular formulas of several main compounds of Centella asiatica.

weight of $975.1 \mathrm{~g} / \mathrm{mol}$. It is widely distributed in the heart, liver, spleen, lung, brain, stomach, skin, and kidney through oral dosing, reaching maximum levels within 5-15 min after oral administration (Leng et al., 2013; Anukunwithaya et al., 2017). Asiaticoside (pubchem CID: 52912190) has a molecular formula of $\mathrm{C} 48 \mathrm{H} 78 \mathrm{O} 19$ and a molecular weight of $959.1 \mathrm{~g} / \mathrm{mol}$. It also reaches maximum levels within 5-15 min after oral administration. Asiaticoside is extensively distributed in the brain, stomach, and skin within $1 \mathrm{~h}$ after dosing (Anukunwithaya et al., 2017). Madecassic acid (pubchem CID: 73412) has a molecular formula of $\mathrm{C} 30 \mathrm{H} 48 \mathrm{O} 6$ and a molecular weight of $504.7 \mathrm{~g} / \mathrm{mol}$. It is a pentacyclic triterpenoid in which ursane is substituted by a carboxy group at position 28 and hydroxy groups at positions 2 , 3,6 , and 23 (the 2alpha, 3beta, 6beta stereoisomer). A previous study confirmed that madecassic acid was found in the plasma, brain, heart, liver, kidney, colon, and bladder after oral administration (Yin et al., 2012). The molecular formula of asiatic acid (pubchem CID: 119034) is $\mathrm{C} 30 \mathrm{H} 48 \mathrm{O} 5$, and the degree of solubility in water is $5.98 \times 10^{-2} \mathrm{mg} / \mathrm{L}$ at $25^{\circ} \mathrm{C}$. Although asiatic acid is mainly absorbed in the jejunum (Yuan et al., 2015), it is also distributed in the plasma, brain, heart, liver, kidney, colon, and bladder (Yin et al., 2012). The results were consistent with the review by Ojha et al. They pointed out that for the physicochemical properties of asiatic acid, it is hardly soluble in water, but stable in saline. Its critical micelle concentration and surface tension are $15 \pm$ $2 \mathrm{M}$ and $64.1 \mathrm{mN} / \mathrm{m}$, respectively. Moreover, preclinical and clinical pharmacokinetic data demonstrated that asiatic acid could be distributed in many tissues by binding with albumin. Although the bioavailability of asiatic acid is poor, derivatives of asiatic acid showed multiple therapeutic values. Furthermore, chemical modification of the asiatic acid's backbone improved its bioavailability and biological activity (Table 1) (Lv et al., 2018; Nagoor et al., 2018). Asiatic acid and madecassic acid are biologically active ingredients of glycosides. Although in tissues and plasma their concentration is low, they can be detected in feces within $48 \mathrm{~h}$ after oral administration of $C$. asiatica extract. It 
TABLE 1 | Pharmacokinetic parameters of four triterpenes.

\begin{tabular}{|c|c|c|c|c|c|c|c|c|}
\hline Chemical & Treatment & Dose/Route & Species & $C_{\max }(\mu g / L)$ & $T_{\max }(h)$ & $A U C C_{(0-24)}(\mu \mathrm{g} \times \mathrm{h} / \mathrm{L})$ & Oral bioavailability (\%) & References \\
\hline \multirow[t]{4}{*}{ Madecassoside } & Single & 500 mg/p.o & human & $5.67 \pm 0.62$ & 1 & $30.12 \pm 7.12$ & Not mentioned & (Songvut et al., 2019) \\
\hline & Multiple & 500 mg/p.o & human & $5.23 \pm 1.84$ & 1 & $37.29 \pm 16.52$ & Not mentioned & \\
\hline & Single & $50 \mathrm{mg} / \mathrm{kg} / \mathrm{i} . \mathrm{v}$ & rat & NA & NA & $1436900 \pm 562001$ & NA & (Anukunwithaya et al., 2017) \\
\hline & Single & $50 \mathrm{mg} / \mathrm{kg} / \mathrm{p} .0$ & rat & $1654 \pm 884$ & $0.25 \pm 0.00$ & $2712 \pm 1883$ & 0.19 & \\
\hline \multirow[t]{4}{*}{ Asiaticoside } & Single & 500 mg/p.o & human & $1.50 \pm 0.18$ & 1 & $1.70 \pm 0.53$ & Not mentioned & (Songvut et al., 2019) \\
\hline & Multiple & 500 mg/p.o & human & $2.71 \pm 1.08$ & 2 & $11.40 \pm 9.67$ & Not mentioned & \\
\hline & Single & $50 \mathrm{mg} / \mathrm{kg} / \mathrm{i.v}$ & rat & NA & NA & $543530 \pm 156158$ & NA & (Anukunwithaya et al., 2017) \\
\hline & Single & $50 \mathrm{mg} / \mathrm{kg} / \mathrm{p} .0$ & rat & $318 \pm 192$ & $0.19 \pm 0.10$ & $796 \pm 910$ & 0.15 & \\
\hline \multirow[t]{2}{*}{ Madecassic acid } & Single & 500 mg/p.o & human & $52.14 \pm 18.67$ & 1.5 & $357.20 \pm 116.65$ & Not mentioned & (Songvut et al., 2019) \\
\hline & Multiple & 500 mg/p.o & human & $80.79 \pm 27.76$ & 1.5 & $681.05 \pm 413.17$ & Not mentioned & \\
\hline \multirow[t]{2}{*}{ Asiatic acid } & Single & 500 mg/p.o & human & $84.08 \pm 33.91$ & 1 & $724.75 \pm 259.98$ & Not mentioned & (Songvut et al., 2019) \\
\hline & Multiple & 500 mg/p.o & human & $116.62 \pm 32.26$ & 1 & $1202.29 \pm 293.37$ & Not mentioned & \\
\hline
\end{tabular}

p.o, per os; i.v, intravenous administration; $C_{\text {max }}$ maximal/peakplasma concentration; $T_{\text {max }}$, time to reach peak plasma concentration; AUC, area under the curve; NA, not applicable; Dose, ECa 233 doses.

suggests that triterpenoid glycosides are mainly metabolized in the intestine. (Anukunwithaya et al., 2017). In summary, madecassoside, asiaticoside, madecassic acid, and asiatic acid are widely distributed in the body and madecassoside, asiaticoside may exert their biological activity through converted into aglycone (madecassic acid, and asiatic acid).

C. asiatica is a traditional Chinese medicine with a wide range of functions. However, to date, the therapeutic effect of this traditional Chinese medicine on multiple diseases has not been systematically reviewed. Therefore, this study retrieved literature on $C$. asiatica and its main components and summarized their impacts on different diseases, so as to understand the broad pharmacological effects of C. asiatica comprehensively.

\section{Methodology}

The database PubMed was searched for literature on C. asiatica published between January 1, 2015, and October 19, 2019, using the following search terms: (Centella[MeSH Terms]) OR ( $((()((()(()(()(((($ Hydrocotyle[Title/Abstract] $))$ OR Hydrocotyles [Title/Abstract]) OR Centella asiatica[Title/Abstract]) OR Centella asiaticas[Title/Abstract]) OR asiatica, Centella[Title/Abstract]) OR Gotu kola[Title/Abstract]) OR Gotu kolas[Title/Abstract]) OR kola, Gotu[Title/Abstract]) OR Mandukaparni[Title/Abstract]) OR Mandukaparnus[Title/Abstract]) OR Hydrocotyle asiatica[Title/ Abstract]) OR Hydrocotyle asiaticas[Title/Abstract]) OR asiaticas, Hydrocotyle[Title/Abstract])) OR (Centella asiatica (L.) Urb.[Title/ Abstract])) OR (Centella asiatica var. asiatica[Title/Abstract])) OR (Centella asiatica var. crista Makino[Title/Abstract])) OR (acariçoba [Title/Abstract])) OR (artaniyae-hindi[Title/Abstract])) OR (asiatic pennywort[Title/Abstract])) OR (asiatic pennywort herb[Title/ Abstract])). The search did not exclude studies based on language or status of the publication.

\section{Inclusion Criteria}

The following types of studies were included: (a) experimental studies; (b) clinical trial; (c) not a case report or a review; and (d) medicine identified as $C$. asiatica or the $C$. asiatica extract.

\section{Exclusion Criteria}

The following types of studies were excluded: (a) full text not available; and (b) treatments combined with other ingredients.

\section{RESULTS}

A total of 276 studies were retrieved according to the screening criteria, of which 140 did not meet the inclusion criteria, 14 were excluded because they were reviews, and 13 were excluded for other reasons in full-text study eligibility assessment. Among the 109 studies included, 58 were in vivo experiments, 36 in vitro experiments, 11 in vivo and in vitro experiments, and 4 clinical trials (Figure 2). Several studies indicated that C. asiatica and its triterpenes were effective in many diseases. These diseases were summarized according to different body systems. The pathological mechanisms underlying these diseases were compared, and the mechanisms through which $C$. asiatica and its extracts affected these diseases were summarized. Based on these findings, a systematic review of the effect of C. asiatica on systemic diseases and the possible underlying mechanisms was performed.

\section{Effects on Neurological Diseases}

C. asiatica enhances the function of the nervous system. It dissolves in methanol, ethanol, and water. Relevant literature on the nervous system demonstrated that $C$. asiatica and its triterpenes could be used to relieve a variety of neurological diseases, but the most researched are improve Alzheimer's disease (AD) (Song et al., 2018) and Parkinson's disease (Nataraj et al., 2017b) (Table 2). The pathogenesis of AD and Parkinson's disease involve neuroinflammatory activities (Gelders et al., 2018), oxidative stress (Jiang et al., 2016), mitochondrial dysfunction (Morais and De Strooper, 2010), and dysfunction in brain-derived neurotrophic factor (Mohammadi et al., 2018). Therefore, this study focused on how C. asiatica and its triterpenes affected neurological diseases from the aforementioned four aspects.

First and foremost, the inflammatory cytokines produced by neuroinflammation are closely related to the occurrence of neurodegenerative lesions, which are manifested in $\mathrm{AD}$ by affecting the expression and metabolism of amyloid precursor protein (Alasmari et al., 2018). The main pathological change of $\mathrm{AD}$ is characterized by the accumulation of beta-amyloid $(\mathrm{A} \beta)$ containing neuritic plaques and neurofibrillary tangles (Yuan et al., 2020). Neuroinflammation is also crucial pathogenesis for 


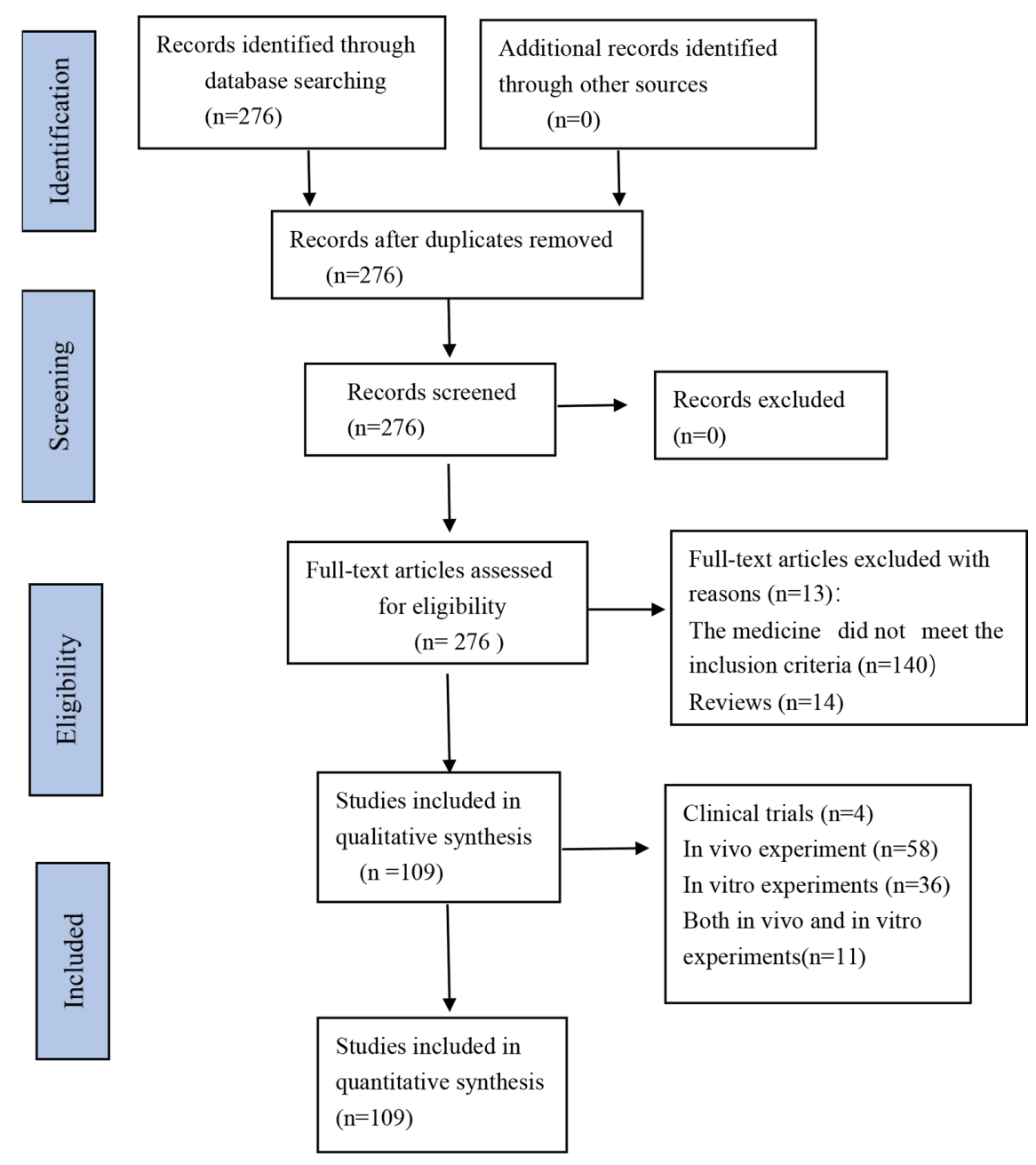

FIGURE 2 | Flow Diagram.

Parkinson's disease (Chen Z. et al., 2018). The chronic increase of pro-inflammatory mediators induces neurotoxic $A \beta$, plaque formation in $\mathrm{AD}$, and induces neurodegeneration in $\mathrm{PD}$. These pro-inflammatory mediators further aggravate neuroinflammation by recruiting immune cells to the brain. Neuroinflammation affect cells proliferation and maturation through pro-inflammatory cytokines, leading to synaptic dysfunction and neuronal death; thus, are responsible for effectuation of $\mathrm{AD}$ and $\mathrm{PD}$ (Kempuraj et al., 2017; Martinez-Cue and Rueda, 2020).

Second, oxidative stress refers to a state of imbalance between oxidative and antioxidant effects in the body; it is considered to be an important factor leading to aging. Increased production of reactive oxygen species (ROS) can directly affect neuronal synaptic activity and neurotransmission, leading to cognitive dysfunction. Under normal conditions, superoxide dismutase (SOD), glutathione peroxidase (GPX), and catalase can act as free radical scavengers, affecting the level of ROS. The activation of nuclear factor erythroid-2-related factor 2 (Nrf2) prevents oxidative stress (Tönnies and Trushina, 2017). Previous studies found that $C$. asiatica and its triterpenoids could effectively increase SOD and GPX activities, activate nuclear factor erythroid-2-related factor 2, improve the cognitive impairment of animals, and then alleviate the symptoms of related diseases (Gray et al., 2017a; Chintapanti et al., 2018; Welbat et al., 2018).

Third, mitochondria are the main place where cells carry out aerobic respiration. Mitochondrial dysfunction is closely related to the occurrence of $\mathrm{AD}$ and Parkinson's disease. The signaling pathway of cell death can be activated by mitochondrial ROS. Hence, restoring mitochondrial dysfunction can recover neuronal function in $\mathrm{AD}$ and Parkinson's disease (Onyango et al., 2017). The results showed that C. asiatica and its triterpenoids could reduce ROS production (Gray et al., 2017a; Nataraj et al., 2017a).

Last but not least, brain-derived neurotrophic factor is closely related to neuron maintenance, neuron survival, and neurotransmitter regulation. The concentration of this factor is reduced in the brain of patients with neurodegenerative diseases (Lima Giacobbo et al., 2019). C. asiatica extract, asiatic acid, and 
TABLE 2 | Effects on neurological diseases.

\begin{tabular}{|c|c|c|c|c|c|c|}
\hline Disease model & Type & $\begin{array}{l}\text { Solvent } \\
\text { composition } \\
\text { of extract }\end{array}$ & Animal/cell & $\begin{array}{l}\text { Signaling } \\
\text { pathway }\end{array}$ & Major findings & References \\
\hline- & $\begin{array}{l}\text { In vitro } \\
\text { and in } \\
\text { vivo }\end{array}$ & $\begin{array}{l}\text { Methanolic } \\
\text { extract of CA }\end{array}$ & Male Wistar rats & - & $\mathrm{MDA} \downarrow, \mathrm{GSH} \uparrow, \mathrm{SOD} \uparrow, \mathrm{AChE} \downarrow$ & $\begin{array}{l}\text { (Arora et al., } \\
\text { 2018) }\end{array}$ \\
\hline- & In vivo & $\begin{array}{l}\text { Ethanolic } \\
\text { extract of CA }\end{array}$ & Adult male Swiss mice & - & Antinociceptive, anti-inflammatory, and anxiolytic-like & $\begin{array}{l}\text { (Oliveira et al., } \\
\text { 2017) }\end{array}$ \\
\hline Sleep deprivation & In vivo & $\begin{array}{l}\text { Ethanolic } \\
\text { extract of CA }\end{array}$ & Male LACA mice & - & $\begin{array}{l}\text { Gross locomotor activity } \uparrow \text {, anxiety-like behavior } \downarrow \text {, } \\
\text { LPO } \downarrow, \text { GSH} \uparrow \text {, catalase enzyme } \uparrow, \text { SOD } \uparrow, T N F-\alpha \downarrow \text {, } \\
\text { AChE } \downarrow\end{array}$ & $\begin{array}{l}\text { (Chanana and } \\
\text { Kumar, 2016) }\end{array}$ \\
\hline- & $\begin{array}{l}\text { In vitro } \\
\text { and in } \\
\text { vivo }\end{array}$ & Asiatic acid & Male SD rats; hippocampal cell & - & $\begin{array}{l}\text { Spatial working memory } \uparrow, \mathrm{Ki}-67 \text { cells } \uparrow, \text { BrdU-positive } \\
\text { cells } \uparrow\end{array}$ & $\begin{array}{l}\text { (Welbat et al., } \\
\text { 2016) }\end{array}$ \\
\hline $\begin{array}{l}\text { Cognitive } \\
\text { impairments }\end{array}$ & $\begin{array}{l}\text { In vitro } \\
\text { and in } \\
\text { vivo }\end{array}$ & Asiatic acid & Male SD rats; hippocampal cell & - & $\begin{array}{l}\text { Ki-67-positive cells } \uparrow, \text { BrdU-positive cells } \uparrow \text {, and cell } \\
\text { survival in the dentate gyrus } \uparrow\end{array}$ & $\begin{array}{l}\text { (Chaisawang } \\
\text { et al., 2017) }\end{array}$ \\
\hline Hemiparkinsonism & In vivo & Asiaticoside & Male SD rats & MAPK & $\begin{array}{l}\mathrm{SOD} \uparrow, \mathrm{LPO} \uparrow, \mathrm{CAT} \uparrow, \mathrm{GSH} \uparrow \text {, dopamine } \uparrow \text {, glutamate } \uparrow, \\
\text { Syn1 } 1 \text {, Stx } 1 \mathrm{~A} \uparrow, \mathrm{PI} 3 \mathrm{~K} \uparrow, \mathrm{PDK} 1 \uparrow, \mathrm{PEBP} \downarrow, \mathrm{VMAT} 2 \uparrow, \mathrm{TH} \\
\uparrow, \mathrm{MAPK} \uparrow, \mathrm{BDNF} \uparrow, \mathrm{NGF} \uparrow\end{array}$ & $\begin{array}{l}\text { (Gopi and } \\
\text { Arambakkam } \\
\text { Janardhanam, } \\
\text { 2017) }\end{array}$ \\
\hline- & In vivo & $\begin{array}{l}\text { Centella } \\
\text { asiatica leaf } \\
\text { extract }\end{array}$ & Adult Wistar rats & - & $\begin{array}{l}\mathrm{AChE} \uparrow, \mathrm{SOD} \uparrow, \text { catalase } \uparrow, \mathrm{GPx} \uparrow, \text { Glutathione reductase } \\
\uparrow, \mathrm{GSH} \uparrow, \mathrm{MDA} \downarrow\end{array}$ & $\begin{array}{l}\text { (Chintapanti } \\
\text { et al., 2018) }\end{array}$ \\
\hline $\begin{array}{l}\text { Alzheimer's } \\
\text { disease }\end{array}$ & In vivo & $\begin{array}{l}\text { Water extract } \\
\text { of CA }\end{array}$ & Tg2576 mouse & - & Dendritic arborization $\uparrow$, dendritic spine density $\uparrow$, & $\begin{array}{l}\text { (Gray et al., } \\
\text { 2017a) }\end{array}$ \\
\hline $\begin{array}{l}\text { Alzheimer's } \\
\text { disease }\end{array}$ & In vivo & $\begin{array}{l}\text { Water extract } \\
\text { of CA }\end{array}$ & 5xFAD female mice & - & $\begin{array}{l}\text { Contextual memory } \uparrow, \mathrm{NRF} 2 \uparrow, \mathrm{NQO} 1 \uparrow, \mathrm{GCLC} \uparrow \\
\mathrm{HMOX} 1 \uparrow, \mathrm{PSD} 95 \uparrow, \mathrm{Mt}-\mathrm{ND} 1 \uparrow, \mathrm{Mt}-\mathrm{CYB} \uparrow, \mathrm{Mt}-\mathrm{CO} 1 \uparrow \\
\text { Mt-ATP6 } \uparrow, \text { mitochondrial respiration } \uparrow\end{array}$ & $\begin{array}{l}\text { (Gray et al., } \\
2018 a \text { ) }\end{array}$ \\
\hline $\begin{array}{l}\text { Alzheimer's } \\
\text { disease }\end{array}$ & in vitro & $\begin{array}{l}\text { Water extract } \\
\text { of CA }\end{array}$ & Tg2576 mice & - & $\begin{array}{l}\text { ROS } \downarrow \text {, NRF2 } \uparrow, \text { GCLC } \uparrow, \mathrm{HMOX} 1 \uparrow, \mathrm{NQO} 1 \uparrow, \mathrm{ATP} \uparrow, \mathrm{Mt}- \\
\mathrm{ND} 1 \uparrow, \mathrm{Mt}-\mathrm{ATP} 6 \uparrow, \mathrm{Mt}-\mathrm{CO} 1 \uparrow, \mathrm{Mt}-\mathrm{CYB} \uparrow \text {, oxygen } \\
\text { consumption rate } \uparrow\end{array}$ & $\begin{array}{l}\text { (Gray } \\
\text { et al., 2017b) }\end{array}$ \\
\hline- & in vivo & $\begin{array}{l}\text { Water extract } \\
\text { of CA }\end{array}$ & Male and female CB6F1 mice & - & $\begin{array}{l}\text { Location memory } \uparrow \text {, recognition memory } \uparrow \text {, learning and } \\
\text { executive function } \uparrow \text {, synaptic density } \uparrow, N R F 2 \uparrow, \text { porin } \uparrow\end{array}$ & $\begin{array}{l}\text { (Gray et al., } \\
\text { 2018a) }\end{array}$ \\
\hline- & in vivo & $\begin{array}{l}\text { Water extract } \\
\text { of CA }\end{array}$ & C57BL/6 mice & - & $\begin{array}{l}\mathrm{NRF} 2 \uparrow, \mathrm{NQO} 1 \uparrow, \mathrm{GCLC} \uparrow, \mathrm{HMOX} 1 \uparrow, \mathrm{Mt}-\mathrm{ND} 1 \uparrow, \mathrm{Mt}- \\
\mathrm{ATP} 6 \uparrow, \mathrm{Mt}-\mathrm{CO} 1 \uparrow, \mathrm{Mt}-\mathrm{CYB} \uparrow, \mathrm{PSD} 95 \uparrow\end{array}$ & (Gray et al., 2016) \\
\hline Chronic Stress & in vivo & $\begin{array}{l}\text { Ethanolic } \\
\text { extract of CA }\end{array}$ & Male SD rats & - & $\mathrm{TNF}-\alpha \downarrow, \mathrm{BDNF} \uparrow$ & $\begin{array}{l}\text { (Ar Rochmah } \\
\text { et al., 2019) }\end{array}$ \\
\hline $\begin{array}{l}\text { Alzheimer's } \\
\text { disease }\end{array}$ & in vivo & $\begin{array}{l}\text { Ethanolic } \\
\text { extract of CA }\end{array}$ & Male albino Wistar rats & $\begin{array}{l}\text { PP2A } \\
\text { GSK-3B }\end{array}$ & $\mathrm{PP} 2 \mathrm{~A} \uparrow, \mathrm{GSK}-3 \mathrm{~B} \downarrow, \mathrm{BCl}-2 \uparrow$ & $\begin{array}{l}\text { (Chiroma et al., } \\
\text { 2019a) }\end{array}$ \\
\hline- & in vivo & $\begin{array}{l}\text { Ethanolic } \\
\text { extract of CA }\end{array}$ & Male WKY rats & - & AMPAR GluA2 $\uparrow$, AMPAR GluA1 $\uparrow$, NMDAR GluN2B $\uparrow$ & $\begin{array}{l}\text { (Wong et al., } \\
\text { 2019) }\end{array}$ \\
\hline $\begin{array}{l}\text { Mild chronic } \\
\text { cerebral } \\
\text { hypoperfusion }\end{array}$ & in vivo & $\begin{array}{l}\text { Standardized } \\
\text { extract of CA }\end{array}$ & Male SD rats & - & dead neurons $\downarrow$, learning flexibility and memory $\uparrow$ & $\begin{array}{l}\text { (Thong-Asa et al., } \\
\text { 2018) }\end{array}$ \\
\hline- & in vivo & Asiatic acid & Male SD rats & - & Notch1 $1, \mathrm{Ki}-67 \uparrow, \mathrm{DCX} \uparrow$ & $\begin{array}{l}\text { (Sirichoat et al., } \\
\text { 2015) }\end{array}$ \\
\hline- & in vivo & $\begin{array}{l}\text { Standardized } \\
\text { extract of CA }\end{array}$ & Male Wistar rats & - & $\mathrm{NR} 2 \mathrm{~A} \uparrow, \mathrm{NR} 2 \mathrm{~B} \uparrow, \mathrm{BDNF} \uparrow, \mathrm{TrkB} \uparrow$ & $\begin{array}{l}\text { (Boondam et al., } \\
\text { 2019) }\end{array}$ \\
\hline- & in vivo & Asiatic acid & Male SD rats & - & 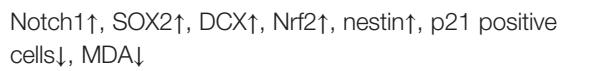 & $\begin{array}{l}\text { (Welbat et al., } \\
\text { 2018) }\end{array}$ \\
\hline $\begin{array}{l}\text { Alzheimer's } \\
\text { disease }\end{array}$ & in vivo & Asiatic acid & Male albino Wistar rats & $\mathrm{NF}-\kappa \mathrm{B}$ & $\begin{array}{l}\text { APP } \downarrow, A \beta 1-42 \downarrow, \beta-, \gamma-\text { secretases } \downarrow, \text { GFAP } \downarrow,\|L-1 \beta \downarrow,\|- \\
2,4,6 \downarrow, \text { TNF- } \alpha \downarrow, \text { iNOS } \downarrow, \text { COX- } 2 \downarrow\end{array}$ & $\begin{array}{l}\text { (Rather et al., } \\
\text { 2018a) }\end{array}$ \\
\hline $\begin{array}{l}\text { Parkinson's } \\
\text { disease }\end{array}$ & in vivo & Asiatic acid & Male C57Bᄂ/6 mice & $\begin{array}{l}\text { PI3K/Akt/ } \\
\text { mTOR }\end{array}$ & $\begin{array}{l}\mathrm{DAT} \uparrow, \mathrm{VMAT}-2 \uparrow, \mathrm{p}-\mathrm{JNK} \downarrow \downarrow, \mathrm{p}-\mathrm{P} 38 \downarrow, \mathrm{BDNF} \uparrow, \mathrm{GDNF} \uparrow \\
\mathrm{VEGF} \uparrow, \mathrm{TrkB} \uparrow, \mathrm{p}-\mathrm{PI} 3 \mathrm{~K} \uparrow, \mathrm{p}-\mathrm{Akt} \uparrow, \mathrm{p}-\mathrm{GSK} 3 \beta \uparrow, \mathrm{p}- \\
\mathrm{mTOR} \uparrow, \mathrm{p}-\mathrm{p} 70 \mathrm{~S} 6 \mathrm{~K} \uparrow\end{array}$ & $\begin{array}{l}\text { (Nataraj et al., } \\
\text { 2017b) }\end{array}$ \\
\hline $\begin{array}{l}\text { Alzheimer's } \\
\text { disease }\end{array}$ & in vivo & $\begin{array}{l}\text { CA standard } \\
\text { extract }\end{array}$ & Male albino Wistar rats & - & Alleviated the cognitive impairments & $\begin{array}{l}\text { (Chiroma et al., } \\
\text { 2019b) }\end{array}$ \\
\hline $\begin{array}{l}\text { Sleep restriction, } \\
\text { paradoxical sleep } \\
\text { deprivation }\end{array}$ & In vivo & $\begin{array}{l}\text { Aqueous } \\
\text { solutionso of } \\
\mathrm{Hb}\end{array}$ & Swiss nulliparous female mice & - & Learning $\uparrow$, memory $\uparrow, A C h E \downarrow$ & $\begin{array}{l}\text { (Barbosa et al., } \\
\text { 2019) }\end{array}$ \\
\hline- & In vivo & Asiaticoside-D & Worms & - & $\mathrm{MAO}-\mathrm{A} \downarrow, \mathrm{MAO}-\mathrm{B} \downarrow$ & $\begin{array}{l}\text { (Subaraja and } \\
\text { Vanisree, 2019) }\end{array}$ \\
\hline
\end{tabular}


TABLE 2 | Continued

\begin{tabular}{|c|c|c|c|c|c|c|}
\hline Disease model & Type & $\begin{array}{l}\text { Solvent } \\
\text { composition } \\
\text { of extract }\end{array}$ & Animal/cell & $\begin{array}{l}\text { Signaling } \\
\text { pathway }\end{array}$ & Major findings & References \\
\hline $\begin{array}{l}\text { Alzheimer's } \\
\text { disease }\end{array}$ & In vivo & Asiatic acid & Male albino Wistar rats & $\begin{array}{l}\text { Akt/GSK- } \\
3 \beta\end{array}$ & 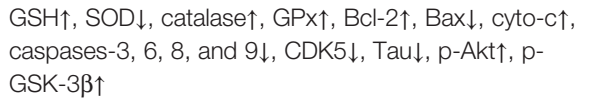 & $\begin{array}{l}\text { (Ahmad Rather } \\
\text { et al., 2019) }\end{array}$ \\
\hline- & In vivo & $\begin{array}{l}\text { Ethanolic } \\
\text { extract of CA }\end{array}$ & Albino male Wistar rats & - & AMPA GluA1 receptor $\uparrow$ & $\begin{array}{l}\text { (Binti Mohd Yusuf } \\
\text { Yeo et al., 2018) }\end{array}$ \\
\hline $\begin{array}{l}\text { Alzheimer's } \\
\text { disease }\end{array}$ & in vitro & Asiatic acid & $\begin{array}{l}\text { Human neuroblastoma SH-SY } \\
5 Y \text { cell }\end{array}$ & $\begin{array}{l}\text { Akt/ } \\
\text { GSK3 } \beta\end{array}$ & 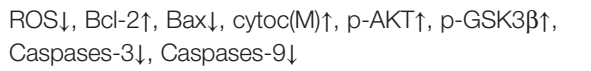 & $\begin{array}{l}\text { (Rather et al., } \\
\text { 2018b) }\end{array}$ \\
\hline- & in vitro & Asiatic acid & BV2 microglia cells & $\begin{array}{l}\text { Sirt1/NF- } \\
\kappa B\end{array}$ & 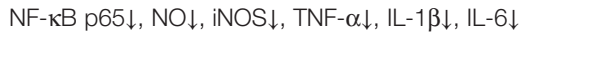 & (Qian et al., 2018) \\
\hline $\begin{array}{l}\text { Alzheimer's } \\
\text { disease }\end{array}$ & in vitro & Asiaticoside & $\begin{array}{l}\text { Human brain microvascular } \\
\text { endothelial cells }\end{array}$ & $\begin{array}{l}\text { TLR4/NF- } \\
\mathrm{kB}\end{array}$ & TNF- $\alpha \downarrow, \mid L-6 \downarrow$, TLR4 $\downarrow$, TRAF6 $\downarrow, p-p 65 \downarrow$ & $\begin{array}{l}\text { (Song et al., } \\
\text { 2018) }\end{array}$ \\
\hline $\begin{array}{l}\text { Alzheimer's } \\
\text { disease }\end{array}$ & in vitro & $\begin{array}{l}\text { Water extract } \\
\text { of } \mathrm{CA}\end{array}$ & $\begin{array}{l}\text { MC65 and the SH-SY5Y } \\
\text { neuroblastoma cell }\end{array}$ & - & 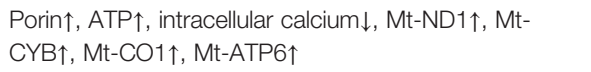 & (Gray et al., 2015) \\
\hline $\begin{array}{l}\text { Alzheimer's } \\
\text { disease }\end{array}$ & in vitro & $\begin{array}{l}\text { Ethanolic } \\
\text { extract of CA }\end{array}$ & $\begin{array}{l}\text { Rat PC12 pheochromocytoma } \\
\text { cells and human IMR32 } \\
\text { neuroblastoma Cells }\end{array}$ & - & SOD $\uparrow$, catalase $\uparrow, \mathrm{GR} \uparrow, \mathrm{GP} \times \uparrow, \mathrm{GSH} / \mathrm{GSSG} \uparrow$ & $\begin{array}{l}\text { (Chen et al., } \\
\text { 2016) }\end{array}$ \\
\hline- & in vitro & Madecassoside & BV2 microglia cells & $N F-\kappa B$ & $\mathrm{ROS} \downarrow$, iNOS $\downarrow, \mathrm{COX}-2 \downarrow, \mathrm{HO}-1 \downarrow, \mathrm{STAT} 1 \downarrow, \mathrm{NF}-\kappa \mathrm{B} \downarrow$ & $\begin{array}{l}\text { (Sasmita et al., } \\
\text { 2018) }\end{array}$ \\
\hline Cerebral ischemia & in vitro & Asiaticoside & Ischemia hypoxia cell & - & Lactate dehydrogenase $\downarrow$, Bcl-2 $2 \uparrow$, Bax $\downarrow$, caspase-3 $\downarrow$ & (Sun et al., 2015) \\
\hline $\begin{array}{l}\text { Parkinson's } \\
\text { disease }\end{array}$ & in vitro & Asiatic acid & $\begin{array}{l}\text { Human neuroblastoma (SH- } \\
\text { SY5Y) cell lines }\end{array}$ & - & $\begin{array}{l}\mathrm{ROS} \downarrow, \mathrm{MMP} \uparrow, \mathrm{Bcl}-2 \uparrow, \mathrm{Bax} \downarrow \text {, caspases-3, }-6,-8 \text {, and } \\
-9 \downarrow \text {, cyt c } \uparrow\end{array}$ & $\begin{array}{l}\text { (Nataraj et al., } \\
\text { 2017a) }\end{array}$ \\
\hline- & in vitro & $\begin{array}{l}\text { Water extract } \\
\text { of } \mathrm{CA}\end{array}$ & $\begin{array}{l}\text { Human mesenchymal stem } \\
\text { cell }\end{array}$ & - & Proliferation $\downarrow, \mathrm{S} 100 \beta \uparrow, \mathrm{p} 75 \mathrm{NGFR} \uparrow, \mathrm{MOG} \uparrow, \mathrm{GFAP} \uparrow$ & $\begin{array}{l}\text { (Omar et al., } \\
\text { 2019) }\end{array}$ \\
\hline
\end{tabular}

CA, Centella asiatica; MDA, malondialdehyde; GSH, glutathione; SOD, superoxide dismutase; AChE, acetylcholinesterase; LPO, lipid peroxidase; TNF- $\alpha$, tumour necrosis factor- $\alpha$; CAT, catalase; Syn1, synaptojanin 1; Stx1A, syntaxin 1A; PI3K, phosphoinositide 3-kinase; PDK1, phosphoinositide-dependent kinase-1; PEBP, phosphatidylethanolamine binding protein; VMAT2, vesicular monoamine transporter 2; TH, tyrosine hydroxylase; MAPK, mitogen-activated protein kinase; BDNF, brain-derived neurotrophic factor; NGF, nerve growth factor; GPX, glutathione peroxidase; NRF2, Nuclear factor(erythroid-derived2)-like2;NQO1, NAD(P)H dehydrogenase-quinone oxidoreductase 1; GCLC, glutamate-cysteine ligase, catalytic subunit; HMOX1, heme oxygenase 1; PSD95, post-synaptic density protein $95 ; M t-N D 1$, mitochondrially encoded NADH dehydrogenase 1;Mt-CYB, mitochondrially encoded cytochrome B;MtCO1, mitochondrially encoded cytochrome c oxidase 1; Mt-ATP6, mitochondrially encoded ATP synthase 6; ROS, reactive oxygen species; PP2A, protein phosphatase 2 ;GSK-3B, glycogen synthase kinase-3 beta; Bcl-2, B-cell lymphoma 2; AMPAR, $\alpha$-amino-3-hydroxy-5-methyl-4-isoxazolepropionic acid receptor; NMDAR, N-methyl-D-aspartate receptor; DCX, doublecortin; TrkB, tyrosine kinase B; SOX2, sex determining region Y-box 2; Nrf2, nuclear factor erythroid 2-related factor 2; APP, amyloid precursor protein; GFAP, anti-glial fibrillary acidic protein; IL, interleukins; iNOS, nitric oxide synthase; COX-2, cyclooxygenase- 2; DAT, Dopamine transporter; VMAT-2, Vesicular monoamine transporter-2; JNK, c-Jun N-terminal kinase-p53-Bax; GDNF, Glial cell line derived neurotophic factor; VEGF, Vascular endothelial growth factor; GSK3 $\beta$, Glycogen synthase kinase 3ß; MAO, monoamine oxidase; CDK5, cyclin-dependent kinase 5; NO, nitric oxide; MMP, metalloproteinase; TLR4,Toll-like receptor 4; GR, glutathione reductase; GSSG, glutathione disulphide; HO-1, heme oxygenase 1; STAT1, Signal transducer and activator of transcription 1; NGFR, nerve growth factor receptor; GFAP, glial fibrillary acidic protein; MBP, myelin binding protein. $\uparrow$, increase significantly; $\downarrow$, decrease significantly;-, not mentioned.

asiaticoside could effectively increase the content of brainderived neurotrophic factor (BDNF) (Gopi and Arambakkam Janardhanam, 2017; Nataraj et al., 2017b; Chintapanti et al., 2018; Boondam et al., 2019).

C. asiatica and its triterpenoids affect neurological diseases possibly through the mitogen-activated protein kinase (MAPK) signaling pathway, phosphotidylinositol 3 kinase/protein kinase B/ mammalian target of rapamycin (PI3K/Akt/mTOR)signaling pathway, and nuclear factor kappa-light-chain-enhancer of activated B cells (NF-kB) signaling pathway (Table 2). The MAPK signaling pathway is activated by a variety of extracellular stimuli, including growth factors, mitogens, hormones, cytokines, and different cellular stress factors (such as oxidative stress). Also, the p38 MAPK signaling pathway can modulate various events regarding $\mathrm{AD}$, such as tau phosphorylation, neurotoxicity, neuroinflammation, and synaptic dysfunction (Lee and Kim, 2017) The PI3K/Akt/mTOR pathway is a major intracellular signaling pathway that regulates the cell cycle. It is directly related to cellular quiescence, proliferation, and longevity. An in vivo study found that the inhibition of the PI3K/Akt/ mTOR signaling pathway led to a decrease in the expression of c-Jun
N-terminal kinase-p53-Bax 3(JNK3), thus protecting dopaminergic neurons and improving Parkinson's disease (Chen Y. et al., 2018). Moreover, ROS can mediate the PI3K/Akt/mTOR signaling pathway to exert related effects (Chen et al., 2017). NF- $\mathrm{\kappa B}$ is a protein complex that controls cytokine production, cell survival, and transcription of DNA. This signaling pathway is implicated in the process of many diseases of the brain (Saggu et al., 2016; Caviedes et al., 2017).

In conclusion, $C$. asiatica and its extracts had a positive effect on diseases of the nervous system. More importantly, C. asiatica and its extracts improved neurological diseases by reducing inflammatory factors, balancing oxidative stress, repairing abnormal expression of mitochondrial-related proteins, and improving the content of BDNF. In addition, they reduced related nerve cell apoptosis, increased synaptic density, and improved the survival rate of neural cells (Chaisawang et al., 2017; Gray et al., 2018a; Rather et al., 2018b).

\section{Effects on Endocrine Diseases}

C. asiatica extracts are promising in treating endocrine diseases, especially type 2 diabetes and obesity (Table 3 ). As for specific 
TABLE 3 | Effects on endocrine diseases.

\begin{tabular}{|c|c|c|c|c|c|c|}
\hline $\begin{array}{l}\text { Disease } \\
\text { model }\end{array}$ & Type & $\begin{array}{l}\text { Solvent } \\
\text { composition } \\
\text { of extract }\end{array}$ & Animal/cell & $\begin{array}{l}\text { Signaling } \\
\text { pathway }\end{array}$ & Major findings & References \\
\hline $\begin{array}{l}\text { Type } 2 \\
\text { diabetes } \\
\text { mellitus }\end{array}$ & $\begin{array}{l}\text { In } \\
\text { vivo }\end{array}$ & $\begin{array}{l}\text { Methanol } \\
\text { extract of CA }\end{array}$ & Male SD rats & - & $\begin{array}{l}\text { Blood glucose } \downarrow \text {, food and water intake } \downarrow \text {, ALT } \downarrow \text {, AST } \downarrow, \mathrm{PFK} \uparrow, \mathrm{GS} \uparrow, \mathrm{GP} \uparrow \text {, } \\
\text { glycogen content } \uparrow\end{array}$ & $\begin{array}{l}\text { (Oyenihi et al., } \\
\text { 2019) }\end{array}$ \\
\hline $\begin{array}{l}\text { Obese- } \\
\text { diabetic }\end{array}$ & $\begin{array}{l}\text { In } \\
\text { vivo }\end{array}$ & $\begin{array}{l}\text { Ethanol extract } \\
\text { of CA }\end{array}$ & Male SD rats & - & $\begin{array}{l}\text { Glucose } \downarrow \text {, cholesterol } \downarrow \text {, LDL } \downarrow \text {, choline } \uparrow \text {, succinate } \uparrow \text {, lactate } \uparrow \text {, glycerol } \\
\downarrow \text {, GPC } \downarrow \text {, leucine } \downarrow \text {, isoleucine } \downarrow\end{array}$ & $\begin{array}{l}\text { (Maulidiani } \\
\text { et al., 2016) }\end{array}$ \\
\hline Obesity & $\begin{array}{l}\text { In } \\
\text { vivo }\end{array}$ & Asiatic acid & Male SD rats & - & $\begin{array}{l}\text { Body weight } \downarrow \text {, plasma glucose } \downarrow \text {, insulin resistance } \downarrow \text {, leptin } \downarrow \text {, adiponectin } \\
\downarrow \text {, amylase } \downarrow \text {, pancreatic lipase } \downarrow \text {, SOD } \uparrow \text {, CAT } \uparrow, \text { GPX } \uparrow, \text { GSH } \uparrow, \text { CPT } 1 \uparrow \text {, } \\
\text { UCP } 2 \uparrow, \text { ACC } 1 \downarrow\end{array}$ & $\begin{array}{l}\text { (Rameshreddy } \\
\text { et al., 2018) }\end{array}$ \\
\hline $\begin{array}{l}\text { Type } 2 \\
\text { diabetes } \\
\text { mellitus }\end{array}$ & $\begin{array}{l}\text { In } \\
\text { vivo }\end{array}$ & $\begin{array}{l}\text { Methanol } \\
\text { extract of CA }\end{array}$ & Male SD rats & - & MDA $\downarrow$, GSH $\uparrow$, GST $\uparrow$, GPX $\uparrow, ~ I L-1 \beta \downarrow, I L-4 \downarrow$, MCP- $1 \downarrow$, TNF- $\alpha \downarrow, T G \downarrow$ & $\begin{array}{l}\text { (Oyenihi et al., } \\
\text { 2017) }\end{array}$ \\
\hline $\begin{array}{l}\text { Type } 2 \\
\text { diabetes } \\
\text { mellitus }\end{array}$ & $\begin{array}{l}\text { In } \\
\text { vivo }\end{array}$ & $\begin{array}{l}\text { Methanol } \\
\text { extract of CA }\end{array}$ & Male SD rats & - & Blood glucose $\downarrow, \mathrm{GSH} \uparrow, \mathrm{GST} \uparrow, \mathrm{GPX} \uparrow, \mathrm{MDA} \downarrow, \mathrm{TNF}-\alpha \downarrow, \mathrm{IFN}-\gamma \downarrow, \mathrm{IL}-10 \uparrow$ & $\begin{array}{l}\text { (Masola et al., } \\
\text { 2018) }\end{array}$ \\
\hline Hyperlipidemic & $\begin{array}{l}\text { In } \\
\text { vivo }\end{array}$ & $\begin{array}{l}\text { Water extract } \\
\text { of CA }\end{array}$ & $\begin{array}{l}\text { Male Wistar albino } \\
\text { rats }\end{array}$ & - & Body weight $\downarrow, T C \downarrow, T G \downarrow$, LDL-C $\downarrow, \mathrm{HDL}-\mathrm{C} \uparrow, \mathrm{SOD} \uparrow, \mathrm{GSH} \uparrow$ & $\begin{array}{l}\text { (Kumari et al., } \\
\text { 2016) }\end{array}$ \\
\hline Osteoporosis & $\begin{array}{l}\text { In } \\
\text { vitro } \\
+ \text { in } \\
\text { vivo }\end{array}$ & Madecassoside & $\begin{array}{l}\text { BMMs, estrogen } \\
\text { deficiency-induced } \\
\text { osteoporosis } \\
\text { mouse model }\end{array}$ & $\begin{array}{l}\text { NF-кB, } \\
\text { MAPK }\end{array}$ & $\begin{array}{l}\text { NFATc } 1 \downarrow \text {, C-Fos } \downarrow \text {, Acp5 } \downarrow \text {, CTSK } \downarrow \text {,VATPase- } d 2 \downarrow \text {, integrin } \beta 3 \downarrow \text {, calcium } \\
\text { oscillations } \downarrow \text {, trabecular spacing } \downarrow \text {, osteoclast surface/bone surface (Oc.S/ } \\
\text { BS) } \downarrow \text {, osteoclast number/bone surface (N.Oc/BS) } \downarrow \text {, bone volume/total } \\
\text { volume (BV/TV) } \uparrow, T b . N \uparrow\end{array}$ & $\begin{array}{l}\text { (Wang et al., } \\
\text { 2019) }\end{array}$ \\
\hline $\begin{array}{l}\text { Gestational } \\
\text { diabetic }\end{array}$ & $\begin{array}{l}\text { in } \\
\text { vitro }\end{array}$ & $\begin{array}{l}\text { Centella } \\
\text { asiatica }\end{array}$ & HUVECs & - & $\begin{array}{l}\text { VCAM- } 1 \downarrow \text {, ICAM- } 1 \downarrow \text {, monocyte adhesion } \downarrow \text {, p44/42 MAPK } \downarrow \text {, NF-kB p65 } \\
\downarrow\end{array}$ & $\begin{array}{l}\text { (Di Tomo } \\
\text { et al., 2015) }\end{array}$ \\
\hline
\end{tabular}

$A L T$, alanine transaminase; AST, aspartate transaminase; PFK, phosphofructokinase; GS, glycogen synthase; GP, glycogen phosphorylase; LDL, low-density lipoprotein; GPC, glycerophosphorylcholine; CPT-1, palmitoyltransferase-1; UCP 2, uncoupling protein-2; ACC, carboxylase; TG, triglycerides; MCP-1, monocyte chemoattractant protein-1; IFN- $\gamma$, interferon- $\gamma$, TC, total cholesterol; HDL-C, high density lipoprotein cholesterol; NFATC1, nuclear factor of activated T cells, cytoplasmic 1; CTSK, cathepsinK; VCAM-1, vascular cell adhesion molecule-1; ICAM-1, intercellular adhesion molecule-1; NF-kB p65, Nuclear Factor kappa-light-chain-enhancer of activated B cells.

compounds, asiatic acid was effective in obesity (Rameshreddy et al., 2018) and madecassoside might be a potential candidate for treating osteolytic bone diseases (Wang et al., 2019).

Type 2 diabetes mellitus (T2DM) is a form of diabetes characterized by high blood glucose, insulin resistance, and a weaker insulin-stimulated response in the presence of high blood glucose level (Zheng et al., 2018). Oxidative stress is mainly caused by lipid peroxidation and has been considered as the main indicator of the pathogenesis and development of T2DM. Oxidative stress causes microvascular and macrovascular complications (Rehman and Akash, 2017). In addition, the inflammation response may cause the occurrence of T2DM by inducing insulin resistance. The inflammation response is exacerbated in the presence of hyperglycemia and can, in turn, worsen hyperglycemia. Hence, targeting the inflammation pathway may be a potential strategy to prevent and control diabetes (Lontchi-Yimagou et al., 2013). In 2015, the World Health Organization defined the body mass index more than 30 $\mathrm{kg} / \mathrm{m}^{2}$ as obesity and $25-30 \mathrm{~kg} / \mathrm{m}^{2}$ as overweight (World Health Organisation, 2013). Obesity is a risk factor for many diseases, including cardiovascular disease, musculoskeletal muscle disease, and even cancer (Kolb et al., 2016; Ortega et al., 2016; Collins et al., 2018). Furthermore, obesity causes chronic inflammation of the body and inflammation involving multiple organs (e.g., liver, heart, skeletal muscle, and brain) (Saltiel and Olefsky, 2017). Osteoporosis is a bone metabolism disease, manifesting itself in the form of bone loss and structure degradation. Main targets are the middle-aged and elderly people over the age of 50 .
The occurrence of osteoporosis can be linked to other endocrine morbidities, like diabetes, obesity, thyroid hormone disease (Dolan et al., 2017; Tanaka et al., 2018; Delitala et al., 2020; Zou et al., 2020).

Based on the aforementioned pathological mechanisms, the potential mechanism of action of $C$. asiatica and its triterpenes on the diseases involving the endocrine system was elaborated from two aspects: reduced oxidative stress and exerted antiinflammatory effect. First, the $C$. asiatica extract seemed to improve the oxidative stress. Both the diabetic animal model and the obesity animal model demonstrated that the $C$. asiatica extract increased the GSH, CAT, and SOD activities, thereby improving the enzyme antioxidant system (Kumari et al., 2016; Masola et al., 2018; Rameshreddy et al., 2018). Second, the results of animal experiments showed that the $C$. asiatica extract could effectively decrease related inflammation factors (TNF- $\alpha$, IL-1 $\beta$, and IL-4). At the same time, it also reduced blood glucose and blood lipid levels (Oyenihi et al., 2017; Masola et al., 2018). Besides, the results showed that the extracts of $C$. asiatica lowered food and water intake and body weight, which suggested that $C$. asiatica extract may affect obesity by influencing the feeding center controlled by central nervous system (Halpern et al., 2008; Blanco et al., 2011). Moreover, the potential of asiatic acid as an anti-obesity agent can be proved from the facts that it suppresses weight gain, and enhance the sensitivity of leptin and insulin. At the molecular level, asiatic acid can increase the level of enzymatic antioxidants (CAT, GPx and SOD), reverse the expression of CPT-1 and UCP-2 that are 
suppressed by high-fat diet. Therefore, it can be deduced that asiatic acid can repair oxidative stress damage caused by obesity, and can also suppress weight gain by promoting fatty acid oxidation (Rameshreddy et al., 2018). The results of madecassoside intervention in a mouse model of osteoporosis, caused by estrogen deficiency and bone marrow monocytes showed that it can inhibit the expression of related genes by affecting the NF$\kappa \mathrm{B}$ and MAPK signaling pathways (NFATc1, c-Fos, Acp5, CTSK, VATPase-d2), inhibits the generation of osteoclasts, weaken the absorption activity of osteoclasts. It can be inferred that madecassoside can be a potential candidate for the treatment of osteoporosis (Wang et al., 2019).

In summary, available evidence showed that the $C$. asiatica extract and asiatic acid could (1) lower blood glucose levels, (2) improve insulin resistance, (3) inhibit weight gain (4) ameliorate inflammation, and (5) improve oxidative stress. Besides, madecassoside could improve osteoporosis by weakening the absorption of osteoclasts and reducing osteoclast formation. These results show that the prospects of $C$. asiatica extract and related components (asiatic acid, madecassoside) for the treatment of endocrine diseases such as diabetes, obesity and osteoporosis are excellent.

\section{Effects on Skin Diseases}

The C. asiatica extract and its triterpenoids had certain therapeutic and relieving effects on acne, baldness, vitiligo, atopic dermatitis, and wounds (Sawatdee et al., 2016; Choi et al., 2017; Ling et al., 2017; Ju Ho et al., 2018; Shen et al., 2019) (Table 4).

Acne is one of the most common skin disorders. Studies have pointed out that the activation of vascular endothelial cells and the involvement of inflammation responses are essential for the early stages of the development of acne lesions (Kircik, 2016). Vitiligo is an acquired depigmenting disorder of the skin, and one of the most common skin diseases. Some studies suggested that oxidative stress may be the initial cause of this disease. The main targets of ROS are mitochondria, causing structural and functional changes (Glassman, 2011). Atopic dermatitis, also known as atopic eczema, is a chronic relapsing inflammatory skin condition (Avena-Woods, 2017). This disease occurs due to skin barrier dysfunction, alterations in cell-mediated immune responses, and Immunoglobulin $\mathrm{E}(\mathrm{IgE})$-mediated hypersensitivity (David Boothe et al., 2017). Skin is the largest organ of the human body playing a vital role in maintaining the body's physiological homeostasis. The appearance of wounds can

TABLE 4 | Effects on skin diseases.

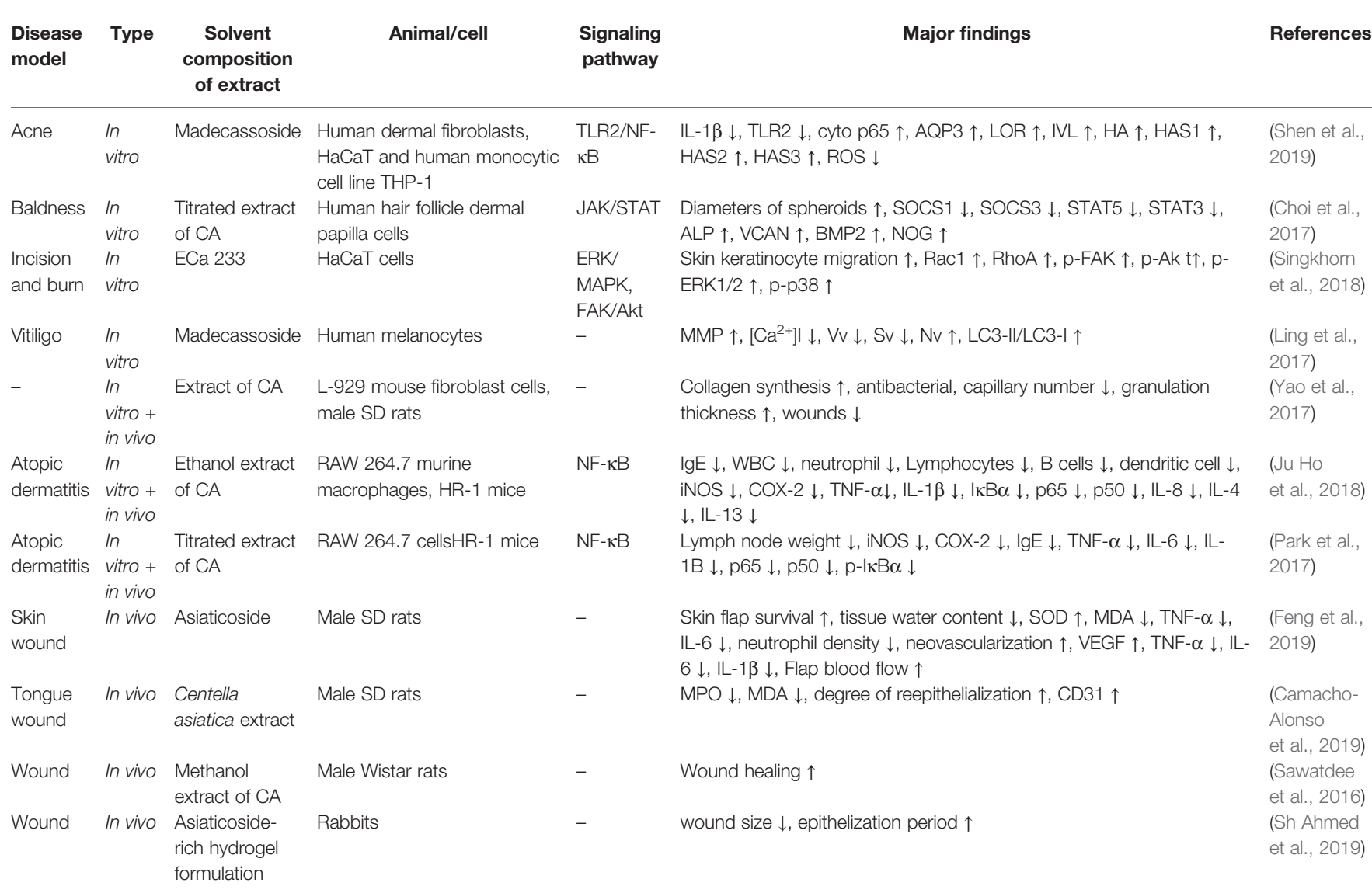

TLR2, toll-like receptor-2; AQP3, aquaporin-3; LOR, loricrin; IVL, involucrin; HA, hyaluronan; HAS, HA synthases; ALP, alkaline phosphatase; VCAN, versican; BMP2, bone morphogenetic protein 2; NOG, noggin; Rac1, Ras-related C3 botulinum toxin substrate 1; RhoA, Ras homolog gene family, member A; FAK, focal adhesion kinase; Akt, protein kinase B; ERK, extracellular signal-regulated kinases; VV, volume density; Sv, surface density; Nv, numeral density; IgE, immunoglobulin E; WBC, white blood cell; MPO, myeloperoxidase. 
lead to an imbalance in physiological homeostasis. The stages of wound healing comprise inflammation, proliferation, epithelialization, angiogenesis, remodeling, and scarring (Sorg et al., 2017).

According to the summary report by 1998 committee for veterinary medicinal products, the transdermal absorption of the active ingredients in C. asiatica in rats showed that madecassic acid can quickly penetrate the skin barrier, but the dose measured at the drug application point on the skin after $24 \mathrm{~h}$ was only $0.06 \%$ concentrated as compared to the original dose. The results of asiatic acid were similar to madecassic acid. The high concentration of asiaticoside administered transdermally did not cause any systemic toxicity, but it could cause excessive keratinization of the skin at the application site. Some reports also suggested allergic dermatitis over using C. asiatica externally, but none of them reports the exact dose. C. asiatica and its triterpenoids are made into different formulations to explore the treatment options for skin diseases, and it has been established that they have a potential role in wound healing and skin inflammation.

First, for wound healing, the present study found that $C$. asiatica and its triterpenoids had a direct wound-healing function. C. asiatica extracted with methanol contains $0.12 \%$ asiatic acid, $0.54 \%$ madecassic acid, $0.25 \%$ asiaticoside and $1.02 \%$ madecassoside, and was made into a spray with hydroxypropyl$\beta$-cyclodextrin (HP- $\beta$-CD), Eudragit E100, glycerin, PEG 400, etc., and the spray of triterpenes content are close to $100 \%$ compared with $C$. asiatica extracted, of course, The wound was healed completely without any skin irritation (Sawatdee et al., 2016). Compared with ordinary gauze, the electrospun gelatin membranes containing $C$. asiatica can promote the wound repair process by affecting the proliferation of fibroblasts and collagen synthesis, and are antibacterial as well (Yao et al., 2017). The asiaticoside-rich hydrogel formulation exhibited $40 \%$ fast wound healing without any skin irritation as compared to untreated group. Thick epithelial layer and keratin formation can be found, while granulation tissue, fibroblasts and collagen were formed moderately (Sh Ahmed et al., 2019). Cells studies have found that C. asiatica standard extract (ECa 233) can affect the formation of filopodia and promote wound healing by activating the FAK, Akt and MAPK signaling pathways (Singkhorn et al., 2018). In above studies, though the vehicles were different, but animal and cell experiments have found that $C$. asiatica and its triterpenoids improved the degree of re-epithelialization, increased the collagen synthesis, reduced the inflammation around wounds and cause no obvious skin irritation.

Second, for the treatment of atopic dermatitis, C. asiatica significantly reduced the inflammation response (TNF- $\alpha \downarrow$, IL$1 \beta \downarrow$, IL- $8 \downarrow$, IL- $4 \downarrow$, and IL-13 $\downarrow$ ), and also the local immune response (IgE $\downarrow$ ). Whether titrated extract of $C$. asiatica (TECA) or ethanol extract of $C$. asiatica, both seems to inhibit hyperkeratosis, mast cell and inflammatory cell infiltration. Both of them can inhibit the expression of iNOS and COX-2 and $\mathrm{NF}-\kappa \mathrm{B}$ activity, it confirms that $C$. asiatica extract may be a promising therapeutic TCM for the treatment of atopic dermatitis (Park et al., 2017; Ju Ho et al., 2018). The effect of madecassoside in the treatment of dermatitis is reflected in reducing the pro-inflammatory cytokines (IL-1 $\beta$, TLR2), moreover, it can promote the secretion of AQP3, LOR, IVL in $\mathrm{HaCaT}$ keratinocytes and the secretion of HA in human skin fibroblasts, thus can significantly enhance skin hydration (Shen et al., 2019).

Third, madecassoside, a specific component of C. asiatica, had a certain improvement effect on vitiligo, and the possible mechanism of action was to reduce the oxidative stress response and weaken the damage to mitochondria by oxidative stress [matrix metalloproteinase (MMP) $\uparrow$ and $\left.\left[\mathrm{Ca}^{2+}\right] \mathrm{i} \downarrow\right]$. In addition, it was found that the LC3-II/LC3-I ratio of melanocytes treated with madecassoside increased significantly, suggesting that it enhances the autophagy activation of the cells, thereby protecting skin cells from physiological and pathological aging damage. (Ling et al., 2017). Lastly, C. asiatica also demonstrated a positive activation effect on dermal papilla, improved the viability of dermal papilla cells and increased the expression of characteristic genes related to hair growth in the cells, thus providing good application prospects for baldness (Choi et al., 2017).

Although C. asiatica and its triterpenoids have low transdermal absorption rate, current animal experiments and cell experiments have found that they can effectively promote wound healing, reduce skin inflammatory diseases, and seem to have a certain effect on vitiligo and baldness. The mechanism of action of $C$. asiatica and its ingredients in the treatment of skin diseases is mainly anti-inflammation, anti-oxidation, and weakening of the damage to mitochondria by oxidative stress, which was consistent with the pathogenesis of these diseases.

\section{Effects on Cardiovascular Diseases}

C. asiatica has a positive effect on cardiovascular diseases. The main components that affect the cardiovascular system are asiaticoside and asiatic acid. Hypertension and atherosclerosis are the mostly studied diseases in involved articles (Table 5).

Hypoxic pulmonary hypertension can cause pulmonary arterial changes, including pulmonary arterial stiffness and narrowing. Ventricular changes caused by right ventricular hypertrophy and right ventricular fibrosis affect ventricular function (Wang and Chesler, 2013). Renovascular hypertension is one of the common causes of secondary hypertension. About $90 \%$ of cases are due to atherosclerotic renal artery stenosis and often accompanied by severe occlusive diseases of other blood vessels, accounting for poor prognosis (Matuszkiewicz-Rowińska and Wieliczko, 2015). The Ang II/AT1R signaling pathway can regulate a series of intracellular pathways to improve cardiac insufficiency and myocardial remodeling, which is closely associated with the occurrence and development of renal hypertension (Liu et al., 2017). The transverse aortic constriction contributes to the occurrence of cardiac hypertrophy and failure. The common pathological changes are systolic dysfunction and cardiac fibrosis of the heart. Pressure overload triggers the expression of inflammation genes. Inhibiting early inflammation reactions can reduce cardiac remodeling and improve heart function (Suetomi et al., 2018; Richards et al., 2019). Fibrosis is a pivotal player in the development and progression of heart 
TABLE 5 | Effects on cardiovascular diseases.

\begin{tabular}{|c|c|c|c|c|c|c|}
\hline $\begin{array}{l}\text { Disease } \\
\text { model }\end{array}$ & Type & $\begin{array}{l}\text { Solvent } \\
\text { composition } \\
\text { of extract }\end{array}$ & Animal/cell & $\begin{array}{l}\text { Signal } \\
\text { pathway }\end{array}$ & Major findings & References \\
\hline $\begin{array}{l}\text { Pulmonary } \\
\text { hypertension }\end{array}$ & $\begin{array}{l}\text { In } \\
\text { vivo } \\
+ \text { in } \\
\text { vitro }\end{array}$ & Asiaticoside & $\begin{array}{l}\text { Male SD rats, } \\
\text { rats' PASMCs }\end{array}$ & $\begin{array}{l}\text { TGF- } \beta 1 / \\
\text { Smad }\end{array}$ & $\begin{array}{l}\text { Mean pulmonary artery pressure } \downarrow \text {, right ventricular hypertrophy } \downarrow \text {, vessel } \\
\text { thickness } \downarrow \text {, media wall thickness } \downarrow \text {, TGF- } \beta 1 \downarrow \text {, TGF- } \beta R \| \downarrow \text {, p-Smad2/3 } \downarrow\end{array}$ & $\begin{array}{l}\text { (Wang et al., } \\
\text { 2015) }\end{array}$ \\
\hline $\begin{array}{l}\text { Renovascular } \\
\text { hypertension }\end{array}$ & $\begin{array}{l}\text { In } \\
\text { vivo }\end{array}$ & Asiatic acid & Male SD rats & $\begin{array}{l}\text { Ang II/AT } \\
{ }_{1} \mathrm{R} / \\
\text { NADPH } \\
\text { oxidase/ } \\
\text { NF- } \mathrm{kB}\end{array}$ & $\mathrm{SP} \downarrow, \mathrm{DP} \downarrow, \mathrm{MAP} \downarrow, \mathrm{HBF} \uparrow, \mathrm{HVR} \uparrow, \mathrm{Ang} \| \downarrow, \mathrm{AT} 1 \mathrm{R} \downarrow, \mathrm{AT} 2 \mathrm{R} \uparrow, \mathrm{O}_{2}^{-} \downarrow, \mathrm{MDA} \downarrow, \mathrm{TNF}-\alpha \downarrow$ & $\begin{array}{l}\text { (Maneesai } \\
\text { et al., 2017) }\end{array}$ \\
\hline $\begin{array}{l}\text { Transverse } \\
\text { aortic } \\
\text { constriction }\end{array}$ & $\begin{array}{l}\text { In } \\
\text { vivo }\end{array}$ & Asiatic acid & $\begin{array}{l}\text { Male C57BL/6 } \\
\text { mice }\end{array}$ & $\begin{array}{l}\text { TGF- } \beta 1 / \\
\text { Smad2/3 }\end{array}$ & $\begin{array}{l}\text { Ventricular wall thickness } \downarrow \text {, left ventricular posterior wall diastolic Dimensions } \downarrow \text {, } \\
\text { LVEDD } \downarrow \text {, FS } \uparrow \text {, cardiac output } \uparrow \text {, Bax/Bcl-2 } 2 \text {,caspase- } 9 \downarrow \text {, caspase-3 } \downarrow \text {, } \\
\text { cytochrome c } \downarrow \text {, TGF- } \beta 1 \downarrow \text {, } \alpha \text {-SMA } \downarrow \text {, collagen I } \downarrow \text {, TNF- } \downarrow \downarrow \text {, IL-6 } \downarrow \text {, NF-kB } \downarrow \text {, } \\
\text { JNK } \downarrow \text {, p-mad2/3/Smad } 2 / 3 \downarrow \text {, Smad7 } \uparrow\end{array}$ & $\begin{array}{l}\text { (Si et al., } \\
2015)\end{array}$ \\
\hline $\begin{array}{l}\text { Myocardial } \\
\text { ischemia/ } \\
\text { reperfusion } \\
(\mathrm{Ml} / \mathrm{R}) \text { injury }\end{array}$ & $\begin{array}{l}\text { In } \\
\text { vivo }\end{array}$ & Asiatic acid & Male SD rats & $\begin{array}{l}\text { Akt/GSK- } \\
3 \beta\end{array}$ & $\begin{array}{l}\text { LVEDV } \downarrow, \text { LVESV } \downarrow, \text { HR } \uparrow, \text { LV dp/dtmax } \uparrow, \text { LV dp/dtmin } \uparrow \text {, myocardial infarction } \\
\text { size } \downarrow, \text { LDH } \downarrow, \text { CK } \downarrow, p \text {-Akt } \uparrow, p \text {-GSK-3 } \uparrow \text {, plasma glucose } \downarrow \text {, plasma lactate } \downarrow\end{array}$ & $\begin{array}{l}\text { (Dai et al., } \\
\text { 2018) }\end{array}$ \\
\hline- & $\begin{array}{l}\text { In } \\
\text { vitro }\end{array}$ & Asiaticoside & $\begin{array}{l}\text { Human umbilical } \\
\text { vein endothelial } \\
\text { cells (HUVECs/ } \\
7 \text { th passage) }\end{array}$ & - & $\begin{array}{l}\text { Endothelial permeability } \downarrow \text {, ATP } \downarrow \text {, NO } \downarrow, \mathrm{H}_{2} \mathrm{O}_{2} \downarrow \text {, IL-18 } \downarrow \text {, sICAM- } 1 \downarrow \text {, sVCAM- } 1 \\
\downarrow \text {, E-selectin } \downarrow\end{array}$ & $\begin{array}{l}\text { (Jing et al., } \\
\text { 2018) }\end{array}$ \\
\hline $\begin{array}{l}\text { Pulmonary } \\
\text { hypertension }\end{array}$ & $\begin{array}{l}\text { In } \\
\text { vivo } \\
+\ln \\
\text { vitro }\end{array}$ & Asiaticoside & $\begin{array}{l}\text { Male SD rats; } \\
\text { HPAECs }\end{array}$ & $\begin{array}{l}\text { PI3K/Akt/ } \\
\text { eNOS }\end{array}$ & $\begin{array}{l}\text { Mean pulmonary artery pressure } \downarrow \text {, medial wall thickness } \downarrow \text {, Right ventricular } \\
\text { hypertrophy } \downarrow \text {, pulmonary arteriole wall thickening } \downarrow \text {, inflammatory cell infiltration } \\
\downarrow \text {, NO } \uparrow \text {, cGMP } \uparrow, \text { p-Akt } \uparrow, \text { p-eNOS } \uparrow \text {, caspase- } 3 \downarrow\end{array}$ & $\begin{array}{l}\text { (Wang } X . \\
\text { et al., 2018) }\end{array}$ \\
\hline Atherosclerosis & $\begin{array}{l}\text { In } \\
\text { vitro }\end{array}$ & Asiatic acid & $\begin{array}{l}\text { Human aortic } \\
\text { endothelial cells } \\
\text { (HAECs). }\end{array}$ & - & $\begin{array}{l}\text { F-actin rearrangement } \downarrow \text {, stabilize the F-actin filaments, MLC dephosphorylation } \\
\downarrow \text {, stabilize peripheral diphospho-MLC, VE-cadherin } \uparrow \text {, inhibit redistribution of } \\
\text { occludin and ZO- } 1\end{array}$ & $\begin{array}{l}\text { (Fong et al., } \\
\text { 2019) }\end{array}$ \\
\hline Atherogenic & $\begin{array}{l}\text { In } \\
\text { vitro }\end{array}$ & Asiaticoside & $\begin{array}{l}\text { Human aortic } \\
\text { endothelial cells }\end{array}$ & & Vascular permeability $\downarrow$ & $\begin{array}{l}\text { (Fong et al., } \\
\text { 2015) }\end{array}$ \\
\hline $\begin{array}{l}\text { Myocardial } \\
\text { ischemic/ } \\
\text { reperfusion } \\
\text { injury }\end{array}$ & $\begin{array}{l}\text { In } \\
\text { vitro }\end{array}$ & Asiatic Acid & $\begin{array}{l}\text { Rat H9c2 } \\
\text { Cardiomyocytes }\end{array}$ & $\begin{array}{l}\text { Akt/GSK- } \\
3 \beta / H I F-1 \alpha\end{array}$ & $\begin{array}{l}\text { Apoptotic cells } \downarrow \text {, caspase- } 9 \downarrow \text {, caspase-3 } \downarrow \text {, Bax/Bcl- } 2 \downarrow \text {, MMP } \uparrow, \mathrm{Ca}^{2+} \downarrow, \text { ROS } \\
\downarrow, \mathrm{p}-\mathrm{AKT} \uparrow, \mathrm{p}-\mathrm{GSK}-3 \beta \uparrow, \mathrm{HIF}-1 \alpha \uparrow\end{array}$ & $\begin{array}{l}\text { (Huang } \\
\text { et al., 2016) }\end{array}$ \\
\hline Atherogenesis & $\begin{array}{l}\text { In } \\
\text { vitro }\end{array}$ & Asiatic acid & $\begin{array}{l}\text { Human aortic } \\
\text { endothelial cells } \\
\text { (HAECs). }\end{array}$ & $N F-\kappa B$ & sE-selectin $\downarrow$, sICAM- $1 \downarrow, p-\mid \kappa B \alpha \downarrow$, VCAM- $1 \downarrow$ & $\begin{array}{l}\text { (Fong et al., } \\
\text { 2016) }\end{array}$ \\
\hline
\end{tabular}

TGF- $\beta$, transforming growth factor beta; SP, systolic blood pressure; DP, diastolic blood pressure; MAP, mean arterial blood pressure; HBF, hindlimb blood flow; HVR, hindlimb vascular resistance; Ang II, angiotensin II; FS, fractional shortening; LVEDD, left ventricular end-diastolic diameter; a-SMA, a-smooth muscle actin; LVESV, left ventricular end systolic volume; HR, heart rate; $L D H$, lactate dehydrogenase; CK, creatine kinase; eNOS, endothelial nitric oxide synthase; cGMP, cyclic guanosinc monophosphate; MLC, myosin light chain; ZO-1, zona occludens -1; HIF-1a, hypoxia-inducible factor 1a.

failure, which is controlled by the TGF- $\beta /$ Smads pathway. Smad 2 and Smad 3 are the two main downstream regulators of TGF- $\beta 1$ mediated tissue fibrosis, and Smad7 is a negative feedback regulator (Hu et al., 2018; de Boer et al., 2019). Cardiovascular diseases can cause a variety of pathological changes and affect the development of related pathology by affecting Ang II/AT1R and TGF- $\beta$ /Smads signaling pathways. Wang X. B. et al. (2015) found that asiaticoside reduced mean pulmonary artery pressure and right ventricular hypertrophy by inhibiting the overexpressed TGF- $\beta 1 / \mathrm{Smad} 2 / 3$ signaling pathway in the hypoxia-induced pulmonary hypertension rat model. In 2017, Wang et al. further confirmed that asiaticoside effectively reduced the apoptotic factor (caspase-3), increasing the production of NO by activating the Akt/eNOS pathway. They confirmed that asiaticoside protected pulmonary hypertension by affecting endothelial cell function effect (Wang X. et al., 2018). And asiatic acid has anti- hypertensive and anti-inflammatory effects. In animal models of renovascular hypertension, it can play the role of angiotensinconverting enzyme (ACE)by inhibiting the Ang II-AT1RNicotinamide adenine dinucleotide phosphate (NADPH) signaling pathway. Moreover, it can reduce the inflammatory response (TNF- $\alpha \downarrow$, phospho-NF- $\kappa \mathrm{B} \downarrow$, IL-6 $\downarrow$ ) (Si et al., 2015; Maneesai et al., 2017). A clinical prospective, placebo-controlled, randomized, dose range trial found that after 4 weeks of treatment with $C$. asiatica total triterpenes (TTFCA), the capillary filtration rate, ankle circumference and ankle edema of patients with venous hypertension were improved, and the dose range showed that 180 $\mathrm{mg}$ /day was most effective in symptoms improvement (De Sanctis et al., 2001).

Atherosclerosis is a disease in which the inside of arteries narrows due to the buildup of plaque, leading to some serious problems such as heart attack, stroke, or even death. Maintaining 
arterial integrity and retaining endothelial barrier function and normal contraction of smooth muscle can limit the development of atherosclerotic disease (Döring et al., 2017). Asiaticoside has been found to reduce endothelial permeability; it can effectively protect the occurrence of atherosclerosis by lowering the levels of intercellular adhesion molecule-1, vascular cell adhesion molecule-1, and E-selectin. Moreover, it can also reduce the levels of related inflammation factor (IL-18) and has antiinflammation effects (Fong et al., 2015; Jing et al., 2018). A cell experiment found that asiatic acid reduced atherosclerosis by inhibiting the redistribution of occludin and zona occludens -1 (ZO-1). Furthermore, it decreased F-actin rearrangement and myosin light chain (MLC)dephosphorylation (Fong et al., 2019). Clinical studies have shown that after 4 years of intervention in patients with Pycnogenol ${ }^{\circledR} 100 \mathrm{mg}$ /day plus C. asiatica (100 mg/ day), the combined treatment group has reduced plaque progression, reduced oxidative stress, and mild transient brain deficiency as compared to the control group. The incidence of angina events in combined treatment group was less than $3 \%$, while the control group it was $6.25 \%$. Therefore, it can be established that $C$. asiatica may have a role in preventing preclinical atherosclerosis (Belcaro et al., 2015; Belcaro et al., 2017). For improving the inflammation response, reducing oxidative stress and retaining the endothelial barrier function have beneficial effects on the occurrence and development of atherosclerosis.

In myocardial ischemic disease, apoptosis is the main cause of cardiomyocyte death ( $\mathrm{Li}$ et al., 2020), and asiatic acid could reduce the levels of apoptotic factors (Bax/Bcl-2, caspase-9, caspase-3) and improve cardiomyocyte apoptosis ( $\mathrm{Si}$ et al., 2015; Huang et al., 2016). It can also improve the fibrotic changes caused by myocardial dysfunction by affecting the TGF-b1-Smad2/3 signaling pathway. In addition, Rosdah et al. (2019) pointed out that after administering C. asiatica extract to rats at doses $200 \mathrm{mg} / \mathrm{kg}$ and $400 \mathrm{mg} / \mathrm{kg}$ for 21 days, the content of acetylcholine (ACh) in heart was modulated significantly, which might contribute to its cardioprotective effect. A summary of the related literature (Table 5) showed that asiatic acid and asiaticoside had beneficial effects on cardiovascular diseases. Basic experiments confirmed that these two triterpenoids effectively improved hypertension, atherosclerosis, and myocardial ischemia.

TABLE 6 | Effects on digestive diseases.

\begin{tabular}{|c|c|c|c|c|c|c|}
\hline $\begin{array}{l}\text { Disease } \\
\text { model }\end{array}$ & Type & $\begin{array}{l}\text { Solvent composition } \\
\text { of extract }\end{array}$ & Animal/cell & $\begin{array}{l}\text { Signaling } \\
\text { pathway }\end{array}$ & Major findings & References \\
\hline Liver fibrosis & In vivo & Asiatic acid & Male SD rats & $\begin{array}{l}\text { PI3K/Akt/ } \\
\text { mTOR }\end{array}$ & $\begin{array}{l}\text { Bcl- } 2 \uparrow, \text { Bax } \downarrow \text {, caspase-3 } \downarrow, \alpha-S M A \downarrow, \text { p-AKT } \downarrow, \text { p-mTOR } \downarrow \text {, } \\
\text { p70S6K } \downarrow, \text { MDA } \downarrow \text {, SOD } \uparrow, \text { GSH-Px } \uparrow, \text { TGF- } \beta 1 \downarrow \text {, Cox- } 2 \downarrow, \text { TNF- } \alpha \downarrow \text {, } \\
\text { IL-6 } \downarrow, \text { IL-1 } \downarrow \downarrow\end{array}$ & $\begin{array}{l}\text { (Wei et al., } \\
\text { 2018) }\end{array}$ \\
\hline $\begin{array}{l}\text { Drug-induced } \\
\text { liver toxicity }\end{array}$ & In vivo & ECa233 & $\begin{array}{l}\text { Adult male } \\
\text { Wistar rats }\end{array}$ & - & TBARS $\downarrow, \mathrm{SOD} \uparrow, \mathrm{CAT} \uparrow$ & $\begin{array}{l}\text { (Intararuchikul } \\
\text { et al., 2019) }\end{array}$ \\
\hline $\begin{array}{l}\text { Acute liver } \\
\text { failure }\end{array}$ & In vivo & Madecassoside & Male KM mice & $\begin{array}{l}\mathrm{p} 38 / \mathrm{NF}- \\
\mathrm{\kappa B}, \mathrm{Nrf2/} \\
\mathrm{HO}-1\end{array}$ & $\begin{array}{l}\text { TNF- } \alpha \downarrow, I L-1 \beta \downarrow, I L-6 \downarrow, \text { SOD } \uparrow, \text { CAT } \uparrow, \text { GPx } \uparrow, \text { COX-2 } \downarrow, N F-\kappa B \\
\text { p65 } \downarrow, \text { p38 MAPK } \downarrow \text {, iNOS } \downarrow, \text { Nrf } 2 \uparrow, \mathrm{HO}-1 \uparrow\end{array}$ & $\begin{array}{l}\text { (Wang W. } \\
\text { et al., 2018) }\end{array}$ \\
\hline Liver injury & In vivo & Ethanol extract of CA & Male SD rats & - & $\begin{array}{l}\mathrm{MDA} \downarrow, \mathrm{SOD} \uparrow, \mathrm{GPx} \uparrow, \mathrm{CAT} \uparrow,\|\mathrm{L}-1 \beta \downarrow,\| \mathrm{L}-2 \downarrow, \| \mathrm{L}-6 \downarrow, \mathrm{L}-10 \downarrow, \mathrm{IL} \\
-12 \downarrow, \mathrm{TNF}-\alpha \downarrow, \mathrm{IFN}-\gamma \downarrow\end{array}$ & $\begin{array}{l}\text { (Choi et al., } \\
\text { 2016) }\end{array}$ \\
\hline $\begin{array}{l}\text { Acute } \\
\text { pancreatitis }\end{array}$ & $\begin{array}{l}\text { In vivo } \\
+ \text { in } \\
\text { vitro }\end{array}$ & Asiatic acid & $\begin{array}{l}\text { Male BALB/C } \\
\text { mice ; pancreatic } \\
\text { acinar cells }\end{array}$ & - & $\begin{array}{l}\text { Serum amylase } \downarrow \text {, serum lipase } \downarrow, N F-\kappa B \text { p65 } \downarrow \text {, IкB- } \beta \uparrow, \mid L-1 \beta \downarrow \text {, IL- } \\
6 \downarrow, \text { TNF- } \alpha \downarrow, \text { MPO } \downarrow\end{array}$ & $\begin{array}{l}\text { (Xiao et al., } \\
2017)\end{array}$ \\
\hline $\begin{array}{l}\text { Colon } \\
\text { carcinogenesis }\end{array}$ & In vivo & Asiatic acid & $\begin{array}{l}\text { Male albino } \\
\text { Wistar rats }\end{array}$ & - & $\begin{array}{l}\text { TBARS } \downarrow, \text { CD } \downarrow, \mathrm{LOOH} \downarrow \text {, SOD } \uparrow, \text { CAT } \uparrow \text {, cytochromeP450 } \downarrow \text {, } \\
\text { cytochrome P4502E } 1 \downarrow \text {, GST } \uparrow, \beta \text {-glucuronidase } \downarrow \text {, mucinase } \downarrow \text {, } \\
\text { LPO } \downarrow, \text { GSH } \uparrow, \text { GPX } \uparrow, \text { GR } \uparrow, \text { VitC } \downarrow, \text { VitE } \downarrow\end{array}$ & $\begin{array}{l}\text { (Siddique } \\
\text { et al., 2017) }\end{array}$ \\
\hline Colitis & $\begin{array}{l}\text { In vivo } \\
+ \text { in } \\
\text { vitro }\end{array}$ & $\begin{array}{l}\text { Madecassoside, } \\
\text { asiaticoside, } \\
\text { madecassic acid, } \\
\text { asiatic acid }\end{array}$ & $\begin{array}{l}\text { Female C57BL/6 } \\
\text { mice, EL-4 cells }\end{array}$ & $\begin{array}{l}\text { PPAR } / \\
\text { AMPK/ } \\
\text { ACC1 }\end{array}$ & 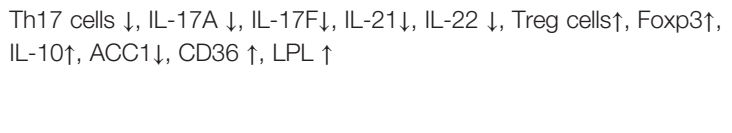 & $\begin{array}{l}\text { (Xu et al., } \\
2017)\end{array}$ \\
\hline $\begin{array}{l}\text { Gastric } \\
\text { mucosal injury }\end{array}$ & In vivo & Ethanol extract of CA & Male SD rats & - & iNOS $\downarrow$, TNF- $\alpha \downarrow$, MDA $\downarrow$, COX- $2 \downarrow$ & $\begin{array}{l}\text { (Zheng et al., } \\
\text { 2016a) }\end{array}$ \\
\hline $\begin{array}{l}\text { Helicobacter } \\
\text { pylori infection }\end{array}$ & In vivo & Ethanol extract of CA & $\begin{array}{l}\text { Specific } \\
\text { pathogen-free } \\
\text { male C57BL/6 } \\
\text { mice }\end{array}$ & - & H. pylori SS1 gastric colonization $\downarrow$ & $\begin{array}{l}\text { (Zheng et al., } \\
\text { 2016b) }\end{array}$ \\
\hline $\begin{array}{l}\text { Hepatocellular } \\
\text { carcinoma }\end{array}$ & $\begin{array}{l}\text { In } \\
\text { vitro }\end{array}$ & Asiatic acid & HepG2 & - & $\mathrm{MMP} \downarrow, \mathrm{Ca}^{2+} \uparrow, \mathrm{ATP} \downarrow$, cytochrome $\mathrm{c} \uparrow$, mitochondrial swelling $\downarrow$ & $\begin{array}{l}\text { (Lu et al., } \\
\text { 2016) }\end{array}$ \\
\hline Colon cancer & $\begin{array}{l}\text { In } \\
\text { vitro }\end{array}$ & Asiatic acid & $\begin{array}{l}\text { SW } 480 \text { and } \\
\text { HCT116 }\end{array}$ & $\begin{array}{l}\text { PI3K/Akt/ } \\
\text { mTOR/ } \\
\text { p70S6K }\end{array}$ & $\begin{array}{l}\text { E-cadherin } \uparrow \text {, vimentin } \downarrow, \mathrm{N} \text {-cadherin } \downarrow, \mathrm{p}-\mathrm{PI} 3 \mathrm{~K} \downarrow, \mathrm{p}-\mathrm{Akt} \downarrow, \mathrm{p} \\
\text {-mTOR } \downarrow \text {, p-p70S6K } \downarrow\end{array}$ & $\begin{array}{l}\text { (Hao et al., } \\
2018)\end{array}$ \\
\hline Gastric ulcers & $\begin{array}{l}\text { In } \\
\text { vitro }\end{array}$ & $\begin{array}{l}\text { Pentacyclic triterpene- } \\
\text { rich Centella extract } \\
\text { (PRE) }\end{array}$ & $\begin{array}{l}\text { Human gastric } \\
\text { epithelialcell lines }\end{array}$ & - & Cell viability $\uparrow$, cell migration $\uparrow$, wound closure $\uparrow$ & $\begin{array}{l}\text { (Wannasarit } \\
\text { et al., 2019) }\end{array}$ \\
\hline
\end{tabular}

TBARS, thiobarbituric acid reactive substances; CD, conjugated dienes; $L O O H$, lipid hydroperoxides; LPO, lipid peroxidation; GR, glutathione reductase; LPL, lipoprotein lipase. 


\section{Effects on Digestive Diseases}

C. asiatica and its triterpenoids also have therapeutic effects on digestive disorders, which is mainly reflected by improved liver fibrosis, colitis, and gastric mucosal damage; and even reduced Helicobacter pylori gastric colonization (Table 6).

Chronic and recurrent liver injuries are often accompanied by inflammatory reactions and often develop into liver fibrosis. Therefore, treating chronic and uncontrolled inflammation is a strategy to prevent liver injury and fibrosis (Campana and Iredale, 2017; Nguyen-Lefebvre et al., 2018). The pathological mechanism of gastric mucosal injury is complex, and nonsteroidal anti-inflammatory drugs are relatively common causes (Soll et al., 1991). Prostaglandin biosynthesis is one of the basic components that maintain the integrity of gastric mucosa, and cyclooxygenase is essential in the process of prostaglandin synthesis. The malondialdehyde (MDA) level can reflect the ROS level (Kwiecien et al., 2012). Therefore, an oxidative stress response is also crucial in the process of gastric mucosal injury. The present study found that the $C$. asiatica extract effectively ameliorated the drug-induced liver toxicity, improved gastric mucosal injury, and reduced $H$. pylori infection. The mechanisms involved were as follows: the reduction of related inflammation factors (IL-1 $\beta \downarrow$, IL-2 $\downarrow$, IL-6 $\downarrow$, IL-10 $\downarrow$, IL-12 $\downarrow$, and TNF- $\alpha \downarrow$ ) and the increase in the level of antioxidant stress factors (SOD $\uparrow$, CAT $\uparrow$, and GPx $\uparrow$ ). Furthermore, evidence showed that $C$. asiatica could also reduce $\mathrm{MDA}$ and COX-2 levels, thereby ameliorating gastric mucosal damage (Choi et al., 2016; Zheng et al., 2016a; Zheng et al., 2016b; Intararuchikul et al., 2019; Wannasarit et al., 2019). The pharmacological effect of asiatic acid is mainly reflected in the improvement in liver fibrosis and acute pancreatitis. It also has a certain therapeutic effect on gastrointestinal tumors. Three mechanisms are reported in the studies: asiatic acid can reduce the level of pro-apoptotic factors (B-cell lymphoma 2(Bcl-2) $\uparrow$, Bcl-2-associated X protein(Bax) $\downarrow$, caspase-3 $\downarrow$ ), and related inflammation factors (TGF- $\beta 1 \downarrow$, TNF- $\alpha \downarrow$, IL- $6 \downarrow$, IL- $1 \beta \downarrow$ ), and increase the level of anti-oxidative stress factors (SOD $\uparrow$, GSH-Px $\uparrow$, CAT $\uparrow$, GST $\uparrow$, GSH $\uparrow$ ) (Xiao et al., 2017; Siddique et al., 2017; Wei et al., 2018.). The study on madecassoside found that it could ameliorate drug-induced acute liver failure by reducing inflammation (TNF- $\alpha \downarrow$, IL-1 $\beta \downarrow$, IL- $6 \downarrow$, iNOS $\downarrow$, COX $-2 \downarrow$ ) and oxidative stress (SOD $\uparrow$, CAT $\uparrow$, GPx $\uparrow$, Nrf $2 \uparrow$, HO- $1 \uparrow$ ) (Wang W. et al., 2018). Oral administration of the four components of $C$. asiatica could attenuate colitis in mice, but it's mainly madecassoside acid, the active form of madecassoside, when topically administered in the colon, weakened colitis by regulating Th17/Treg balance via affecting the PPAR $\gamma / \mathrm{AMPK} /$ ACC1 pathway (Xu et al., 2017).

Colon cancer and primary liver cancer are common types of cancers in the digestive system (Grandhi et al., 2016; Chen et al., 2020). The expression of E-cadherin and vimentin is considered of high reference value in the prognosis of colon cancer. The mitochondrial morphology and the cytosolic calcium level $\left[\mathrm{Ca}^{2+}\right]$ are indicators of the pathological development of hepatocellular carcinoma (Zhang et al., 2011; Huang et al., 2017). Asiatic acid can also affect the expression of epithelial-mesenchymal transition marker proteins in colon cancer cells (E cadherin $\uparrow$, vimentin $\downarrow, \mathrm{N}$-cadherin $\downarrow$ ), achieved this anti-cancer potential by regulating $\mathrm{PI} 3 \mathrm{~K} / \mathrm{Akt} / \mathrm{mTOR} / \mathrm{p} 70 \mathrm{~S} 6 \mathrm{~K}$ signaling pathway. In addition, asiatic acid can induce the dissipation of mitochondrial membrane potential (MMP), ATP depletion, release of cytochrome $\mathrm{c}$ from mitochondria into the cytosol of HepG2 cells, which may induce the death of liver cancer cells by directly affecting mitochondrial function, it may be a potential therapeutic drug for liver cancer and colon cancer ( $\mathrm{Lu}$ et al., 2016; Hao et al., 2018).

Based on the aforementioned evidence, it was concluded that C. asiatica maybe can improve liver, colon and stomach related digestive disorders by reducing inflammation, ameliorating oxidative stress, and improving mitochondrial function.

\section{Effects on Respiratory Diseases}

The effects of $C$. asiatica on respiratory diseases is mainly reflected in its ability to improve pulmonary fibrosis, ameliorate chronic obstructive pulmonary disease, and decrease lung injury and certain anti-lung cancer effects (Table 7).

Pulmonary fibrosis can be induced by a variety of injuries to the lung. It is characterized by fibroblast/myofibroblast activation and excessive extracellular matrix accumulation, leading to a progressive organ dysfunction mainly including varying degrees of inflammation and fibrosis (Selman and Pardo, 2002; Thannickal et al., 2004). By reducing collagen accumulation, pulmonary fibrosis can be effectively improved through TGF- $\beta 1$ and NLRP3 pathways and decreasing the levels of inflammation factors (Nie et al., 2017; Tian et al., 2017). Chronic obstructive pulmonary disease (COPD) is a frequently progressive inflammatory disease of the respiratory tract, alveoli, and microvasculature. The pathological mechanism of COPD is that airway epithelial cell damage triggers nonspecific inflammatory responses by releasing endogenous intracellular molecules or molecular patterns associated with danger. Impaired immune regulation may play a major role in COPD (Rabe and Watz, 2017). For the treatment of COPD, it is generally recommended to use appropriate long-acting maintenance bronchodilators and inhaled corticosteroids; pulmonary rehabilitation can also relieve symptoms (Riley and Sciurba, 2019). However, corticosteroid treatment has certain side effects. Lung cancer is the most common cause of cancerrelated mortality in the world. Different treatment methods for lung cancer are generally selected according to the stages, such as surgery, radiation therapy, molecular targeted therapy, and immunotherapy (Hirsch et al., 2017; Quaratino et al., 2017). Acute lung injury (ALI) is a systemic inflammation of the lungs manifested as hypoxia, edema, and pulmonary infiltrates present in the chest cavity. ALI is characterized by (1) epithelial and vascular permeability increased, (2) hypercoagulation and insufficient fibrinolysis, and (3) inflammation and immune regulation (McVey et al., 2012).

This review found that pretreatment with asiatic acid can inhibit bleomycin-induced lung injury and fibrosis in mice. It can down-regulate the expression of pro-inflammatory factors, inhibit inflammatory cells infiltration and expression of 
TABLE 7 | Effects on respiratory diseases.

\begin{tabular}{|c|c|c|c|c|c|c|}
\hline $\begin{array}{l}\text { Disease } \\
\text { model }\end{array}$ & Type & $\begin{array}{l}\text { Solvent } \\
\text { composition } \\
\text { of extract }\end{array}$ & Animal/cell & $\begin{array}{l}\text { Signaling } \\
\text { pathway }\end{array}$ & Major findings & References \\
\hline $\begin{array}{l}\text { Pulmonary } \\
\text { fibrosis }\end{array}$ & $\begin{array}{l}\text { In } \\
\text { vivo } \\
+ \text { in } \\
\text { vitro }\end{array}$ & Asiatic acid & $\begin{array}{l}\text { Male C57BL/6, human lung } \\
\text { fibroblasts MRC- } 5 \text { cells and } \\
\text { mouse lung epithelial cells MEL- } \\
12\end{array}$ & - & $\begin{array}{l}\text { Collagen levels } \downarrow \text {, inspiratory resistance } \downarrow \text {, expiratory resistance } \downarrow \text {, } \\
\text { collagen I } \downarrow \text {, collagen III } \downarrow, \alpha \text {-SMA } \downarrow \text {, Vimentin } \downarrow \text {, E-cadherin } \uparrow \text {, } \\
\text { TGF- } \beta 1 \downarrow \text {, fibronectin } \downarrow, \text { p-ERK } 1 / 2 \downarrow, I L-1 \beta \downarrow, I L-18 \downarrow, I L-6 \downarrow \text {, TNF- } \\
\text { a } \downarrow \text {, NLRP3 } \downarrow\end{array}$ & $\begin{array}{l}\text { (Dong et al., } \\
\text { 2017) }\end{array}$ \\
\hline $\begin{array}{l}\text { Chronic } \\
\text { obstructive } \\
\text { pulmonary } \\
\text { disease }\end{array}$ & $\begin{array}{l}\text { In } \\
\text { vivo }\end{array}$ & Asiatic acid & Male C57BL/6 & $\begin{array}{l}\text { NF-кB, } \\
\text { MAPKs }\end{array}$ & $\begin{array}{l}\text { Neutrophils } \downarrow \text {, macrophages } \downarrow \text {, NE } \downarrow \text {, TNF- } \alpha \downarrow \text {, IL-6 } \downarrow \text {, MCP- } 1 \downarrow \text {, } \\
\text { p-ERK } \downarrow, p-p 38 \downarrow, p-J N K \downarrow, p-p 65 \downarrow, p-I k B \downarrow, \text { HO- } 1 \uparrow, \text { SOD3 } \uparrow\end{array}$ & $\begin{array}{l}\text { (Lee et al., } \\
\text { 2016) }\end{array}$ \\
\hline $\begin{array}{l}\text { Lung } \\
\text { cancer }\end{array}$ & $\begin{array}{l}\text { In } \\
\text { vitro } \\
\text { and } \\
\text { in } \\
\text { vivo }\end{array}$ & Asiatic acid & $\begin{array}{l}\text { Human A549 and H1299 lung } \\
\text { cancer cell lines and mouse } \\
\text { Lewis lung cancer (LLC) cells, } \\
\text { C57BL/6J mice }\end{array}$ & - & $\begin{array}{l}\text { Caspase- } 9 \uparrow \text {, caspase-3 } \uparrow, \text { LC3-I } \downarrow \text {, LC3-II } \uparrow, \text { p62 } \downarrow \text {, tumor } \\
\text { volume } \downarrow\end{array}$ & $\begin{array}{l}\text { (Wu et al., } \\
\text { 2017) }\end{array}$ \\
\hline $\begin{array}{l}\text { Acute lung } \\
\text { injury }\end{array}$ & $\begin{array}{l}\text { In } \\
\text { vitro } \\
\text { and } \\
\text { in } \\
\text { vivo }\end{array}$ & Asiaticoside & $\begin{array}{l}\text { Male BALB/c mice, RAW } 264.7 \\
\text { mouse macrophage cell line }\end{array}$ & $N F-\kappa B$ & TNF- $\alpha \downarrow,|L-6 \downarrow, p-| \kappa B \downarrow, p-p 65 \downarrow$ & $\begin{array}{l}\text { (Qiu et al., } \\
\text { 2015) }\end{array}$ \\
\hline $\begin{array}{l}\text { Lung } \\
\text { cancer }\end{array}$ & $\begin{array}{l}\text { In } \\
\text { vitro }\end{array}$ & $\begin{array}{l}\text { C. asiatica } \\
\text { semi-purified } \\
\text { fraction-3 (C3) }\end{array}$ & Cancerous lung A549 cells & - & $\begin{array}{l}\text { MDA } \uparrow, \text { IROS } \uparrow, \text { GSH } \uparrow, \text { GSSG } \downarrow \text {, Nrf- } 2 \uparrow, \text { GPx } \uparrow, \text { SOD } \uparrow, \text { LDH } \uparrow, \\
\text { caspase- } 8 \uparrow \text {, caspase- } 9 \uparrow \text {, caspase-3/7 } \uparrow, \text { ATP } \downarrow, \text { p53 } \downarrow \text {, Bax } \uparrow \\
\text { Bcl- } 2 \downarrow, \text { HSP-70 } \uparrow\end{array}$ & $\begin{array}{l}\text { (Naidoo } \\
\text { et al., 2017b) }\end{array}$ \\
\hline $\begin{array}{l}\text { Lung } \\
\text { cancer }\end{array}$ & $\begin{array}{l}\text { In } \\
\text { vitro }\end{array}$ & Asiatic acid & Human A549 lung cancer cell line & - & $\begin{array}{l}\text { Migration } \downarrow \text {, invasion } \downarrow \text {, Snail } \downarrow \text {, E-cadherin } \downarrow \text {, N-cadherin } \downarrow \text {, } \\
\text { vimentin } \downarrow\end{array}$ & $\begin{array}{l}\text { (Cui et al., } \\
\text { 2019) }\end{array}$ \\
\hline
\end{tabular}

NLRP3, PYD domains-containing protein 3; NE, neutrophil elastase; LC3, light chain 3; IROS, intracellular reactive oxygen species; LDH, lactate dehydrogenase; HSP-70, heat shock protein -70 .

transforming growth factor- $\beta 1$. In a mouse model, lung inflammation was induced by exposure to cigarette smoke, oral administration of asiatic acid reduced the excessive production of mucus in lung tissues, inhibited the release of proinflammatory factors, and induce the expression of HO-1, which may become a potential drug for the treatment of COPD by regulating key progressions (Lee et al., 2016; Dong et al., 2017). The common possible mechanism was that asiatic acid could reduce the level of related inflammation factors (IL- $6 \downarrow$, TNF- $\downarrow \downarrow$ ). In addition, asiatic acid can inhibit collagen deposition in lung fibrosis diseases (Lee et al., 2016; Dong et al., 2017). Cell and animal experiments found that asiatic acid could reduce tumor volume, tumor migration, and differentiation. Furthermore, it also has the ability to promote tumor cell apoptosis (caspase-9 $\uparrow$, caspase-3 $\uparrow$ ) (Wu et al., 2017; Cui et al., 2019). Therefore, asiatic acid may be a potential therapeutic drug for lung cancer. As for asiaticoside, the review found that it can reduce the inflammatory infiltration caused by lipopolysaccharide in a dose-dependent manner, and inhibit the inflammatory response in lung tissue by inhibiting the NF- $\kappa B$ signaling pathway(TNF- $\alpha \downarrow$, IL- $6 \downarrow$, p-IкB $\downarrow$, p-p65 $\downarrow$ ), which can be an effective preventive agent for ALI (Qiu et al., 2015).

Therefore, the present study showed that the effective components of C. asiatica on respiratory diseases were asiatic acid and asiaticoside, and the major mechanism was antiinflammation; this was also consistent with the pathological mechanism of the aforementioned diseases. Moreover, it is worth paying close attention to the potential therapeutic effect

TABLE 8 | Effects on gynecological diseases.

\begin{tabular}{|c|c|c|c|c|c|c|}
\hline $\begin{array}{l}\text { Disease } \\
\text { model }\end{array}$ & Type & $\begin{array}{l}\text { Solvent composition } \\
\text { of extract }\end{array}$ & Animal/cell & $\begin{array}{l}\text { Signaling } \\
\text { pathway }\end{array}$ & Major findings & References \\
\hline $\begin{array}{l}\text { Pelvic } \\
\text { inflammation }\end{array}$ & $\begin{array}{l}\text { In } \\
\text { vivo }\end{array}$ & Asiatic acid & Female SD rats & $\mathrm{NF}-\kappa \mathrm{B}$ & IL-1 $\beta \downarrow, \mid \mathrm{L}-6 \downarrow, \mathrm{TNF}-\alpha \downarrow, \mathrm{NLRP} 3 \downarrow, \mathrm{SOD} \uparrow$ & $\begin{array}{l}\text { (Kong et al., } \\
\text { 2019) }\end{array}$ \\
\hline $\begin{array}{l}\text { Ovarian } \\
\text { cancer }\end{array}$ & $\begin{array}{l}\text { In } \\
\text { vitro }\end{array}$ & Asiatic acid & $\begin{array}{l}\text { Ovarian cancer cell lines } \\
\text { (SKOV3 and OVCAR-3) }\end{array}$ & $\begin{array}{l}\text { PI3K/AKt/ } \\
\text { mTOR }\end{array}$ & $\begin{array}{l}\text { Caspase-9 } \uparrow \text {, caspase- } 3 \uparrow, \text { PARP } \uparrow, \text { Bax } \uparrow, \text { Bcl- } 2 \downarrow \text {, p-PI3K } \downarrow \text {, p- } \\
\text { Akt } \downarrow, \text { p-mTOR } \downarrow \text {, CDK } 2 \downarrow \text {, CDK } 4 \downarrow \text {, CDK } 6 \downarrow \text {, cyclin D1 } \downarrow \text {, cyclin } E \downarrow\end{array}$ & $\begin{array}{l}\text { (Ren et al., } \\
\text { 2016) }\end{array}$ \\
\hline Breast cancer & $\begin{array}{l}\text { In } \\
\text { vitro }\end{array}$ & Centella asiatica & $\begin{array}{l}\text { MCF-7 breast cancer } \\
\text { cell line }\end{array}$ & - & Caspase- $3 \uparrow$, caspase- $-9 \uparrow$ & $\begin{array}{l}\text { (Fard et al., } \\
\text { 2018) }\end{array}$ \\
\hline- & $\begin{array}{l}\text { In } \\
\text { vitro }\end{array}$ & Asiatic acid & $\begin{array}{l}\text { Parthenogenetic } \\
\text { embryos }\end{array}$ & & $\begin{array}{l}\text { ROS } \downarrow \text {, GSH } \uparrow, \text { MMP } \uparrow \text {, blastocyst formation } \uparrow, \text { SOD- } 1 \uparrow, \text { COX-2 } \\
\uparrow \text {, caspase- } 9 \downarrow\end{array}$ & $\begin{array}{l}\text { (Qi et al., } \\
\text { 2020) }\end{array}$ \\
\hline Endometriosis & $\begin{array}{l}\text { In } \\
\text { vitro }\end{array}$ & Asiatic acid & $\begin{array}{l}\text { Endometrial epithelial } \\
\text { cells }\end{array}$ & $\begin{array}{l}\text { TLR4/NF- } \\
\kappa B\end{array}$ & $\begin{array}{l}\text { TNF- } \alpha \downarrow, \mid L-1 \beta \downarrow, \text { NO } \downarrow, \text { PGE } 2 \downarrow, \text { TLR } 4 \downarrow, p-\mid \kappa B \alpha \downarrow, p-p 65 \downarrow \\
\text { PPAR } \gamma \uparrow\end{array}$ & $\begin{array}{l}\text { (Cao et al., } \\
\text { 2018) }\end{array}$ \\
\hline
\end{tabular}

PARP, antipoly (ADP-ribose) polymerase; CDK, cyclin-dependent kinase; PGE2, Prostaglandin E2; PPAR $\gamma$, peroxisome proliferator-activated receptor $\gamma$. 
of $C$. asiatica and asiatic acid on lung cancer. Also, the mechanisms of promoting apoptosis and inhibiting differentiation of tumor cells are worthy of further exploration.

\section{Effects on Gynecological Diseases}

C. asiatica can effectively improve endometriosis and relief pelvic inflammatory disease, as well as exert anti-ovarian cancer and anti-breast cancer functions (Table 8).

Pelvic inflammatory disease is a microbial infection of the upper reproductive tract. Its major complications are infertility, chronic pelvic pain, rupture of a renal tubular ovarian abscess, and ectopic pregnancy. Western medicine uses antibiotics to effectively control the symptoms (Jaiyeoba et al., 2011; Bugg and Taira, 2016). However, no conclusive evidence indicated that antibiotic treatment for the pelvic inflammatory disease was safer or more effective than other methods (Savaris et al., 2017). Endometriosis is a common inflammatory disease often accompanied by pelvic pain and infertility. Generally, surgeries are conducted to treat endometriosis, but accumulating evidence suggest the use of plant-based drugs for the treatment, and these medicines usually alleviate the symptoms via their antiinflammatory, anti-oxidant, anti-proliferation, and antiapoptotic effects (Audebert, 2018; Falcone and Flyckt-Rebecca, 2018; Bina et al., 2019). Ovarian cancer and breast cancer are the top two cancers in women (Anastasiadi et al., 2017; Stewart et al., 2019). Surgery, radiotherapy, chemotherapy, and other treatments are often associated with various complications. Therefore, exploring new therapeutic agents is particularly important.

Table 8 shows that asiatic acid can efficaciously treat pelvic inflammation. It has potential therapeutic effects on endometriosis and ovarian cancer (Ren et al., 2016; Cao et al., 2018; Kong et al., 2019). The main mechanism is reduction in the production of inflammatory body NLRP3 and inflammatory factors (IL-1 $\beta$, IL-6, TNF- $\alpha$ ), inhibition of the NF- $\mathrm{KB}$ signaling pathway, which regulates the production of inflammatory factors, and thus alleviation of pelvic inflammation. Cell experiments confirmed that asiatic acid can effectively improve the symptoms of endometriosis. The main mechanism is inhibition of the NF- $\kappa B$ pathway to reduce the production of inflammatory factors (TNF- $\alpha \downarrow$, IL- $1 \beta \downarrow$, p-IкB $\alpha$ $\downarrow$, p- p65 $\downarrow$ ) (Cao et al., 2018). The potential therapeutic value of asiatic acid for ovarian cancer is mainly reflected in that it can promote the apoptosis of ovarian cancer cells and inhibit the growth of ovarian cancer cells by affecting the cell cycle progression (Ren et al., 2016). In addition, studies found that asiatic acid improved the developmental ability of early embryos in pigs; the main underlying mechanism was amelioration of oxidative stress and downregulation of the expression of apoptosis-related genes (Qi et al., 2020). The potential therapeutic value of $C$. asiatica for breast cancer mainly reflected in the promotion of apoptosis of breast cancer cells (Fard et al., 2018).

Therefore, this study concluded that the therapeutic effect of C. asiatica on the gynecological diseases mainly reflected in the improvement in inflammation. The main research component was asiatic acid, which worked by affecting apoptosis, reducing the production of inflammatory factors and influencing the cell cycle progression. Therefore, asiatic acid may be a potential agent in the treatment of gynecological diseases, and further clinical trials are needed to verify its efficacy.

\section{Effects on Rheumatoid Arthritis}

Animal and cell experiments confirmed that madecassoside exerted an anti-rheumatoid effect (Table 9). Rheumatoid arthritis (RA) is a chronic inflammatory joint disease that usually affects women and elderly people; the main pathological change is persistent synovitis. If not controlled well, it can lead to joint deformities and other diseases and decrease patients' quality of life (Scott et al., 2010; Smolen et al., 2016). Studies confirmed that TNF- $\alpha$ is a powerful proinflammatory cytokine overexpressed in the synovium of patients with RA, and reducing TNF- $\alpha$ production can effectively improve the symptoms of rheumatoid arthritis (Marsal and Juliá, 2010). In addition, matrix metalloproteinase (MMP)-13 is a specific protein associated with RA, and may be involved in the physiological remodeling of synovial tissue (Konttinen et al., 1999).

The pharmacological study on madecassoside demonstrated that it can effectively lessen the related inflammatory factors in arthritis model rats (TNF- $\alpha \downarrow$, IL- $1 \mathrm{~b} \downarrow$, IL- $6 \downarrow$, IFN- $\gamma \downarrow$, IL-17 $\downarrow$ ). Animal experiments have confirmed that oral madecassoside (30 $\mathrm{mg} / \mathrm{kg}$ ) can significantly reduce the symptoms of arthritis, and can inhibit the secretion of inflammatory cytokines. However, in vitro experiments have found that madecassoside and madecassic acid, the main metabolite of madecassoside, cannot influence the secretion of inflammatory cytokines. It was subsequently suggested that madecassoside may exhibits antiarthritis potency through affecting the secretion of IL-10 from Foxp $3^{+}$cells in lamina propria of intestine, thus regulates the immune function of rats with collagen-induced arthritis (Wang T. et al., 2015). The results of madecassoside pharmacokinetics experiments are poor, but it has significant bioavailability, can effectively reverse adjuvant-induced arthritis, and inhibit the migration and invasion of fibroblast-like synovial cells,

TABLE 9 | Effects on rheumatoid arthritis.

\begin{tabular}{|c|c|c|c|c|c|c|}
\hline $\begin{array}{l}\text { Disease } \\
\text { model }\end{array}$ & Type & $\begin{array}{l}\text { Solvent composition } \\
\text { of extract }\end{array}$ & Animal/cell & $\begin{array}{l}\text { Signaling } \\
\text { pathway }\end{array}$ & Major findings & References \\
\hline $\begin{array}{l}\text { Rheumatoid } \\
\text { arthritis }\end{array}$ & In vivo & Madecassoside & Female Wistar rats & - & $\begin{array}{l}\text { TNF- } \alpha \downarrow, I \mathrm{IL}-1 \mathrm{~b} \downarrow, \mathrm{IL}-6 \downarrow, \mathrm{IFN}-\gamma \\
\downarrow, \mathrm{IL}-17 \downarrow, \mathrm{IL}-10 \uparrow\end{array}$ & $\begin{array}{l}\text { (Wang et al., } \\
\text { 2015) }\end{array}$ \\
\hline $\begin{array}{l}\text { Rheumatoid } \\
\text { arthritis }\end{array}$ & $\begin{array}{l}\text { In vivo + } \\
\text { in vitro }\end{array}$ & Madecassoside & $\begin{array}{l}\text { Adjuvant-induced arthritis model rats, fibroblast- } \\
\text { like synoviocytes (FLS) cells }\end{array}$ & $\begin{array}{l}\text { NF- } \kappa \mathrm{B} / \mathrm{MMP}- \\
13\end{array}$ & $\mathrm{MMP}-13$ mRNA $\downarrow, N F-\kappa B \downarrow$ & $\begin{array}{l}\text { (Yu et al., } \\
\text { 2018) }\end{array}$ \\
\hline
\end{tabular}


TABLE 10 | Effects on other diseases.

\begin{tabular}{|c|c|c|c|c|c|c|}
\hline Disease model & Type & $\begin{array}{l}\text { Solvent composition of } \\
\text { extract }\end{array}$ & Animal/cell & $\begin{array}{l}\text { signaling } \\
\text { pathway }\end{array}$ & Major findings & References \\
\hline Leukemia & In vitro & $\begin{array}{l}\text { C. asiatica ethanolic leaf } \\
\text { extract }\end{array}$ & THP-1 cells & - & $\begin{array}{l}\text { Cell viability } \downarrow \text {, TNF- } \alpha \uparrow, I L-1 \beta \downarrow, I L-6 \downarrow, I L-10 \uparrow, \text { GSH } \uparrow \text {, } \\
\text { caspase-9, caspase-3/7) } \downarrow, \text { ATP } \downarrow\end{array}$ & $\begin{array}{l}\text { (Naidoo et al., } \\
2017 \text { a) }\end{array}$ \\
\hline $\begin{array}{l}\text { Ischemic } \\
\text { retinopathies }\end{array}$ & In vitro & Madecassic acid & hRMECs & $\begin{array}{l}\text { PERK } \\
\text { elF2a }\end{array}$ & $\begin{array}{l}\text { Cell viability } \uparrow, \text { SOD } \uparrow, \text { GSH-PX } \uparrow, \text { LDH } \downarrow \text {, MDA } \downarrow \text {, caspase-3 } \\
\downarrow \text {, caspase- } 9 \downarrow \text {, Bax/Bcl- } 2 \downarrow, \text { GRP78 } \downarrow, \text { CHOP } \downarrow \text {, ATF6 } \downarrow \text {, } \\
\text { IRE1a } \downarrow \text {, PERK } \downarrow \text {, elF2a } \downarrow\end{array}$ & $\begin{array}{l}\text { (Yang et al., } \\
\text { 2016) }\end{array}$ \\
\hline $\begin{array}{l}\text { Doxorubicin } \\
\text { (DXR)-induced } \\
\text { organ toxicities }\end{array}$ & In vivo & Asiatic acid & Wistar rats & - & $\begin{array}{l}\text { CK-MB } \downarrow, \text { LDH } \downarrow, \text { SGPT } \downarrow, \text { SGOT } \downarrow, \text { BUN } \downarrow \text {, creatinine } \downarrow \text {, SOD } \\
\uparrow, \text { GSH } \uparrow, \text { LPO } \downarrow, \text { Nrf2 } \uparrow\end{array}$ & $\begin{array}{l}\text { (Kamble and } \\
\text { Patil, 2018) }\end{array}$ \\
\hline Drug resistance & In vitro & Asiatic acid & $\begin{array}{l}\text { Cisplatin- } \\
\text { resistant A549/ } \\
\text { DDP cells }\end{array}$ & $\begin{array}{l}\text { NF-kB, } \\
\text { MAPKV } \\
\text { ERK }\end{array}$ & $\begin{array}{l}\text { DDP resistance } \downarrow \text {, DDP sensitivity } \uparrow, \text { MDR } 1 \downarrow, \text { p65 } \downarrow \text {, Akt } \downarrow \text {, } \\
\text { YB1 } \downarrow, p-E R K 1 / 2 \downarrow, p-J N K \downarrow, p-p 38 \downarrow, p-l k B \alpha \downarrow\end{array}$ & $\begin{array}{l}\text { (Cheng et al., } \\
\text { 2018) }\end{array}$ \\
\hline $\begin{array}{l}\text { Oral submucous } \\
\text { fibrosis }\end{array}$ & In vitro & $\begin{array}{l}\text { Ethanolic extract of CA, } \\
\text { Asiatic acid }\end{array}$ & $\begin{array}{l}\text { Primary human } \\
\text { buccal } \\
\text { fibroblasts(HBF) }\end{array}$ & $\begin{array}{l}\text { TGF } \beta / \\
\text { Smad }\end{array}$ & $\begin{array}{l}\text { TGF } \beta 1 \downarrow \text {, COL1A2 } \downarrow \text {, COL3A } 1 \downarrow \text {, extracellular matrix (ECM) } \\
\text { deposition } \downarrow\end{array}$ & $\begin{array}{l}\text { (Adtani et al., } \\
\text { 2017) }\end{array}$ \\
\hline- & In vitro & ECa 233 & $\begin{array}{l}\text { RAW264.7 } \\
\text { macrophages }\end{array}$ & MAPK & ROS $\downarrow$, NO $\downarrow$, PGE2 $\downarrow$, TNF- $\alpha \downarrow, I L-1 \beta \downarrow$, COX- $2 \downarrow$, iNOS $\downarrow$ & $\begin{array}{l}\text { (Sukketsiri } \\
\text { et al., 2019) }\end{array}$ \\
\hline- & In vitro & Asiatic acid & HepG2 cells & Nrf2 & ROS $\downarrow$, apoptosis $\downarrow$, Nrf2 $\uparrow$, Keap $1 \downarrow, \mathrm{HO}-1 \uparrow, \mathrm{NQO}-1 \uparrow, \mathrm{GCLC} \uparrow$ & $\begin{array}{l}\text { (Qi et al., } \\
\text { 2017) }\end{array}$ \\
\hline Sepsis & $\begin{array}{l}\text { In vivo } \\
+ \text { In } \\
\text { vitro }\end{array}$ & Asiatic acid & $\begin{array}{l}\text { BALB/c mice, } \\
\text { RAW264.7 cells }\end{array}$ & Notch & $\begin{array}{l}\text { neutrophil infiltration } \downarrow \text {, ALT } \downarrow \text {, BUN } \downarrow,\|L-1 \beta \downarrow,\| L-6 \downarrow, \text { NO } \downarrow \text {, } \\
\text { Notch3 } \downarrow \text {, D\|4 } \downarrow \text {, ROS } \downarrow, \text { MMP } \downarrow \text {, ATP } \downarrow\end{array}$ & $\begin{array}{l}\text { (Yuyun et al., } \\
\text { 2018) }\end{array}$ \\
\hline Migraine & In vivo & $\begin{array}{l}\text { Asiaticoside (AS)-based } \\
\text { standardized extract of } \\
\text { Centella asiatica }\end{array}$ & Wistar rats & - & Hyperalgesia $\downarrow, 5-H T \uparrow$, vocalization $\downarrow$, pain latency $\uparrow$ & $\begin{array}{l}\text { (Bobade } \\
\text { et al., 2015) }\end{array}$ \\
\hline Glaucoma & In vivo & Asiatic acid & Wistar rats, & - & RGCs $\uparrow$, Bcl- $2 \uparrow$, Bax $\downarrow$, caspase- $3 \downarrow$ & $\begin{array}{l}\text { (Huang et al., } \\
\text { 2018) }\end{array}$ \\
\hline- & $\begin{array}{l}\text { In vitro } \\
+ \text { in } \\
\text { vivo }\end{array}$ & Methanol extract of CA & $\begin{array}{l}\text { Swiss albino } \\
\text { male mice }\end{array}$ & MAPK & $\begin{array}{l}\text { Lipid peroxide } \downarrow \text {, superoxide } \downarrow \text {, hydroxyl radicals } \downarrow \text {, RNS } \downarrow \text {, IL- } \\
10 \uparrow, \text { IL- } 1 \downarrow \text {, MCP- } 1 \downarrow \text {, INF- } \gamma \downarrow \text {, TNF- } \beta \downarrow \text {, MAPK } 14 \downarrow\end{array}$ & $\begin{array}{l}\text { (Viswanathan } \\
\text { et al., 2019) }\end{array}$ \\
\hline Periodontitis & $\begin{array}{l}\text { In vivo } \\
+ \text { in } \\
\text { vitro }\end{array}$ & Asiatic acid & $\begin{array}{l}\text { Male SD rats, } \\
\text { HGFs, } \\
\text { RAW264.7 cells }\end{array}$ & $N F-\kappa B$ & PGE2 $\downarrow$, NO $\downarrow, \mid$ IL-8 $\downarrow, I L-6 \downarrow, p-p 65 \downarrow, p-\mid \kappa B \alpha \downarrow$, PPAR- $\gamma \uparrow$ & $\begin{array}{l}\text { (Hao et al., } \\
\text { 2017) }\end{array}$ \\
\hline- & In vitro & Asiaticoside & hPDL cells & $\begin{array}{l}\text { Wnt } / \beta- \\
\text { catenin }\end{array}$ & OSX $\uparrow$, WNT3A $\uparrow$, AXIN2 $\downarrow$, DMP $1 \uparrow$ & $\begin{array}{l}\text { (Fitri et al., } \\
\text { 2018) }\end{array}$ \\
\hline Toxic side effects & In vivo & Ethanolic extraction of CA & $\begin{array}{l}\text { Male Wistar } \\
\text { albino rats }\end{array}$ & - & $\begin{array}{l}\text { WBC } \downarrow \text {, TBARS } \downarrow \text {, SOD } \uparrow, \text { CAT } \uparrow, \text { GSH } \uparrow, \text { TSP } \uparrow \text {, albumin } \uparrow \text {, } \\
\text { ALT } \downarrow \text {, AST } \downarrow \text {, ALP } \downarrow \text {, globulin } \downarrow \text {, total bilirubin } \downarrow \text {, urea } \downarrow \text {, } \\
\text { creatinine } \downarrow\end{array}$ & $\begin{array}{l}\text { (Ghosh et al., } \\
\text { 2017) }\end{array}$ \\
\hline $\begin{array}{l}\text { Osteolytic bone } \\
\text { diseases }\end{array}$ & In vitro & Asiaticoside & $\begin{array}{l}\text { Bone marrow } \\
\text { macrophages } \\
\text { (BMMs) }\end{array}$ & $N F-\kappa B$ & $\begin{array}{l}\text { TRAcP-positive cells } \downarrow \text {, Ctsk } \downarrow \text {, Nfatc1 } \downarrow, V \text {-ATPase } d 2 \downarrow \text {, } \\
\text { NFAT } \downarrow \text {, cFos } \downarrow, \mathrm{Ca}^{2+} \text { oscillation } \downarrow \text {, IkB- } \alpha \uparrow, \text { p-ERK } \downarrow\end{array}$ & $\begin{array}{l}\text { (He et al., } \\
\text { 2019) }\end{array}$ \\
\hline
\end{tabular}

GRP78, glucose-regulated protein 78; CHOP, C/EBP homologous transcription factor; ATF6, activating transcription factor 6; IRE1a, inositolrequiring kinase/endonuclease 1 alpha; PERK, phosphorylation of pancreatic ER stress kinase; elF2a, eukaryotic initiation factor 2 alpha; CK-MB, Creatine kinase-MB; BUN, blood urea nitrogen; SGPT, serum glutamic pyruvic transaminase; SGOT, serum glutamic-oxaloacetic transaminase. DDP, cisplatin; MDR, multidrug resistance; YB1, Y-box binding protein 1; COL1A2, collagen 1A2; COL3A1, collagen 3A1; NQO-1, NAD(P)H: quinone oxidase; GCLC, glutamyl cysteine ligase catalytic subunit; Dll4, delta-like ligand; 5-HT, 5-hydroxytryptophan; RGCs, retinal ganglion cells; RNS, reactive nitrogen species; OSX, osterix; ALP, AXIN2, axis inhibition protein 2;DMP 1, dentin matrix protein1; TSP,total serum protein; ALP, alkaline phosphatase; TRACP, tartrate resistant acid phosphatase; Ctsk, cathepsin K; Nfatc1, V-ATPase d2; vacuolar-type $H^{+}$-ATPase V0 subunit d2; NFAT, nuclear factor of activated T-cells.

however, it has no effect on cell proliferation. Wei-GuangYU et al. pointed out that madecassoside may have anti-arthritis activity by inhibiting the NF- $\mathrm{KB} / \mathrm{MMP}-13$ pathway ( $\mathrm{Yu}$ et al., 2018).

In summary, madecassoside as a triterpene component of $C$. asiatica, may have anti-arthritis effect, and the underlying mechanism is reduction in the level of inflammatory factors.

\section{Effects on Other Diseases}

Besides the aforementioned diseases, the preclinical studies on $C$. asiatica and its triterpenoids reported its other positive effects listed in Table 10, including (1) protecting retinal blood vessels, (2) reducing toxic and side effects of drugs, (3) reducing drug resistance, and (4) promoting periodontal tissue regeneration. $C$. asiatica could also alleviate oral submucous fibrosis, sepsis, migraine, glaucoma, periodontitis, leukemia, and osteolytic bone diseases.

Moreover, the C. asiatica extract has a positive significance for leukemia, oral submucous fibrosis, migraine, and toxic side effects. Leukemia is mainly affected by increased activity of oxidative scavengers. In vitro experiments found that the activity of leukemic THP-1 cells treated with C. asiatica ethanolic leaf extract (CLE) decreased by $28.404 \%$. Also, the levels of IL- $1 \beta$ and IL- 6 decreased, but the level of IL-10 increased, which may reduce the cytokine-induced tumor immunosuppressive activity, cancer progression and cancer cachexia syndrome. Moreover, C. asiatica can also activate exogenous apoptosis pathways in THP-1 cells, and may reduce 
the proliferation of THP-1 cells by cutting down the levels of ATP. Therefore, it may be effective in treating leukemia cachexia (Naidoo et al., 2017a). In addition, C. asiatica was found to be effective in reversing the hyperalgesia and 5-hydroxytryptophan levels in the brain of migraine animal models. Compared with the positive control (sumatriptan, $42 \mathrm{mg} \mathrm{kg}^{-1}$ ), the oral treatment agent [asiaticoside (AS)-based standardized $C$. asiatica extract (30 $\mathrm{mg} \mathrm{kg}^{-1}, 7$ days)] was effective in reducing nociception in rats (Bobade et al., 2015). Furthermore, an in vitro experiment showed that $C$. asiatica also downregulated fibrotic markers (TGFb1 $\downarrow$, COL1A2 $\downarrow$, COL3A1 $\downarrow$ ) to reverse oral mucosal fibrosis caused by arecoline. Therefore, C. asiatica might have an anti-fibrotic effect (Adtani et al., 2017). Finally, an in vivo experiment found that C. asiatica at $100 \mathrm{mg} / \mathrm{kg}$ bw effectively reduced the side effects of isoniazid in the treatment of pulmonary tuberculosis. This oral dose restored abnormal indicators to normal or even close to normal levels as reflected by liver and kidney functions (Ghosh et al., 2017).

Asiatic acid can improve the side effects caused by antibiotics, reverse multidrug resistance (MDR), and reduce sepsis. It also has therapeutic potential for periodontitis and glaucoma. An in vivo experiment showed that asiatic acid had a visible effect on doxorubicin (DXR)-induced organ toxicities, showing the best effect at $20 \mathrm{mg} / \mathrm{kg}$ by affecting the expression of Nrf2 (Kamble and Patil, 2018). Doxorubicin causes the peroxidation of organs and reduces the activity of innate antioxidant factors (Sonawane et al., 2018) while upregulating the expression of Nrf2 effectively promotes antioxidant activity and protects cells from the damage caused by oxidative stress (Qi et al., 2017; Delgado-Wicke et al., 2020). In vivo and in vitro experiments also found that asiatic acid reduced the levels of inflammatory factors (IL-1 $\beta \downarrow$, IL- $6 \downarrow$ ) by affecting the Notch signaling pathway, weakened liver and kidney damage, and improved the survival rate in the experimental sepsis mice model (Yuyun et al., 2018). Asiatic acid may also provide therapeutic latent energy for periodontitis through influencing the NF- $\kappa B$ signaling pathway and reducing the levels of related inflammatory factors (IL- $8 \downarrow$, IL- $6 \downarrow$, p-p65 $\downarrow$, p-IкB $\alpha \downarrow$ ) (Hao et al., 2017). Finally, asiatic acid also has a potential therapeutic effect on glaucoma; it can improve the survival rate of retinal ganglion cells (RGCs) in the glaucoma rat model. More importantly, it can increase the level of anti-apoptotic factors (Bcl-2 $\uparrow$ ) while reducing the level of apoptotic factors (Bax $\downarrow$, caspase- $3 \downarrow$ ) (Huang et al., 2018).

Madecassic acid can ameliorate ischemic retinopathy. A cell experiment showed that madecassic acid reduced apoptosis and endoplasmic reticulum stress for hypoxia-induced human retinal microvascular endothelial cells (hRMECs). It also reversed cell dysfunction through affecting the oxidative stress of cells under hypoxic conditions (Yang et al., 2016).

Interestingly, in vitro experiments found that asiaticoside effectively promoted the osteogenic differentiation of human periodontal ligament and inhibited receptor activator of nuclear factor kappa B ligand (RANKL)-induced formation of osteoclasts, indicating its therapeutic potential for periodontal tissue regeneration and osteolytic diseases (Fitri et al., 2018; He et al., 2019).

In summary, $C$. asiatica and its triterpenoids have broad therapeutic potential. The specific mechanism mainly involves the following four aspects: (1) anti-inflammatory; (2) antioxidant; (3) anti-apoptosis; and (4) anti-fibrosis.

\section{Clinical Trials of C. asiatica}

Clinical studies (Table 11) found that C. asiatica effectively improved the cognitive function of stroke patients. Patients were divided into 3 groups and administered with 1,000 mg/ day, $750 \mathrm{mg} /$ day C. asiatica extract, and $3 \mathrm{mg} /$ day folic acid, respectively. The patients were treated at the acute phase of stroke infarction for 6 weeks. The cognitive function of the patients was evaluated by the MoCA-Ina test. The $1,000 \mathrm{mg} /$ day treatment group scored highest among the three. No significant difference was noticed in AST and ALT levels when compared with baselines. As shown in Table 11, patients had different degrees of side effects, such as constipation, skin itching and abdominal distension.). Regarding the safety and pharmacokinetics of C. asiatica in healthy volunteers from Thailand, Phanit Songvut et al. pointed out that daily oral doses (single or multiple) of $250 \mathrm{mg}$

TABLE 11 | Clinical trials of C. asiatica.

\begin{tabular}{|c|c|c|c|c|c|c|c|c|c|}
\hline Diseases & Extract/Formulation & Design & $\begin{array}{l}\text { Dose } \\
\text { regimen }\end{array}$ & Duration & $\begin{array}{l}\text { Case/ } \\
\text { Control }\end{array}$ & Main outcome & Side effects & $\begin{array}{l}\text { Follow- } \\
\text { up }\end{array}$ & References \\
\hline $\begin{array}{l}\text { Vascular } \\
\text { cognitive } \\
\text { Impairment }\end{array}$ & Gotu kola extract & - & $\begin{array}{l}750 \mathrm{mg} / \text { day } \\
\text { or } 1000 \mathrm{mg} / \\
\text { day }\end{array}$ & 6 weeks & $\begin{array}{c}17 / 17 / \\
14\end{array}$ & MoCA-Ina score $\uparrow$ & $\begin{array}{l}\text { Constipation, itching, bloated } \\
\text { feeling }\end{array}$ & 6 weeks & $\begin{array}{l}\text { (Farhana et al., } \\
\text { 2016) }\end{array}$ \\
\hline $\begin{array}{l}\text { Diabetic } \\
\text { neuropathy }\end{array}$ & $\begin{array}{l}\text { Centella } \\
\text { asiatica selected } \\
\text { triterpenes }\end{array}$ & $\mathrm{RCT}$ & $\begin{array}{l}120 \mathrm{mg} \\
180 \mathrm{mg} \\
240 \mathrm{mg}\end{array}$ & $\begin{array}{l}52 \\
\text { weeks }\end{array}$ & $21 / 22$ & $\begin{array}{l}\text { TSS } \downarrow \text {, } \\
\text { paresthesia } \downarrow \text {, } \\
\text { burning } \\
\text { sensation } \downarrow\end{array}$ & $\begin{array}{l}\text { Transient abnormal liver and } \\
\text { kidney function or } \\
\text { gastrointestinal symptoms }\end{array}$ & $\begin{array}{l}\text { Not } \\
\text { mentioned }\end{array}$ & $\begin{array}{l}\text { (Lou et al., } \\
\text { 2018) }\end{array}$ \\
\hline Scar & Centella cream & $\mathrm{RCT}$ & Unknown & $\begin{array}{l}12 \\
\text { weeks }\end{array}$ & $30 / 30$ & $\begin{array}{l}\text { Vancouver } \\
\text { scores } \uparrow \text {, } \\
\text { pigmentation } \downarrow\end{array}$ & Allergic dermatitis & $\begin{array}{l}\text { Not } \\
\text { mentioned }\end{array}$ & $\begin{array}{l}\text { (Jenwitheesuk } \\
\text { et al., 2018) }\end{array}$ \\
\hline- & $\begin{array}{l}\text { Cosmetic } \\
\text { formulations of } \\
\text { Centella asiatica } \\
\text { extract }\end{array}$ & - & Unknown & 4 weeks & $25 / 0$ & $\begin{array}{l}\text { Skin moisture } \uparrow \text {, } \\
\text { TEWL } \downarrow \text {, skin } \\
\text { redness } \downarrow\end{array}$ & Not mentioned & $\begin{array}{l}\text { Not } \\
\text { mentioned }\end{array}$ & $\begin{array}{l}\text { (Ratz-Lyko } \\
\text { et al., 2016) }\end{array}$ \\
\hline
\end{tabular}

RCT, Randomized controlled trial; TSS, total symptom score; TEWL, transepidermal water loss. 
and $500 \mathrm{mg}$ are safe for patients, and reported just mild to moderate adverse events. The pharmacokinetics of the human studies are inconsistent with animal studies. The main manifestation is that there is $\beta$-glycosidase in the human intestine, which can hydrolyze glycosides, while the animal's $\beta$ glycosidase cannot hydrolyze these glycosides. Because asiaticoside and madecassoside are glycosides, they cannot be easily absorbed by the gastrointestinal tract. Therefore, they are hydrolyzed into asiatic acid and madecassic acid by $\beta$-glycosidase, then these aglycones exert biological functions. The plasma concentrationtime curve reflects that asiaticoside and madecassoside reach Tmax within 1-2 $\mathrm{h}$ after oral administration, while their metabolites asiatic acid and madecassic acid reach Tmax within $3 \mathrm{~h}$, and accompanied by downward trend of parent compound (Songvut et al., 2019). Madecassoside was considered to be a substrate of efflux transporters, which may influence the drug absorption in the gastrointestinal tract. In another study, linked-rat models showed that enterohepatic circulation participates in the absorption and utilization of madecassoside (Leng et al., 2013; Anukunwithaya et al., 2017). A randomized, controlled, double-blind clinical trial found that $C$. asiatica have the potential to reduce diabetic neuropathy. Patients were administered capsules containing $C$. asiatica selected triterpenes for 52 weeks, a significant reduction was observed in their total symptom score (TSS). However, almost $67 \%$ of the patients in the treatment group experienced at least one adverse event, including transient liver, kidney or gastrointestinal dysfunction, but these symptoms resolved on their own (Lou et al., 2018). Another randomized controlled double-blind trial found that C. asiatica cream containing 5.12\% asiaticoside and 5.1\% madecassoside can be completely absorbed by the skin and effectively improve pigmentation and may be used in treating hypertrophic scars (Jenwitheesuk et al., 2018). In a 4-week study of a group of 25 volunteers, a cosmetic formula containing the $C$. asiatica extract was applied on the forearm twice a day, which were prepared into emulsion and hydrogel preparations containing 2.5 and 5\% C. asiatica extract respectively. Revealing that this formula increased the hydration status of skin surface, reduced epidermal water loss, and exerted an anti-inflammatory effect. In addition, the hydration and epidermal barrier function of the subjects in emulsion formulation group was better than that of hydrogel formulation group. Therefore, C. asiatica can be used in moisturizing cosmetic formulations (Ratz-Lyko et al., 2016). Clinical studies also confirmed the effect of $C$. asiatica against generalized anxiety disorder, but the level of evidence was low and the number of patients was rather small (Jana et al., 2010). In addition, a 21-day prospective randomized control study found that $C$. asiatica extract can effectively promote wound healing in diabetic patients without any serious side effects (Paocharoen, 2010). Above all, clinical trials have found that C. asiatica can improve cognitive function, relieve anxiety, promote wound healing, and has effect for skin care, but these effects require more clinical studies with higher levels of evidence need to be performed urgently to validate the findings.

\section{Safety and Toxicity of C. asiatica}

As for the safety of $C$. asiatica extract, clinical trials have shown that $250 \mathrm{mg}$ and $500 \mathrm{mg}$ of standard extract were well tolerated in single and multiple oral doses. Modern pharmacological tests showed that the interaction potential of $C$. asiatica biologically active compounds with CYP isoenzymes is negligible, and the heavy metal content in the extract is within the allowable range (Kar et al., 2017). Animal experiments have found that C. asiatica extract has anti-spermogenic and anti-fertility effects on the reproductive system of male rats (Yunianto et al., 2010). Hematological parameters and histopathology in acute oral toxicity study, sub-chronic toxicity study and mutagenicity study have confirmed that $C$. asiatica extract is safe in rats. Also, C. asiatica extract did not show any dose-related adverse effects in Ames test (Deshpande et al., 2015). However, there are case reports that three women developed jaundice after taking $C$. asiatica for 30, 20, and 60 days, they were clinically diagnosed with granulomatous hepatitis, and their symptoms improved after the drug was stopped (Jorge and Jorge, 2005). About the triterpenoids of $C$. asiatica, the previous clinical trials have showed that emulsions and capsules, which contain several major triterpenoids have different degrees of side effects for patients, but they all relieve without any medical interventions. Although pre-clinical studies of $C$. asiatica have found that it has a wide range of pharmacological effects and demonstrated the safety of it, but considering the bad reports in few clinical cases, rigorous research is recommended for the exploration of clinical dosages with highest safety.

\section{CONCLUSIONS AND PERSPECTIVES}

C. asiatica is an herb used in traditional Chinese medicine. Its main effective components are asiaticoside, asiatic acid, madecassoside, and madecassic acid. As mentioned earlier, $C$. asiatica and its triterpenoids have a wide range of medicinal values. In vivo and in vitro studies showed that $C$. asiatica and its triterpenoids had therapeutic and relieving effects on multisystem diseases. The $C$. asiatica extract effectively relieves sleep deprivation, $\mathrm{AD}$, type 2 diabetes mellitus (T2DM), hyperlipidemia, gestational diabetes, baldness, atopic dermatitis, wound, druginduced liver toxicity, liver injury, gastric mucosal injury, gastric ulcers, breast cancer, leukemia, oral submucous fibrosis, migraine, and so forth. Asiatic acid effectively relieves cognitive impairment, Alzheimer's disease, Parkinson 's disease, obesity, renovascular hypertension, transverse aortic constriction, myocardial ischemia/ reperfusion (MI/R) injury, atherosclerosis, liver fibrosis, acute pancreatitis, colon carcinogenesis, hepatocellular carcinoma, pulmonary fibrosis, lung cancer, pelvic inflammatory, ovarian cancer, endometriosis, sepsis, periodontitis, and so forth. The preclinical studies on asiaticoside found that it has therapeutic potential for the following diseases: hemiparkinsonism, Alzheimer's disease, cerebral ischemia, skin wound, pulmonary hypertension, atherogenesis, ALI, osteolytic bone diseases, and so forth. Pharmacological studies found that madecassoside had potential therapeutic effect against osteoporosis, acne, vitiligo, RA, and so forth. Madecassic acid had a positive therapeutic effect on ischemic retinopathies. The preclinical study on Centella asiatica mainly focused on the extract of $C$. asiatica and asiatic acid. For diseases, neurological and skin diseases are mostly investigated. 


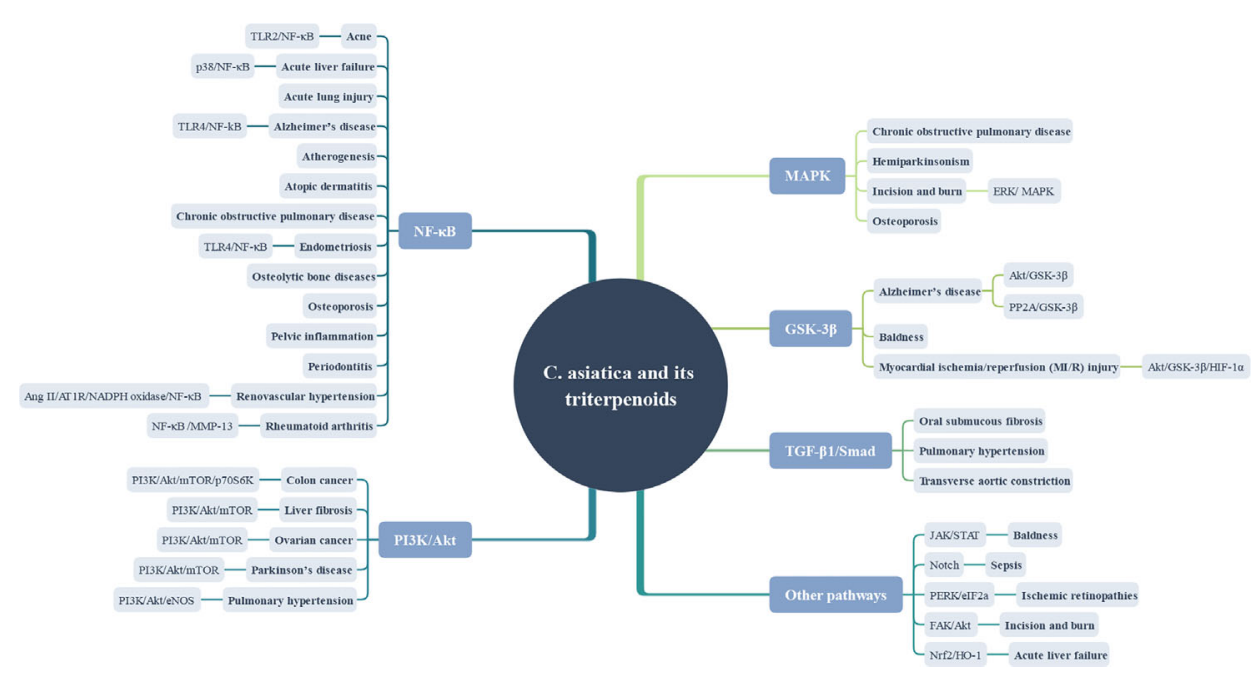

FIGURE 3 | Therapeutic potential and mechanisms of action of $C$. asiatica and its triterpenes.

However, the impact on other diseases also needs further indepth exploration.

The occurrence of inflammatory response, oxidative stress, apoptosis, and mitochondrial dysfunction is closely related to various diseases. C. asiatica and its triterpenoids can be used in many medical situations because they have anti-inflammatory and anti-apoptotic effects, relieve oxidant stress, and improve mitochondrial function (Figure 3). Thus further, C. asiatica may also be applied to diseases not mentioned in this study via the same pathological mechanism, and this hypothesis needs indepth investigation for verification.

Last but not least, this study summarized the in vitro and in vivo studies on C. asiatica and its triterpenoids and listed the significant changes in factors for each disease, providing a reference for subsequent studies. However, only four clinical studies were included, the level of clinical evidence was weak, and more clinical trial supplements were needed. More importantly, the pharmacokinetics of this TCM needs further improvement. Also, the toxic and side effects of the drug, the effective therapeutic dose, and the standardization of the agent still need to be explored. The pharmacological effects of C. asiatica should be explored in detail to provide more rigorous data support for future clinical applications.

\section{REFERENCES}

Adtani, P. N., Narasimhan, M., Punnoose, A. M., and Kambalachenu, H. R. (2017). Antifibrotic effect of Centella asiatica Linn and asiatic acid on arecoline-induced fibrosis in human buccal fibroblasts. J. Invest. Clin. Dent. 8 (2), 1-9. doi: 10.1111/jicd.12208

Ahmad Rather, M., Justin-Thenmozhi, A., Manivasagam, T., Saravanababu, C., Guillemin, G. J., and Essa, M. M. (2019). Asiatic Acid Attenuated Aluminum Chloride-Induced Tau Pathology, Oxidative Stress and Apoptosis Via AKT/ GSK-3 $\beta$ Signaling Pathway in Wistar Rats. Neurotox. Res. 35 (4), 955-968. doi: 10.1007/s12640-019-9999-2

Alasmari, F., Alshammari, M. A., Alasmari, A. F., Alanazi, W. A., and Alhazzani, K. (2018). Neuroinflammatory Cytokines Induce Amyloid Beta Neurotoxicity

\section{AUTHOR CONTRIBUTIONS}

BS and LW designed the study. BS, LW, YW, MH, and MK reviewed the relevant literature and wrote the manuscript. CZ, YW, LQ, and LW contributed to the scientific writing of the manuscript. BS, MG, and TL revised the manuscript. All authors contributed to the article and approved the submitted version. BS, LW, YW, CZ, LQ, MH, MK, MG, and TL contributed equally to this study. BS, LW and YW contributed equally to this study and share first authorship.

\section{FUNDING}

This paper was supported by the International Cooperation Base for the Prevention and Treatment of Chronic Diseases by Traditional Chinese Medicine. No. GZYYGJ2019034.

\section{SUPPLEMENTARY MATERIAL}

The Supplementary Material for this article can be found online at: https://www.frontiersin.org/articles/10.3389/fphar.2020. 568032/full\#supplementary-material

through Modulating Amyloid Precursor Protein Levels/Metabolism. BioMed. Res. Int. 2018, 3087475. doi: 10.1155/2018/3087475

Anastasiadi, Z., Lianos, G. D., Ignatiadou, E., Harissis, H. V., and Mitsis, M. (2017). Breast cancer in young women: an overview. Updates Surg. 69 (3), 313317. doi: 10.1007/s13304-017-0424-1

Anukunwithaya, T., Tantisira, M. H., Tantisira, B., and Khemawoot, P. (2017). Pharmacokinetics of a Standardized Extract of Centella asiatica ECa 233 in Rats. Planta Med. 83 (8), 710-717. doi: 10.1055/s-0042-122344

Ar Rochmah, M., Harini, I. M., Septyaningtrias, D. E., Sari, D. C. R., and Susilowati, R. (2019). Centella asiatica Prevents Increase of Hippocampal Tumor Necrosis Factor- $\alpha$ Independently of Its Effect on Brain-Derived Neurotrophic Factor in Rat Model of Chronic Stress. BioMed. Res. Int. 2019, 2649281. doi: 10.1155/2019/2649281 
Arora, R., Kumar, R., Agarwal, A., Reeta, K. H., and Gupta, Y. K. (2018). Comparison of three different extracts of Centella asiatica for anti-amnesic, antioxidant and anticholinergic activities: in vitro and in vivo study. Biomed. Pharmacother. 105, 1344-1352. doi: 10.1016/j.biopha.2018.05.156

Audebert, A. (2018). "Endometriosis," in Encyclopedia of Endocrine Diseases. Eds. I. Huhtaniemi and L. Martini, 498-505. doi: 10.1016/B978-0-12-801238-3.95837-9

Avena-Woods, C. (2017). Overview of atopic dermatitis. Am. J. Managed Care. 23 (8 Suppl), S115-S123. doi: 10.5415/apallergy.2013.3.2.79

Barbosa, C. C., Rodrigues, T. C., Ataídes, C. F. S., Santos, M. L., Ghedini, P. C., Dias Junior, W., et al. (2019). Protective effects of Hydrocotyle umbellata var. bonariensis Lam. (Araliaceae) on memory in sleep-impaired female mice. J. Ethnopharmacol. 245, 112183. doi: 10.1016/j.jep.2019.112183

Belcaro, G., Ippolito, E., Dugall, M., Hosoi, M., Cornelli, U., Ledda, A., et al. (2015). Pycnogenol(R) and Centella asiatica in the management of asymptomatic atherosclerosis progression. [Journal Article; Observational Study]. Int. Angiol 34 (2), 150-157

Belcaro, G., Dugall, M., Ippolito, E., Hosoi, M., Cornelli, U., Ledda, A., et al. (2017). Pycnogenol(R) and Centella asiatica to prevent asymptomatic atherosclerosis progression in clinical events. Minerva Cardioangiol. 65 (1), 24-31. doi: 10.23736/S0026-4725.16.04008-1

Bina, F., Soleymani, S., Toliat, T., Hajimahmoodi, M., Tabarrai, M., Abdollahi, M., et al. (2019). Plant-derived medicines for treatment of endometriosis: A comprehensive review of molecular mechanisms. Pharmacol. Res. 76-90. doi: 10.1016/j.phrs.2018.11.008

Binti Mohd Yusuf Yeo, N. A., Muthuraju, S., Wong, J. H., Mohammed, F. R., Senik, M. H., Zhang, J., et al. (2018). Hippocampal amino-3-hydroxy-5methyl-4-isoxazolepropionic acid GluA1 (AMPA GluA1) receptor subunit involves in learning and memory improvement following treatment with Centella asiatica extract in adolescent rats. Brain Behav. 8 (9), 1-14. doi: 10.1002/brb3.1093

Blanco, M. D. M. P., Gonzalez, C. R., Saha, A. K., Martins, L., Dieguez, C., VidalPuig, A., et al. (2011). Hypothalamic AMP-activated protein kinase as a mediator of whole body energy balance. [Journal Article; Research Support, Non-U.S. Gov't; Review]. Rev. Endocr. Metab. Disord. 12 (3), 127-140. doi: 10.1007/ s11154-011-9165-5

Bobade, V., Bodhankar, S. L., Aswar, U., Vishwaraman, M., and Thakurdesai, P. (2015). Prophylactic effects of asiaticoside-based standardized extract of Centella asiatica (L.) Urban leaves on experimental migraine: Involvement of 5HT1A/1B receptors. Chin. J. Natural Medicines 13 (4), 274-282. doi: 10.1016/ S1875-5364(15)30014-5

Boondam, Y., Songvut, P., Tantisira, M. H., Tapechum, S., Tilokskulchai, K., and Pakaprot, N. (2019). Inverted U-shaped response of a standardized extract of Centella asiatica (ECa 233) on memory enhancement. Sci. Rep. 9 (1), 1-11. doi: 10.1038/s41598-019-44867-z

Bugg, C. W., and Taira, T. (2016). Pelvic Inflammatory Disease: Diagnosis And Treatment In The Emergency Department. Emergency Med. Pract. 18 (12), 1-24.

Camacho-Alonso, F., Torralba-Ruiz, M. R., García-Carrillo, N., Lacal-Luján, J., Martínez-Díaz, F., and Sánchez-Siles, M. (2019). Effects of topical applications of porcine acellular urinary bladder matrix and Centella asiatica extract on oral wound healing in a rat model. Clin. Oral. Investig. 23 (5), 2083-2095. doi: 10.1007/s00784-018-2620-x

Campana, L., and Iredale, J. P. (2017). Regression of Liver Fibrosis. Semin. Liver Dis. 37 (1), 1-10. doi: 10.1055/s-0036-1597816

Cao, S., Wang, W., Nan, F., Liu, Y., Wei, S., Li, F., et al. (2018). Asiatic acid inhibits LPS-induced inflammatory response in endometrial epithelial cells. Microbial. Pathogenesis 116, 195-199. doi: 10.1016/j.micpath.2018.01.022

Caviedes, A., Lafourcade, C., Soto, C., and Wyneken, U. (2017). BDNF/NF-кB Signaling in the Neurobiology of Depression. Curr. Pharm. Des. 23 (21), 31543163. doi: 10.2174/1381612823666170111141915

Chaisawang, P., Sirichoat, A., Chaijaroonkhanarak, W., Pannangrong, W., Sripanidkulchai, B., Wigmore, P., et al. (2017). Asiatic acid protects against cognitive deficits and reductions in cell proliferation and survival in the rat hippocampus caused by 5-fluorouracil chemotherapy. PLoS One 12 (7), 1-14. doi: 10.1371/journal.pone.0180650

Chanana, P., and Kumar, A. (2016). Possible Involvement of Nitric Oxide Modulatory Mechanisms in the Neuroprotective Effect of Centella asiatica Against Sleep Deprivation Induced Anxiety Like Behaviour, Oxidative Damage and Neuroinflammation. Phytother. Res. 30 (4), 671-680. doi: 10.1002/ptr.5582
Chen, C. L., Tsai, W. H., Chen, C. J., and Pan, T. M. (2016). Centella asiatica extract protects against amyloid $\beta 1-40$-induced neurotoxicity in neuronal cells by activating the antioxidative defence system. J. Tradit. Complement. Med. 6 (4), 362-369. doi: 10.1016/j.jtcme.2015.07.002

Chen, L., Liu, P., Feng, X., and Ma, C. (2017). Salidroside suppressing LPS-induced myocardial injury by inhibiting ROS-mediated PI3K/Akt/mTOR pathway in vitro and in vivo. J. Cell. Mol. Med. 21 (12), 3178-3189. doi: 10.1111/jcmm.12871

Chen, Y., Zheng, X., Wang, Y., and Song, J. (2018). Effect of PI3K/Akt/mTOR signaling pathway on JNK3 in Parkinsonian rats. Exp. Ther. Med. 17 (3), 17711775. doi: 10.3892/etm.2018.7120

Chen, Z., Chen, S., and Liu, J. (2018). The role of T cells in the pathogenesis of Parkinson's disease. Prog. Neurobiol. 169, 1-23. doi: 10.1016/j.pneurobio.2018.08.002

Chen, H., Luo, J., and Guo, J. (2020). Development and validation of a fiveimmune gene prognostic risk model in colon cancer. BMC Cancer 20 (1), 395. doi: 10.1186/s12885-020-06799-0

Cheng, Q., Liao, M., Hu, H., Li, H., and Wu, L. (2018). Asiatic Acid (AA) Sensitizes Multidrug-Resistant Human Lung Adenocarcinoma A549/DDP Cells to Cisplatin (DDP) via Downregulation of P-Glycoprotein (MDR1) and Its Targets. Cell. Physiol. Biochem. 47 (1), 279-292. doi: 10.1159/000489806

Chintapanti, S., Pratap Reddy, K., and Sreenivasula Reddy, P. (2018). Behavioral and neurochemical consequences of perinatal exposure to lead in adult male Wistar rats: protective effect by Centella asiatica. Environ. Sci. Pollut. Res. 25 (13), 13173-13185. doi: 10.1007/s11356-018-1500-x

Chiroma, S. M., Baharuldin, M. T. H., Taib, C. N. M., Amom, Z., Jagadeesan, S., Adenan, M.II, et al. (2019a). Centella asiatica protects D-galactose/ $\mathrm{AlCl} 3$ mediated alzheimer's disease-like rats via PP2A/GSK-3 $\beta$ signaling pathway in their hippocampus. Int. J. Mol. Sci. 20 (8). doi: 10.3390/ijms20081871

Chiroma, S. M., Hidayat Baharuldin, M. T., Mat Taib, C. N., Amom, Z., Jagadeesan, S., Adenan, M.II, et al. (2019b). Protective effect of Centella asiatica against D -galactose and aluminium chloride induced rats: Behavioral and ultrastructural approaches. Biomed. Pharmacother. 109, 853864. doi: 10.1016/j.biopha.2018.10.111

Choi, M. J., Zheng, H. M., Kim, J. M., Lee, K. W., Park, Y. H., and Lee, D. H. (2016) Protective effects of Centella asiatica leaf extract on dimethylnitrosamine-induced liver injury in rats. Mol. Med. Rep. 14 (5), 4521-4528. doi: 10.3892/mmr.2016.5809

Choi, Y. M., An, S., Lee, J., Lee, J. H., Lee, J. N., Kim, Y. S., et al. (2017). Titrated extract of Centella asiatica increases hair inductive property through inhibition of STAT signaling pathway in three-dimensional spheroid cultured human dermal papilla cells. Biosci. Biotechnol. Biochem. 81 (12), 2323-2329. doi: 10.1080/09168451.2017.1385383

Collins, K. H., Herzog, W., MacDonald, G. Z., Reimer, R. A., Rios, J. L., Smith, I. C., et al. (2018). Obesity, metabolic syndrome, and musculoskeletal disease: Common inflammatory pathways suggest a central role for loss of muscle integrity. Front. Physiol. 112-112. doi: 10.3389/fphys.2018.00112

Cui, Q., Ren, J., Zhou, Q., Yang, Q., and Li, B. (2019). Effect of asiatic acid on epithelial-mesenchymal transition of human alveolar epithelium A549 cells induced by TGF- $\beta 1$. Oncol. Lett. 17 (5), 4285-4292. doi: 10.3892/ol.2019.10140

Dai, Y., Wang, Z., Quan, M., Lv, Y., Li, Y., Xin, H. B., et al. (2018). Asiatic acid protests against myocardial ischemia/reperfusion injury via modulation of glycometabolism in rat cardiomyocyte. Drug Des. Dev. Ther. 12, 3573-3582. doi: $10.2147 / D D D T . S 175116$

David Boothe, W., Tarbox, J. A., and Tarbox, M. B. (2017). Atopic Dermatitis: Pathophysiology. Adv. Exp. Med. Biol. 1027, 21-37. doi: 10.1007/978-3-31964804-0_3

de Boer, R. A., De Keulenaer, G., Bauersachs, J., Brutsaert, D., Cleland, J. G., Diez, J., et al. (2019). Towards better definition, quantification and treatment of fibrosis in heart failure. A scientific roadmap by the Committee of Translational Research of the Heart Failure Association (HFA) of the European Society of Cardiology. In Eur. J. Heart Failure 21 (3), 272-285. doi: 10.1002/ejhf.1406

De Sanctis, M. T., Belcaro, G., Incandela, L., Cesarone, M. R., Griffin, M., Ippolito, E., et al. (2001). Treatment of edema and increased capillary filtration in venous hypertension with total triterpenic fraction of Centella asiatica: a clinical, prospective, placebo-controlled, randomized, dose-ranging trial. [Clinical Trial; Journal Article; Randomized Controlled Trial]. Angiology 52 (Suppl 2), S55-S59.

Delgado-Wicke, P., Rodríguez-Luna, A., Ikeyama, Y., Honma, Y., Kume, T., Gutierrez, M., et al. (2020). Fernblock ${ }^{\circledR}$ Upregulates NRF2 Antioxidant Pathway and Protects Keratinocytes from PM2.5-Induced Xenotoxic Stress. Oxid. Med. Cell. Longevity. 2020, 2908108. doi: 10.1155/2020/2908108 
Delitala, A. P., Scuteri, A., and Doria, C. (2020). Thyroid Hormone Diseases and Osteoporosis. [Journal Article; Review]. J. Clin. Med. 9 (4), 1034. doi: 10.3390/ jcm9041034

Deshpande, P. O., Mohan, V., and Thakurdesai, P. (2015). Preclinical Safety Assessment of Standardized Extract of Centella asiatica (L.) Urban Leaves . [Journal Article]. Toxicol. Int. 22 (1), 10-20. doi: 10.4103/0971-6580.172251

Di Tomo, P., Di Silvestre, S., Cordone, V. G. P., Giardinelli, A., Faricelli, B., Pipino, C., et al. (2015). Centella Asiatica and Lipoic Acid, or a combination thereof, inhibit monocyte adhesion to endothelial cells from umbilical cords ofgestational diabetic women. Nutr. Metab. Cardiovasc. Dis. 25 (7), 659-666. doi: $10.1016 /$ j.numecd.2015.04.002

Dolan, E., Swinton, P. A., Sale, C., Healy, A., and O'Reilly, J. (2017). Influence of adipose tissue mass on bone mass in an overweight or obese population: systematic review and meta-analysis. Nutr. Rev. 75 (10), 858-870. doi: 10.1093/ nutrit/nux046

Dong, S. H., Liu, Y. W., Wei, F., Tan, H. Z., and Han, Z. D. (2017). Asiatic acid ameliorates pulmonary fibrosis induced by bleomycin (BLM) via suppressing pro-fibrotic and inflammatory signaling pathways. Biomed. Pharmacother. 89 , 1297-1309. doi: 10.1016/j.biopha.2017.03.005

Döring, Y., Noels, H., van der Vorst, E. P. C., Neideck, C., Egea, V., Drechsler, M., et al. (2017). Vascular CXCR4 Limits Atherosclerosis by Maintaining Arterial Integrity: Evidence From Mouse and Human Studies. Circulation 136 (4), 388403. doi: 10.1161/CIRCULATIONAHA.117.027646

Falcone, T., and Flyckt-Rebecca, R. (2018). Clinical management of endometriosis. Obstet. Gynecol. 131 (3), 557-571. doi: 10.1097/AOG.0000000000002469

Fard, S. E., Tafvizi, F., and Torbati, M. B. (2018). Silver nanoparticles biosynthesised using Centella asiatica leaf extract: Apoptosis induction in MCF-7 breast cancer cell line. IET Nanobiotechnol. 12 (7), 994-1002. doi: 10.1049 /iet-nbt.2018.5069

Farhana, K. M., Malueka, R. G., Wibowo, S., and Gofir, A. (2016). Effectiveness of Gotu Kola Extract $750 \mathrm{mg}$ and $1000 \mathrm{mg}$ Compared with Folic Acid $3 \mathrm{mg}$ in Improving Vascular Cognitive Impairment after Stroke. Evidence-Based Complement. Altern. Med. 2016, 2795915. doi: 10.1155/2016/2795915

Feng, X., Huang, D., Lin, D., Zhu, L., Zhang, M., Chen, Y., et al. (2019). Effects of Asiaticoside Treatment on the Survival of Random Skin Flaps in Rats. J. Invest. Surg., 1-11. doi: 10.1080/08941939.2019.1584255

Fitri, A. R., Pavasant, P., Chamni, S., and Sumrejkanchanakij, P. (2018). Asiaticoside induces osteogenic differentiation of human periodontal ligament cells through the Wnt pathway. J. Periodontol. 89 (5), 596-605. doi: 10.1002/JPER.17-0471

Fong, L. Y., Ng, C. T., Zakaria, Z. A., Baharuldin, M. T. H., Arifah, A. K., Hakim, M. N., et al. (2015). Asiaticoside inhibits TNF- $\alpha$-induced endothelial hyperpermeability of human aortic endothelial cells. Phytother. Res. 29 (10), 1501-1508. doi: 10.1002/ptr.5404

Fong, L. Y., Ng, C. T., Cheok, Z. L., Mohd Moklas, M. A., Hakim, M. N., and Ahmad, Z. (2016). Barrier protective effect of asiatic acid in TNF- $\alpha$-induced activation of human aortic endothelial cells. Phytomedicine 23 (2), 191-199. doi: 10.1016/j.phymed.2015.11.019

Fong, L. Y., Ng, C. T., Yong, Y. K., Hakim, M. N., and Ahmad, Z. (2019). Asiatic acid stabilizes cytoskeletal proteins and prevents TNF- $\alpha$-induced disorganization of cell-cell junctions in human aortic endothelial cells. Vasc. Pharmacol. 117, 15-26. doi: 10.1016/j.vph.2018.08.005

Gelders, G., Baekelandt, V., and Van der Perren, A. (2018). Linking neuroinflammation and neurodegeneration in parkinson's disease. In J. Immunol. Res. 2018, 4784268. doi: 10.1155/2018/4784268

Ghosh, K., Indra, N., and Jagadeesan, G. (2017). The ameliorating effect of Centella asiatica ethanolic extract on albino rats treated with isoniazid. J. Basic Clin. Physiol. Pharmacol. 28 (1), 67-77. doi: 10.1515/jbcpp-2016-0059

Glassman, S. J. (2011). Vitiligo, reactive oxygen species and T-cells. Clin. Sci. (Lond). 120 (3), 99-120. doi: 10.1042/CS20090603

Gopi, M., and Arambakkam Janardhanam, V. (2017). Asiaticoside: Attenuation of rotenone induced oxidative burden in a rat model of hemiparkinsonism by maintaining the phosphoinositide-mediated synaptic integrity. Pharmacol. Biochem. Behav. 155, 1-15. doi: 10.1016/j.pbb.2017.02.005

Grandhi, M. S., Kim, A. K., Ronnekleiv-Kelly, S. M., Kamel, I. R., Ghasebeh, M. A., and Pawlik, T. M. (2016). Hepatocellular carcinoma: From diagnosis to treatment. Surg. Oncol. 25 (2), 74-85. doi: 10.1016/j.suronc.2016.03.002
Gray, N. E., Sampath, H., Zweig, J. A., Quinn, J. F., and Soumyanath, A. (2015). Centella asiatica Attenuates Amyloid- $\beta$-Induced Oxidative Stress and Mitochondrial Dysfunction. J. Alzheimer's Dis. 45 (3), 933-946. doi: 10.3233/ JAD-142217

Gray, N. E., Harris, C. J., Quinn, J. F., and Soumyanath, A. (2016). Centella asiatica modulates antioxidant and mitochondrial pathways and improves cognitive function in mice. J. Ethnopharmacol. 180, 78-86. doi: 10.1016/j.jep.2016.01.013

Gray, N. E., Zweig, J. A., Matthews, D. G., Caruso, M., Quinn, J. F., and Soumyanath, A. (2017a). Centella asiatica Attenuates Mitochondrial Dysfunction and Oxidative Stress in A $\beta$-Exposed Hippocampal Neurons. Oxid. Med. Cell. Longevity 2017, 7023091. doi: 10.1155/2017/7023091

Gray, N. E., Zweig, J. A., Murchison, C., Caruso, M., Matthews, D. G., Kawamoto, C., et al. (2017b). Centella asiatica attenuates $A \beta$-induced neurodegenerative spine loss and dendritic simplification. Neurosci. Lett. 646, 24-29. doi: 10.1016/ j.neulet.2017.02.072

Gray, N. E., Zweig, J. A., Caruso, M., Martin, M. D., Zhu, J. Y., Quinn, J. F., et al. (2018a). Centella asiatica increases hippocampal synaptic density and improves memory and executive function in aged mice. Brain Behav. 8 (7), 1-11. doi: 10.1002/brb3.1024

Gray, N. E., Zweig, J. A., Caruso, M., Zhu, J. Y., Wright, K. M., Quinn, J. F., et al. (2018b). Centella asiatica attenuates hippocampal mitochondrial dysfunction and improves memory and executive function in $\beta$-amyloid overexpressing mice. Mol. Cell. Neurosci. 93, 1-9. doi: 10.1016/j.mcn.2018.09.002

Halpern, C. H., Wolf, J. A., Bale, T. L., Stunkard, A. J., Danish, S. F., Grossman, M., et al. (2008). Deep brain stimulation in the treatment of obesity. [Journal Article; Review]. J. Neurosurg. 109 (4), 625-634. doi: 10.3171/JNS/2008/109/10/0625

Hao, C., Wu, B., Hou, Z., Xie, Q., Liao, T., Wang, T., et al. (2017). Asiatic acid inhibits LPS-induced inflammatory response in human gingival fibroblasts. Int. Immunopharmacol. 50, 313-318. doi: 10.1016/j.intimp.2017.07.005

Hao, Y., Huang, J., Ma, Y., Chen, W., Fan, Q., Sun, X., et al. (2018). Asiatic acid inhibits proliferation, migration and induces apoptosis by regulating Pdcd 4 via the PI3K/Akt/mTOR/p70S6K signaling pathway in human colon carcinoma cells. Oncol. Lett. 15 (6), 8223-8230. doi: 10.3892/ol.2018.8417

He, L., Hong, G., Zhou, L., Zhang, J., Fang, J., He, W., et al. (2019). Asiaticoside, a component of Centella asiatica attenuates RANKL-induced osteoclastogenesis via NFATc1 and NF-KB signaling pathways. J. Cell. Physiol. 234 (4), 42674276. doi: $10.1002 /$ jcp. 27195

Hirsch, F. R., Scagliotti, G. V., Mulshine, J. L., Kwon, R., Curran, W. J., Wu, Y. L., et al. (2017). Lung cancer: current therapies and new targeted treatments. In Lancet. 389 (10066), 299-311. doi: 10.1016/S0140-6736(16)30958-8

Hu, H. H., Chen, D. Q., Wang, Y. N., Feng, Y. L., Cao, G., and Vaziri, N. D. (2018). New insights into TGF- $\beta /$ Smad signaling in tissue fibrosis. Chem. Biol. Interact. 292, 76-83. doi: 10.1016/j.cbi.2018.07.008

Huang, X., Zuo, L., Lv, Y., Chen, C., Yang, Y., Xin, H., et al. (2016). Asiatic acid attenuates myocardial ischemia/reperfusion injury via Akt/GSK-3 $3 / \mathrm{HIF}-1 \alpha$ signaling in rat H9c2 cardiomyocytes. Molecules 21 (9), 1-14. doi: 10.3390/ molecules 21091248

Huang, Q., Cao, H., Zhan, L., Sun, X., Wang, G., Li, J., et al. (2017). Mitochondrial fission forms a positive feedback loop with cytosolic calcium signaling pathway to promote autophagy in hepatocellular carcinoma cells. Cancer Lett. 403, 108118. doi: 10.1016/j.canlet.2017.05.034

Huang, W., Gao, F., Hu, F., Huang, J., Wang, M., Xu, P., et al. (2018). Asiatic acid prevents retinal ganglion cell apoptosis in a rat model of glaucoma. Front. Neurosci. 12, 489. doi: 10.3389/fnins.2018.00489

Intararuchikul, T., Teerapattarakan, N., Rodsiri, R., Tantisira, M., Wohlgemuth, G., Fiehn, O., et al. (2019). Effects of Centella asiatica extract on antioxidant status and liver metabolome of rotenone-treated rats using GC-MS. Biomed. Chromatogr. 33 (2), e4395. doi: 10.1002/bmc.4395

Jaiyeoba, O., Lazenby, G., and Soper, D. E. (2011). Recommendations and rationale for the treatment of pelvic inflammatory disease. Expert Rev. AntiInfective Ther. 9 (1), 61-70. doi: 10.1586/eri.10.156

Jana, U., Sur, T. K., Maity, L. N., Debnath, P. K., and Bhattacharyya, D. (2010). A clinical study on the management of generalized anxiety disorder with Centella asiatica. [Clinical Trial; Journal Article; Research Support, Non-U.S. Gov't]. Nepal Med. Coll. J. 12 (1), 8-11.

Jenwitheesuk, K., Rojsanga, P., Chowchuen, B., and Surakunprapha, P. (2018). A prospective randomized, controlled, double-blind trial of the efficacy using 
centella cream for scar improvement. Evidence-Based Complement. Altern. Med. 2018, 9525624. doi: 10.1155/2018/9525624

Jiang, T., Sun, Q., and Chen, S. (2016). Oxidative stress: A major pathogenesis and potential therapeutic target of antioxidative agents in Parkinson's disease and Alzheimer's disease. Prog. Neurobiol. 147, 1-19. doi: 10.1016/j.pneurobio. 2016.07.005

Jing, L., Haitao, W., Qiong, W., Fu, Z., Nan, Z., and Xuezheng, Z. (2018). Anti inflammatory effect of asiaticoside on human umbilical vein endothelial cells induced by ox-LDL. Cytotechnology 70 (2), 855-864. doi: 10.1007/s10616-0180198-4

Jorge, O. A., and Jorge, A. D. (2005). Hepatotoxicity associated with the ingestion of Centella asiatica. . [Case Reports; Journal Article]. Rev. Esp Enferm. Dig. 97 (2), 115-124. doi: 10.4321/s1130-01082005000200006

Ju Ho, P., Jun Sung, J., Ki Cheon, K., and Jin Tae, H. (2018). Anti-inflammatory effect of Centella asiatica phytosome in a mouse model of phthalic anhydrideinduced atopic dermatitis. Phytomedicine 43, 110-119. doi: 10.1016/ j.phymed.2018.04.013

Kamble, S. M., and Patil, C. R. (2018). Asiatic Acid Ameliorates DoxorubicinInduced Cardiac and Hepato-Renal Toxicities with Nrf2 Transcriptional Factor Activation in Rats. Cardiovasc. Toxicol. 18 (2), 131-141. doi: 10.1007/ s12012-017-9424-0

Kar, A., Pandit, S., Mukherjee, K., Bahadur, S., and Mukherjee, P. K. (2017). Safety assessment of selected medicinal food plants used in Ayurveda through CYP450 enzyme inhibition study. [Journal Article]. J. Sci. Food Agric. 97 (1), 333-340. doi: 10.1002/jsfa.7739

Kempuraj, D., Thangavel, R., Selvakumar, G. P., Zaheer, S., Ahmed, M. E., Raikwar, S. P., et al. (2017). Brain and Peripheral Atypical Inflammatory Mediators Potentiate Neuroinflammation and Neurodegeneration. [Journal Article; Review]. Front. Cell Neurosci. 11, 216. doi: 10.3389/fncel.2017.00216

Kircik, L. H. (2016). Advances in the Understanding of the Pathogenesis of Inflammatory Acne. J. Drugs Dermatol. 15 (1 Suppl 1), s7-s10.

Kolb, R., Sutterwala, F. S., and Zhang, W. (2016). Obesity and cancer: inflammation bridges the two. Curr. Opin. Pharmacol. 29, 77-89. doi: 10.1016/j.coph.2016. 07.005

Kong, D., Fu, P., Zhang, Q., Ma, X., and Jiang, P. (2019). Protective effects of Asiatic acid against pelvic inflammatory disease in rats. Exp. Ther. Med. 17 (6), 4687-4692. doi: 10.3892/etm.2019.7498

Konttinen, Y. T., Ainola, M., Vallcala, H., Ma, J., Ida, H., Mandelin, J., et al. (1999). Analysis of 16 different matrix metalloproteinases (MMP-1 to MMP-20) in the synovial membrane: Different profiles in trauma and rheumatoid arthritis. Ann. Rheum. Dis. 58 (11), 691-697. doi: 10.1136/ard.58.11.691

Kumari, S., Deori, M., Elancheran, R., Kotoky, J., and Devi, R. (2016). In vitro and in vivo antioxidant, anti-hyperlipidemic properties and chemical characterization of Centella asiatica (L.) extract. Front. Pharmacol. 7, 400 (OCT). doi: 10.3389/fphar.2016.00400

Kwiecien, S., Konturek, P. C., Sliwowski, Z., Mitis-Musiol, M., Pawlik, M. W., Brzozowski, B., et al. (2012). Interaction between selective cyclooxygenase inhibitors and capsaicin-sensitive afferent sensory nerves in pathogenesis of stress-induced gastric lesions. Role of oxidative stress. J. Physiol. Pharmacol. 63 (2), 143-151.

Lawrence, T. (2009). The nuclear factor NF-kappaB pathway in inflammation. In Cold Spring Harbor Perspect. Biol. 1 (6), a001651. doi: 10.1101/cshperspect. a001651

Lee, J. K., and Kim, N. J. (2017). Recent advances in the inhibition of p38 MAPK as a potential strategy for the treatment of Alzheimer's disease. Molecules. 22 (8), 1287. doi: $10.3390 /$ molecules 22081287

Lee, J. W., Park, H. A., Kwon, O. K., Jang, Y. G., Kim, J. Y., Choi, B. K., et al. (2016). Asiatic acid inhibits pulmonary inflammation induced by cigarette smoke. Int. Immunopharmacol. 39, 208-217. doi: 10.1016/j.intimp.2016.07.010

Leng, D. D., Han, W. J., Rui, Y., Dai, Y., and Xia, Y. F. (2013). In vivo disposition and metabolism of madecassoside, a major bioactive constituent in Centella asiatica (L.) Urb. J. Ethnopharmacol. 150 (2), 601-608. doi: 10.1016/ j.jep.2013.09.004

Li, Q., Yang, J., Zhang, J., Liu, X. W., Yang, C. J., Fan, Z. X., et al. (2020). Inhibition of microRNA-327 ameliorates ischemia/reperfusion injury-induced cardiomyocytes apoptosis through targeting apoptosis repressor with caspase recruitment domain. J. Cell Physiol. 235 (4), 3753-3767. doi: 10.1002/jcp.29270
Lima Giacobbo, B., Doorduin, J., Klein, H. C., Dierckx, R. A. J. O., Bromberg, E., and de Vries, E. F. J. (2019). Brain-Derived Neurotrophic Factor in Brain Disorders: Focus on Neuroinflammation. Mol. Neurobiol. 56 (5), 3295-3312. doi: 10.1007/s12035-018-1283-6

Ling, Y., Gong, Q., Xiong, X., Sun, L., Zhao, W., Zhu, W., et al. (2017). Protective effect of madecassoside on $\mathrm{H} 2 \mathrm{O} 2$-induced oxidative stress and autophagy activation in human melanocytes. Oncotarget 8 (31), 51066-51075. doi: $10.18632 /$ oncotarget.17654

Liu, S. Y., Duan, X. C., Jin, S., Teng, X., Xiao, L., and Xue, H. M. (2017). Hydrogen Sulfide Improves Myocardial Remodeling via Downregulated Angiotensin II/ AT1R Pathway in Renovascular Hypertensive Rats. Am. J. Hypertens. 30 (1), 67-74. doi: 10.1093/ajh/hpw104

Lontchi-Yimagou, E., Sobngwi, E., Matsha, T. E., and Kengne, A. P. (2013). Diabetes mellitus and inflammation. Curr. Diabetes Rep. 13 (3), 435-444. doi: 10.1007/s11892-013-0375-y

Lou, J.-S., Dimitrova, D. M., Murchison, C., Arnold, G. C., Belding, H., Seifer, N., et al. (2018). Centella asiatica triterpenes for diabetic neuropathy: a randomized, double-blind, placebo-controlled, pilot clinical study. Esperienze Dermatologiche 20 (2 Suppl 1), 12-22. doi: 10.23736/S1128-9155.18.00455-7

Lu, Y., Liu, S., Wang, Y., Wang, D., Gao, J., and Zhu, L. (2016). Asiatic acid uncouples respiration in isolated mouse liver mitochondria and induces HepG2 cells death. Eur. J. Pharmacol. 786, 212-223. doi: 10.1016/ j.ejphar.2016.06.010. Elsevier.

Lv, J., Sharma, A., Zhang, T., Wu, Y., and Ding, X. (2018). Pharmacological Review on Asiatic Acid and Its Derivatives: A Potential Compound. [Journal Article; Research Support, Non-U.S. Gov't; Review]. SLAS Technol. 23 (2), 111-127. doi: $10.1177 / 2472630317751840$

Maneesai, P., Bunbupha, S., Kukongviriyapan, U., Senggunprai, L., Kukongviriyapan, V., Prachaney, P., et al. (2017). Effect of asiatic acid on the Ang II-AT1R-NADPH oxidase-NF- $\mathrm{KB}$ pathway in renovascular hypertensive rats. Naunyn-Schmiedeberg's Arch. Pharmacol. 390 (10), 1073-1083. doi: $10.1007 / \mathrm{s} 00210-017-1408-\mathrm{x}$

Marsal, S., and Juliá, A. (2010). Rheumatoid arthritis pharmacogenomics. Pharmacogenomics. 11 (5), 617-619. doi: 10.2217/pgs.10.53

Martinez-Cue, C., and Rueda, N. (2020). Cellular Senescence in Neurodegenerative Diseases. [Journal Article; Review]. Front. Cell Neurosci. 14, 16. doi: 10.3389/ fncel.2020.00016

Masola, B., Oguntibeju, O. O., and Oyenihi, A. B. (2018). Centella asiatica ameliorates diabetes-induced stress in rat tissues via influences on antioxidants and inflammatory cytokines. Biomed. Pharmacother. 101 (October 2017), 447-457. doi: 10.1016/j.biopha.2018.02.115

Matuszkiewicz-Rowińska, J., and Wieliczko, M. (2015). Nadciśnienie naczyniowonerkowe [Renovascular hypertension]. Wiad Lek. 68 (4 Pt 2), 623-625.

Maulidiani, A., Khatib, A., Perumal, V., Suppaiah, V., Ismail, A., Hamid, M., et al. (2016). Metabolic alteration in obese diabetes rats upon treatment with Centella asiatica extract. J. Ethnopharmacol. 180, 60-69. doi: 10.1016/ j.jep.2016.01.001

McVey, M., Tabuchi, A., and Kuebler, W. M. (2012). Microparticles and acute lung injury. Am. J. Physiol. - Lung Cell. Mol. Physiol. 303 (5), L364-L381. doi: 10.1152/ajplung.00354.2011

Mohammadi, A., Amooeian, V. G., and Rashidi, E. (2018). Dysfunction in BrainDerived Neurotrophic Factor Signaling Pathway and Susceptibility to Schizophrenia, Parkinson's and Alzheimer's Diseases. Curr. Gene Ther. 18 (1), 45-63. doi: 10.2174/1566523218666180302163029

Morais, V. A., and De Strooper, B. (2010). Mitochondria dysfunction and neurodegenerative disorders: Cause or consequence. J. Alzheimer's Dis. 20 (Suppl 2), S255-S263. doi: 10.3233/JAD-2010-100345

Murray, M. T., and Pizzorno, J. E. Jr (2012). Textbook of natural medicine. 4th ed. Eds. J. E. Pizzorno Jr. and T. Michael (Edinburgh: Churchill Livingstone), 650.

Nagoor, M. M., Goyal, S. N., Suchal, K., Sharma, C., Patil, C. R., and Ojha, S. K. (2018). Pharmacological Properties, Molecular Mechanisms, and Pharmaceutical Development of Asiatic Acid: A Pentacyclic Triterpenoid of Therapeutic Promise. [Journal Article; Review]. Front. Pharmacol. 9, 892. doi: $10.3389 /$ fphar.2018.00892

Naidoo, D. B., Chuturgoon, A. A., Phulukdaree, A., Guruprasad, K. P., Satyamoorthy, K., and Sewram, V. (2017a). Centella asiatica modulates cancer cachexia associated inflammatory cytokines and cell death in 
leukaemic THP-1 cells and peripheral blood mononuclear cells (PBMC's). BMC Complement. Altern. Med. 17 (1), 1-11. doi: 10.1186/s12906-017-1865-2

Naidoo, D. B., Phulukdaree, A., Anand, K., Sewram, V., and Chuturgoon, A. A. (2017b). Centella asiatica Fraction-3 Suppresses the Nuclear Factor Erythroid 2-Related Factor 2 Anti-Oxidant Pathway and Enhances Reactive Oxygen Species-Mediated Cell Death in Cancerous Lung A549 Cells. J. Med. Food 20 (10), 959-968. doi: 10.1089/jmf.2017.0005

Nataraj, J., Manivasagam, T., Justin Thenmozhi, A., and Essa, M. M. (2017a). Neuroprotective effect of asiatic acid on rotenone-induced mitochondrial dysfunction and oxidative stress-mediated apoptosis in differentiated SH-SYS5Y cells. Nutr. Neurosci. 20 (6), 351-359. doi: 10.1080/1028415X. 2015.1135559

Nataraj, J., Manivasagam, T., Justin Thenmozhi, A., and Essa, M. M. (2017b). Neurotrophic Effect of Asiatic acid, a Triterpene of Centella asiatica Against Chronic 1-Methyl 4-Phenyl 1, 2, 3, 6-Tetrahydropyridine Hydrochloride/ Probenecid Mouse Model of Parkinson's disease: The Role of MAPK, PI3KAkt-GSK3 $\beta$ and mTOR Signalling Pathwa. Neurochem. Res. 42 (5), 1354-1365. doi: 10.1007/s11064-017-2183-2

Nguyen-Lefebvre, A. T., Ajith, A., Portik-Dobos, V., Horuzsko, D. D., Arbab, A. S., Dzutsev, A., et al. (2018). The innate immune receptor TREM-1 promotes liver injury and fibrosis. J. Clin. Investi. 128 (11), 4870-4883. doi: 10.1172/JCI98156

Nie, Y., Sun, L., Wu, Y., Yang, Y., Wang, J., He, H., et al. (2017). AKT2 Regulates Pulmonary Inflammation and Fibrosis via Modulating Macrophage Activation. J. Immunol. 198 (11), 4470-4480. doi: 10.4049/jimmunol.1601503

Oliveira, T. L. S., de Morais, S. R., de Sá, S., de Oliveira, M. G., Florentino, I. F., da Silva, D. M., et al. (2017). Antinociceptive, anti-inflammatory and anxiolyticlike effects of the ethanolic extract, fractions and Hibalactone isolated from Hydrocotyle umbellata L. (Acariçoba) - Araliaceae. Biomed. Pharmacother. 95, 837-846. doi: 10.1016/j.biopha.2017.08.140

Omar, N., Lokanathan, Y., Mohd Razi, Z. R., and Bt Haji Idrus, R. (2019). The effects of Centella asiatica (L.) Urban on neural differentiation of human mesenchymal stem cells in vitro. BMC Complement. Altern. Med. 19 (1), 1-15. doi: 10.1186/s12906-019-2581-x

Onyango, I. G., Khan, S. M., and Bennett, J. P. Jr. (2017). Mitochondria in the pathophysiology of Alzheimer's and Parkinson's diseases. Front. Biosci. (Landmark Ed). 22, 854-872. doi: 10.2741/4521

Ortega, F. B., Lavie, C. J., and Blair, S. N. (2016). Obesity and cardiovascular disease. Circ. Res. 118 (11), 1752-1770. doi: 10.1161/CIRCRESAHA.115.306883

Oyenihi, A. B., Chegou, N. N., Oguntibeju, O. O., and Masola, B. (2017). Centella asiatica enhances hepatic antioxidant status and regulates hepatic inflammatory cytokines in type 2 diabetic rats. Pharm. Biol. 55 (1), 16711678. doi: 10.1080/13880209.2017.1318293

Oyenihi, A. B., Langa, S. O. P., Mukaratirwa, S., and Masola, B. (2019). Effects of Centella asiatica on skeletal muscle structure and key enzymes of glucose and glycogen metabolism in type 2 diabetic rats. Biomed. Pharmacother. 112, 108715. doi: 10.1016/j.biopha.2019.108715

Paocharoen, V. (2010). The efficacy and side effects of oral Centella asiatica extract for wound healing promotion in diabetic wound patients. [Journal Article; Randomized Controlled Trial]. J. Med. Assoc. Thai 93 (Suppl 7), S166-S170.

Park, J. H., Choi, J. Y., Son, D. J., Park, E. K., Song, M. J., Hellström, M., et al. (2017). Anti-inflammatory effect of titrated extract of Centella asiatica in phthalic anhydride-induced allergic dermatitis animal model. Int. J. Mol. Sci. 18 (4), 1-14. doi: 10.3390/ijms18040738

Qi, Z., Ci, X., Huang, J., Liu, Q., Yu, Q., Zhou, J., et al. (2017). Asiatic acid enhances Nrf2 signaling to protect HepG2 cells from oxidative damage through Akt and ERK activation. Biomed. Pharmacother. 88, 252-259. doi: 10.1016/ j.biopha.2017.01.067

Qi, J. J., Li, X. X., Diao, Y. F., Liu, P. L., Wang, D. L., Bai, C. Y., et al. (2020). Asiatic acid supplementation during the in vitro culture period improves early embryonic development of porcine embryos produced by parthenogenetic activation, somatic cell nuclear transfer and in vitro fertilization. Theriogenology 142, 26-33. doi: 10.1016/j.theriogenology.2019.09.027

Qian, Y., Xin, Z., Lv, Y., Wang, Z., Zuo, L., Huang, X., et al. (2018). Asiatic acid suppresses neuroinflammation in BV2 microglia: Via modulation of the Sirt1/ NF-KB signaling pathway. Food Funct. 9 (2), 1048-1057. doi: 10.1039/ c7fo01442b

Qiu, J., Yu, L., Zhang, X., Wu, Q., Wang, D., Wang, X., et al. (2015). Asiaticoside attenuates lipopolysaccharide-induced acute lung injury via down-regulation of NF- $\mathrm{KB}$ signaling pathway. Int. Immunopharmacol. 26 (1), 181-187. doi: 10.1016/j.intimp.2015.03.022

Quaratino, S., Forssmann, U., and Marschner, J. P. (2017). New approaches in immunotherapy for the treatment of lung cancer. Curr. Topics Microbiol. Immunol. 405, 1-31. doi: 10.1007/82_2014_428

Rabe, K. F., and Watz, H. (2017). Chronic obstructive pulmonary disease. Lancet. 389 (10082), 1931-1940. doi: 10.1016/S0140-6736(17)31222-9

Rameshreddy, P., Uddandrao, V. V. S., Brahmanaidu, P., Vadivukkarasi, S., Ravindarnaik, R., Suresh, P., et al. (2018). Obesity-alleviating potential of asiatic acid and its effects on ACC1, UCP2, and CPT1 mRNA expression in high fat diet-induced obese Sprague-Dawley rats. Mol. Cell. Biochem. 442 (12), 143-154. doi: 10.1007/s11010-017-3199-2

Rather, M. A., Thenmozhi, A. J., Manivasagam, T., Bharathi, M. D., Essa, M. M., and Guillemin, G. J. (2018a). Neuroprotective role of asiatic acid in aluminium chloride induced rat model of Alzheimer's disease. Front. Biosci. - Scholar 10 (2), 262-275. doi: 10.2741/s514

Rather, M. A., Thenmozhi, A. J., Manivasagam, T., Nataraj, J., Essa, M. M., and Chidambaram, S. B. (2018b). Asiatic acid nullified aluminium toxicity in in vitro model of Alzheimer's disease. Front. Biosci. - Elite 10 (2), 287-299. doi: $10.2741 / \mathrm{e} 823$

Ratz-Lyko, A., Arct, J., and Pytkowska, K. (2016). Moisturizing and antiinflammatory properties of cosmetic formulations containing Centella asiatica extract. Indian J. Pharm. Sci. 78 (1), 27-33. doi: 10.4103/0250474X.180247

Rehman, K., and Akash, M. S. H. (2017). Mechanism of Generation of Oxidative Stress and Pathophysiology of Type 2 Diabetes Mellitus: How Are They Interlinked? J. Cell. Biochem. 118 (11), 3577-3585. doi: 10.1002/jcb.26097

Ren, L., Cao, Q. X., Zhai, F. R., Yang, S. Q., and Zhang, H. X. (2016). Asiatic acid exerts anticancer potential in human ovarian cancer cells via suppression of PI3K/Akt/mTOR signalling. Pharm. Biol. 54 (11), 2377-2382. doi: 10.3109/ 13880209.2016.1156709

Richards, D. A., Aronovitz, M. J., Calamaras, T. D., Tam, K., Martin, G. L., Liu, P., et al. (2019). Distinct Phenotypes Induced by Three Degrees of Transverse Aortic Constriction in Mice. Sci. Rep. 9 (1), 5844. doi: 10.1038/s41598-01942209-7

Riley, C. M., and Sciurba, F. C. (2019). Diagnosis and Outpatient Management of Chronic Obstructive Pulmonary Disease: A Review. JAMA - J. Am. Med. Assoc. 321 (8), 786-797. doi: 10.1001/jama.2019.0131

Rosdah, A. A., Lusiana, E., Reagan, M., Akib, A., Khairunnisa, F., and Husna, A. (2019). A preliminary study: Centella asiatica extract modulates acetylcholine in the heart. J. Phys.: Conf. Ser. 1246, 12048. doi: 10.1088/1742-6596/1246/1/012048

Saggu, R., Schumacher, T., Gerich, F., Rakers, C., Tai, K., Delekate, A., et al. (2016). Astroglial NF-kB contributes to white matter damage and cognitive impairment in a mouse model of vascular dementia. Acta Neuropathol. Commun. 4 (1), 76. doi: 10.1186/s40478-016-0350-3

Saltiel, A. R., and Olefsky, J. M. (2017). Inflammatory mechanisms linking obesity and metabolic disease. J. Clin. Invest. 127 (1), 1-4. doi: 10.1172/JCI92035

Sasmita, A. O., Ling, A. P. K., Voon, K. G. L., Koh, R. Y., and Wong, Y. P. (2018). Madecassoside activates anti-neuroinflammatory mechanisms by inhibiting lipopolysaccharide-induced microglial inflammation. Int. J. Mol. Med. 41 (5), 3033-3040. doi: 10.3892/ijmm.2018.3479

Savaris, R. F., Fuhrich, D. G., Duarte, R. V., Franik, S., and Ross, J. (2017). Antibiotic therapy for pelvic inflammatory disease. Cochrane Database Syst. Rev. 4 (4), CD010285. doi: 10.1002/14651858.CD010285.pub2

Sawatdee, S., Choochuay, K., Chanthorn, W., and Srichana, T. (2016). Evaluation of the topical spray containing Centella asiatica extract and its efficacy on excision wounds in rats. Acta Pharm. 66 (2), 233-244. doi: 10.1515/acph-20160018

Scott, D. L., Wolfe, F., and Huizinga, T. W. J. (2010). Rheumatoid arthritis. Lancet. 376 (9746), 1094-1108. doi: 10.1016/S0140-6736(10)60826-4

Selman, M., and Pardo, A. (2002). Idiopathic pulmonary fibrosis: an epithelial/ fibroblastic cross-talk disorder. Respir Res. 3 (1), 3. doi: 10.1186/rr175

Sh Ahmed, A., Taher, M., Mandal, U. K., Jaffri, J. M., Susanti, D., Mahmood, S., et al. (2019). Pharmacological properties of Centella asiatica hydrogel in accelerating wound healing in rabbits. BMC Complement. Altern. Med. 19 (1), 1-7. doi: 10.1186/s12906-019-2625-2

Shen, X., Guo, M., Yu, H., Liu, D., Lu, Z., and Lu, Y. (2019). Propionibacterium acnes related anti-inflammation and skin hydration activities of madecassoside, a 
pentacyclic triterpene saponin from Centella asiatica. Biosci. Biotechnol. Biochem. 83 (3), 561-568. doi: 10.1080/09168451.2018.1547627

Si, L., Xu, J., Yi, C., Xu, X., Ma, C., Yang, J., et al. (2015). Asiatic Acid Attenuates the Progression of Left Ventricular Hypertrophy and Heart Failure Induced by Pressure Overload by Inhibiting Myocardial Remodeling in Mice. J. Cardiovasc. Pharmacol. 66 (6), 558-568. doi: 10.1097/FJC.0000000000000304

Siddique, A.II, Mani, V., Arivalagan, S., Thomas, N. S., and Namasivayam, N. (2017). Asiatic acid attenuates pre-neoplastic lesions, oxidative stress, biotransforming enzymes and histopathological alterations in 1,2dimethylhydrazine-induced experimental rat colon carcinogenesis. Toxicol. Mech. Methods 27 (2), 136-150. doi: 10.1080/15376516.2016.1273422

Singh, B., and Rastogi, R. P. (1969). A reinvestigation of the triterpenes of Centella asiatica. Phytochemistry. 8 (5), 917-921. doi: 10.1016/S0031-9422(00)85884-7

Singh, B., and Rastogi, R. P. (1968). "Chemical examination of Centella asiatica linn-III”. Phytochemistry 7 (8), 1385-1393. doi: 10.1016/S0031-9422(00) $85642-3$

Singkhorn, S., Tantisira, M. H., Tanasawet, S., Hutamekalin, P., Wongtawatchai, T., and Sukketsiri, W. (2018). Induction of keratinocyte migration by ECa 233 is mediated through FAK/Akt, ERK, and p38 MAPK signaling. Phytother. Res. 32 (7), 1397-1403. doi: 10.1002/ptr.6075

Sirichoat, A., Chaijaroonkhanarak, W., Prachaney, P., Pannangrong, W., Leksomboon, R., Chaichun, A., et al. (2015). Effects of Asiatic acid on spatial working memory and cell proliferation in the adult rat hippocampus. Nutrients 7 (10), 8413-8423. doi: 10.3390/nu7105401

Smolen, J. S., Aletaha, D., and McInnes, I. B. (2016). Rheumatoid arthritis. Lancet. 388 (10055), 2023-2038. doi: 10.1016/S0140-6736(16)30173-8

Soll, A. H., Weinstein, W. M., Kurata, J., and McCarthy, D. (1991). Nonsteroidal anti-inflammatory drugs and peptic ulcer disease. Ann. Internal Med. 114 (4), 307-319. doi: 10.7326/0003-4819-114-4-307

Sonawane, V. K., Mahajan, U. B., Shinde, S. D., Chatterjee, S., Chaudhari, S. S., Bhangale, H. A., et al. (2018). A Chemosensitizer Drug: Disulfiram Prevents Doxorubicin-Induced Cardiac Dysfunction and Oxidative Stress in Rats. Cardiovasc. Toxicol. 18 (5), 459-470. doi: 10.1007/s12012-018-9458-y

Song, D., Jiang, X., Liu, Y., Sun, Y., Cao, S., and Zhang, Z. (2018). Asiaticoside attenuates cell growth inhibition and apoptosis induced by $A \beta 1-42$ via inhibiting the TLR4/NF- $\mathrm{KB}$ signaling pathway in human brain microvascular endothelial cells. Front. Pharmacol. 9, 28 (JAN). doi: 10.3389/fphar.2018.00028

Songvut, P., Chariyavilaskul, P., Tantisira, M. H., and Khemawoot, P. (2019). Safety and Pharmacokinetics of Standardized Extract of Centella asiatica (ECa 233) Capsules in Healthy Thai Volunteers: A Phase 1 Clinical Study. [Clinical Trial, Phase I; Journal Article] Planta Med. 85 (6), 483-490. doi: 10.1055/a0835-6671

Sorg, H., Tilkorn, D. J., Hager, S., Hauser, J., and Mirastschijski, U. (2017). Skin Wound Healing: An Update on the Current Knowledge and Concepts. Eur. Surg. Res. 58 (1-2), 81-94. doi: 10.1159/000454919

Stewart, C., Ralyea, C., and Lockwood, S. (2019). Ovarian Cancer: An Integrated Review. Semin. Oncol. Nurs. 35 (2), 151-156. doi: 10.1016/j.soncn.2019.02.001

Subaraja, M., and Vanisree, A. J. (2019). The novel phytocomponent asiaticosideD isolated from Centella asiatica exhibits monoamine oxidase-B inhibiting potential in the rotenone degenerated cerebral ganglions of Lumbricus terrestris. Phytomedicine 58, 152833. doi: 10.1016/j.phymed.2019.152833

Suetomi, T., Willeford, A., Brand, C. S., Cho, Y., Ross, R. S., and Miyamoto, S. (2018). Inflammation and NLRP3 Inflammasome Activation Initiated in Response to Pressure Overload by Ca2+/Calmodulin-Dependent Protein Kinase II $\delta$ Signaling in Cardiomyocytes Are Essential for Adverse Cardiac Remodeling. Circulation 138 (22), 2530-2544. doi: 10.1161/CIRCULATION AHA.118.034621

Sukketsiri, W., Tanasawet, S., Moolsap, F., Tantisira, M. H., Hutamekalin, P., and Tipmanee, V. (2019). ECa 233 suppresses LPS-induced proinflammatory responses in macrophages via suppressing ERK1/2, p38 MAPK and Akt pathways. Biol. Pharm. Bull. 42 (8), 1358-1365. doi: 10.1248/bpb.b19-00248

Sun, T., Liu, B., and Li, P. (2015). Nerve protective effect of asiaticoside against ischemia-hypoxia in cultured rat cortex neurons. Med. Sci. Monit. 21, 30363041. doi: 10.12659/MSM.894024

Tanaka, H., Yamashita, T., Yoneda, M., Takagi, S., and Miura, T. (2018). Characteristics of bone strength and metabolism in type 2 diabetic model Tsumura, Suzuki, Obese Diabetes mice. [Journal Article]. Bone Rep. 9, 74-83. doi: 10.1016/j.bonr.2018.07.004
Thannickal, V. J., Toews, G. B., White, E. S., Lynch III, J. P., and Martinez, F. J. (2004). Mechanisms of Pulmonary Fibrosis. Annu. Rev. Med. 55, 395-417. doi: 10.1146/annurev.med.55.091902.103810

Thong-Asa, W., Tilokskulchai, K., Chompoopong, S., and Tantisira, M. H. (2018). Effect of Centella asiatica on pathophysiology of mild chronic cerebral hypoperfusion in rats. Avicenna J. Phytomed. 8 (3), 210-226. doi: 10.22038/ ajp.2017.21164.1800

Tian, R., Zhu, Y., Yao, J., Meng, X., Wang, J., Xie, H., et al. (2017). NLRP3 participates in the regulation of EMT in bleomycin-induced pulmonary fibrosis. Exp. Cell Res. 357 (2), 328-334. doi: 10.1016/j.yexcr.2017.05.028

Tönnies, E., and Trushina, E. (2017). Oxidative Stress, Synaptic Dysfunction, and Alzheimer's Disease. J. Alzheimer's Dis. 57 (4), 1105-1121. doi: 10.3233/JAD161088

Viswanathan, G., Dan, V. M., Radhakrishnan, N., Nair, A. S., Rajendran Nair, A. P., and Baby, S. (2019). Protection of mouse brain from paracetamol-induced stress by Centella asiatica methanol extract. J. Ethnopharmacol. 236, 474-483. doi: 10.1016/j.jep.2019.03.017

Wang, Z., and Chesler, N. C. (2013). Pulmonary vascular mechanics: Important contributors to the increased right ventricular afterload of pulmonary hypertension. Exp. Physiol. 98 (8), 1267-1273. doi: 10.1113/expphysiol.2012.069096

Wang, T., Wei, Z., Dou, Y., Yang, Y., Leng, D., Kong, L., et al. (2015). Intestinal interleukin-10 mobilization as a contributor to the anti-arthritis effect of orally administered madecassoside: A unique action mode of saponin compounds with poor bioavailability. Biochem. Pharmacol. 94 (1), 30-38. doi: 10.1016/ j.bcp.2015.01.004

Wang, X. B., Wang, W., Zhu, X. C., Ye, W. J., Cai, H., Wu, P. L., et al. (2015). The potential of asiaticoside for TGF- $\beta 1 /$ Smad signaling inhibition in prevention and progression of hypoxia-induced pulmonary hypertension. Life Sci. 137, 56-64. doi: 10.1016/j.lfs.2015.07.016

Wang, W., Wu, L., Li, Q., Zhang, Z., Xu, L., Lin, C., et al. (2018). Madecassoside prevents acute liver failure in LPS/D-GalN-induced mice by inhibiting p38/ $\mathrm{NF}-\mathrm{\kappa B}$ and activating Nrf2/HO-1 signaling. Biomed. Pharmacother. 103, 1137-1145. doi: 10.1016/j.biopha.2018.04.162

Wang, X., Cai, X., Wang, W., Jin, Y., Chen, M., Huang, X., et al. (2018). Effect of asiaticoside on endothelial cells inhypoxia-induced pulmonary hypertension. Mol. Med. Rep. 17 (2), 2893-2900. doi: 10.3892/mmr.2017.8254

Wang, Q., Yao, L., Xu, K., Jin, H., Chen, K., Wang, Z., et al. (2019). Madecassoside inhibits estrogen deficiency-induced osteoporosis by suppressing RANKLinduced osteoclastogenesis. J. Cell. Mol. Med. 23 (1), 380-394. doi: 10.1111/ jcmm. 13942

Wannasarit, S., Puttarak, P., Kaewkroek, K., and Wiwattanapatapee, R. (2019). Strategies for Improving Healing of the Gastric Epithelium Using Oral Solid Dispersions Loaded with Pentacyclic Triterpene-Rich Centella Extract. AAPS PharmSciTech 20 (7), 277. doi: 10.1208/s12249-019-1488-7

Wei, L., Chen, Q., Guo, A., Fan, J., Wang, R., and Zhang, H. (2018). Asiatic acid attenuates CCl4-induced liver fibrosis in rats by regulating the PI3K/AKT/ mTOR and $\mathrm{Bcl}-2 / \mathrm{Bax}$ signaling pathways. Int. Immunopharmacol. 60, 1-8. doi: $10.1016 /$ j.intimp.2018.04.016

Welbat, J. U., Sirichoat, A., Chaijaroonkhanarak, W., Prachaney, P., Pannangrong, W., Pakdeechote, P., et al. (2016). Asiatic acid prevents the deleterious effects of valproic acid on cognition and hippocampal cell proliferation and survival. Nutrients 8 (5), 1-11. doi: 10.3390/nu8050303

Welbat, J. U., Chaisawang, P., Pannangrong, W., and Wigmore, P. (2018). Neuroprotective properties of asiatic acid against 5-fluorouracil chemotherapy in the hippocampus in an adult rat model. Nutrients 10 (8), 1053. doi: 10.3390/ nu10081053

Wong, J. H., Muthuraju, S., Reza, F., Senik, M. H., Zhang, J., Mohd Yusuf Yeo, N. A. B., et al. (2019). Differential expression of entorhinal cortex and hippocampal subfields $\alpha$-amino-3-hydroxy-5-methyl-4-isoxazolepropionic acid (AMPA) and N-methyl-D-aspartate (NMDA) receptors enhanced learning and memory of rats following administration of Centella asiatica. Biomed. Pharmacother. 110, 168-180. doi: 10.1016/j.biopha.2018.11.044

World Health Organisation (2013). "Obesity and overweight. Fact sheet $\mathrm{N}^{\circ} 311$," in Fact Sheet N. Available at: http://www.who.int/mediacentre/factsheets/ fs311/en/index.html.

Wu, T., Geng, J., Guo, W., Gao, J., and Zhu, X. (2017). Asiatic acid inhibits lung cancer cell growth in vitro and in vivo by destroying mitochondria. Acta Pharm. Sin. B 7 (1), 65-72. doi: 10.1016/j.apsb.2016.04.003 
Xiao, W., Jiang, W., Li, K., Hu, Y., Li, S., Zhou, L., et al. (2017). Protective effect of asiatic acid in an experimental cerulein-induced model of acute pancreatitis in mice. Am. J. Trans. Res. 9 (8), 3842-3852.

Xu, X., Wang, Y., Wei, Z., Wei, W., Zhao, P., Tong, B., et al. (2017). Madecassic acid, the contributor to the anti-colitis effect of madecassoside, enhances the shift of Th17 toward Treg cells via the PPAR $\gamma /$ AMPK/ACC1 pathway. Cell Death Dis. 8 (3), e2723. doi: 10.1038/cddis.2017.150

Yang, B., Xu, Y., Hu, Y., Luo, Y., Lu, X., Tsui, C. K., et al. (2016). Madecassic Acid protects against hypoxia-induced oxidative stress in retinal microvascular endothelial cells via ROS-mediated endoplasmic reticulum stress. Biomed. Pharmacother. 84, 845-852. doi: 10.1016/j.biopha.2016.10.015

Yao, C. H., Yeh, J. Y., Chen, Y. S., Li, M. H., and Huang, C. H. (2017). Woundhealing effect of electrospun gelatin nanofibres containing Centella asiatica extract in a rat model. J. Tissue Eng. Regen. Med. 11 (3), 905-915. doi: 10.1002/ term.1992

Yin, M. C., Lin, M. C., Mong, M. C., and Lin, C. Y. (2012). Bioavailability, distribution, and antioxidative effects of selected triterpenes in mice. J. Agric. Food Chem. 60 (31), 7697-7701. doi: 10.1021/jf302529x

Yu, W. G., Shen, Y., Wu, J. Z., Gao, Y. B., and Zhang, L. X. (2018). Madecassoside impedes invasion of rheumatoid fibroblast-like synoviocyte from adjuvant arthritis rats via inhibition of NF- $\mathrm{KB}$-mediated matrix metalloproteinase-13 expression. Chin. J. Natural Medicines 16 (5), 330-338. doi: 10.1016/S18755364(18)30064-5

Yuan, Y., Zhang, H., Sun, F., Sun, S., Zhu, Z., and Chai, Y. (2015). Biopharmaceutical and pharmacokinetic characterization of asiatic acid in Centella asiatica as determined by a sensitive and robust HPLC-MS method. J. Ethnopharmacol. 163, 31-38. doi: 10.1016/j.jep.2015.01.006

Yuan, Z., Yidan, Z., Jian, Z., Xiangiian, Z., and Guofeng, Y. (2020). Molecular mechanism of Autophagy: Its role in the therapy of Alzheimer's disease. [published online ahead of print, 2020 Jan 14]. Curr. Neuropharmacol. doi: $10.2174 / 1570159 \times 18666200114163636$

Yunianto, I., Das, S., and Mat, N. M. (2010). Antispermatogenic and antifertility effect of Pegaga (Centella asiatica L) on the testis of male Sprague-Dawley rats. [Journal Article; Research Support, Non-U.S. Gov't] Clin. Ter. 161 (3), 235-239.
Yuyun, X., Xi, C., Qing, Y., Lin, X., Ke, R., and Bingwei, S. (2018). Asiatic acid attenuates lipopolysaccharide-induced injury by suppressing activation of the Notch signaling pathway. Oncotarget 9 (19), 15036-15046. doi: 10.18632/ oncotarget. 24542

Zhang, C., Xu, J. H., Liu, T., and Cui, H. (2011). [Clinical significance of signal transduction and activators of transcription 3, E-cadherin and vimentin in colon cancer]. Zhonghua Wei Chang Wai Ke Za Zhi= Chin. J. Gastrointest. Surg. 14 (3), 202-205.

Zheng, H. M., Choi, M. J., Kim, J. M., Cha, K. H., Lee, K. W., Park, Y. H., et al. (2016a). Centella asiatica Leaf Extract Protects Against Indomethacin-Induced Gastric Mucosal Injury in Rats. J. Med. Food 19 (1), 38-46. doi: 10.1089/ jmf.2015.3464

Zheng, H. M., Choi, M. J., Kim, J. M., Lee, K. W., Park, Y. H., and Lee, D. H. (2016b). In vitro and in vivo anti-Helicobacter pylori activities of Centella asiatica leaf extract. Prev. Nutr. Food Sci. 21 (3), 197-201. doi: 10.3746/ pnf.2016.21.3.197

Zheng, Y., Ley, S. H., and Hu, F. B. (2018). Global aetiology and epidemiology of type 2 diabetes mellitus and its complications. Nat. Rev. Endocrinol. 14 (2), 8898. doi: 10.1038/nrendo.2017.151

Zou, Z., Liu, W., Cao, L., Liu, Y., He, T., Peng, S., et al. (2020). Advances in the occurrence and biotherapy of osteoporosis. [published online ahead of print, 2020 Jul 6] Biochem. Soc. Trans. doi: 10.1042/BST20200005

Conflict of Interest: The authors declare that the research was conducted in the absence of any commercial or financial relationships that could be construed as a potential conflict of interest.

Copyright (c) 2020 Sun, Wu, Wu, Zhang, Qin, Hayashi, Kudo, Gao and Liu. This is an open-access article distributed under the terms of the Creative Commons Attribution License (CC BY). The use, distribution or reproduction in other forums is permitted, provided the original author(s) and the copyright owner(s) are credited and that the original publication in this journal is cited, in accordance with accepted academic practice. No use, distribution or reproduction is permitted which does not comply with these terms. 